\title{
Electrodeposition of atmosphere-sensitive ternary sodium transition metal oxide films for sodium-based electrochemical energy storage
}

Arghya Patra ${ }^{1,2,3}$, Jerome Davis III,3, Saran Pidaparthy ${ }^{1,2}$, Manohar H. Karigerasi ${ }^{1,2}$, Beniamin Zahiri $^{1,2,3}$, Ashish A. Kulkarni ${ }^{1,2,3}$, Michael A. Caple ${ }^{1,2,3}$, Daniel P. Shoemaker ${ }^{1,2}$, Jian Min Zuo ${ }^{1,2}$, Paul V. Braun ${ }^{1,2,3,4^{*}}$

${ }^{1}$ Department of Materials Science and Engineering, University of Illinois at Urbana-Champaign, Illinois 61801, USA

${ }^{2}$ Materials Research Laboratory, University of Illinois at Urbana-Champaign, Illinois 61801, USA

${ }^{3}$ Beckman Institute for Advanced Science and Technology, University of Illinois at Urbana-

Champaign, Illinois 61801, USA

${ }^{4}$ Department of Chemistry, University of Illinois at Urbana-Champaign, Illinois 61801, USA

${ }^{*}$ Paul V. Braun

Email: pbraun@illinois.edu

\section{Abstract}

We introduce an intermediate temperature $\left(350^{\circ} \mathrm{C}\right)$ dry molten sodium hydroxide mediated binder-free electrodeposition process to grow the previously electrochemically inaccessible air and moisture sensitive layered sodium transition metal oxides, $\mathrm{Na}_{\mathbf{x}} \mathrm{MO}_{2}$ $(\mathrm{M}=\mathrm{Co}, \mathrm{Mn}, \mathrm{Ni}, \mathrm{Fe})$, in both thin and thick film form, compounds which are conventionally synthesized in powder form by solid state reactions at temperatures $\geq 700^{\circ} \mathrm{C}$. As a key motivation for this work, several of these oxides are of interest as cathode materials for emerging sodium-ion-based electrochemical energy storage systems. Despite the low synthesis temperature and short reaction times, our electrodeposited oxides retain the key structural and electrochemical performance observed in high temperature bulk synthesized materials. We demonstrate that tens of microns thick $>75 \%$ dense $\mathrm{Na}_{x} \mathrm{CoO}_{2}$ and $\mathrm{Na}_{\mathrm{x}} \mathrm{MnO}_{2}$ can be deposited in under an hour. When used as cathodes for sodium-ion batteries these materials exhibit near theoretical gravimetric capacities, chemical diffusion coefficients of $\mathrm{Na}^{+}$ions $\left(\sim 10^{-12} \mathrm{~cm}^{2} \mathrm{~s}^{-1}\right)$, and high reversible areal capacities in the range 0.25-0.76 $\mathrm{mAhcm}^{-2}$, values significantly higher than those reported for binder-free sodium cathodes deposited by other techniques. The method described here resolves longstanding intrinsic challenges associated with traditional aqueous solution-based electrodeposition of ceramic oxides and opens a general solution chemistry approach for electrochemical processing of hitherto unexplored air and moisture sensitive high valent multinary structures with extended frameworks. 


\section{Main Text}

\section{Introduction}

Electrochemical synthesis of materials has contributed to significant breakthroughs in materials processing by replacing high temperature, cost and energy intensive pyrometallurgical processes (1). Noteworthy examples include aluminum extraction by Bayer's process (2), electrowinning of copper (3), titanium extraction through the Kroll process (4), electrolytic production of steel (5), and electrochemical synthesis of cement (6). Additional advantages of electrochemical synthesis include controllable access to metastable polymorphs (7), prevention of crystallite coarsening, and generation of asymmetric, highly oriented structures (8). Specific to the work discussed here on transition metal oxides for electrochemical energy storage, electrodeposition allows direct thermodynamic and kinetic control of the phase formation along with the ability to conformally deposit on topologically complex structures resulting in improved electron and ion transport kinetics (9). Even though electrodeposition as a technology is well developed for reduction of elements and alloys, studies on multicomponent systems grown by electrolytic oxidation are sparse. Finally, synthesis of materials directly using electrons as the energy packet, provides potential of significant reductions in greenhouse gas emissions and enhanced thermodynamic efficiencies (10).

We focus on materials for sodium ion (Na-ion) batteries due to their potential cost advantages over lithium-ion systems, and the equitable distribution of raw materials required for the synthesis of the cathodes relative to lithium-based systems (11). Of particular interest for $\mathrm{Na}$-ion battery cathodes is $\mathrm{O} 3$ type layered $\mathrm{NaMO}_{2}(\mathrm{M}=\mathrm{Co}, \mathrm{Mn}, \mathrm{Ni}$, $\mathrm{Fe}$ ) with an alpha $\mathrm{NaFeO}_{2}$ type crystal structure and octahedrally coordinated transition metal ion. Along with electrochemical energy storage applications (12), this class of oxides has also been studied for its catalytic (13) and superconducting (14) properties. Fabrication of $\mathrm{NaMO}_{2}$-based battery cathodes involves first high temperature $\left(>700^{\circ} \mathrm{C}\right)$ synthesis of $\mathrm{NaMO}_{2}$ for over 24 hours, followed by grinding, mixing with binders and additives, and slurry casting. Throughout the process, water must be rigorously excluded. While vapor-phase deposition of $\mathrm{Na}$-ion cathodes by methods including pulsed laser deposition, and RF and magnetron sputtering has been attempted, deposition of polytypes of $\mathrm{Na}_{x} \mathrm{CoO}_{2}$ (15-18), alpha $\mathrm{Na}_{x} \mathrm{MnO}_{2}$ (19), and polyanion compounds (20) has faced processing challenges, only the first of which is maintaining $\mathrm{Na}$ stoichiometry under 
vacuum during growth on a substrate heated to around $700^{\circ} \mathrm{C}$. Additionally, the vaporphase methods have been limited to cathodes with thicknesses of $\leq 750 \mathrm{~nm}$ and growth rates of only tens of $\mathrm{nm} / \mathrm{hr}$. As a result, the areal capacities are only a few $\mu A \mathrm{hcm}^{-2}$ even at modest discharge currents of order $10 \mu \mathrm{Acm}^{-2}$. The direct electrochemical synthesis of thick layered sodium transition metal oxides (STMOs) at reasonable growth rates and temperatures would overcome the abovementioned challenges and serve as a potential starting point for the scalable manufacturing for Na-ion cathodes. As we will show, such electrochemically grown cathodes also have higher volumetric and gravimetric capacities than slurry-based electrodes due to the absence of binder and conductive additives.

In early work, most ceramic oxides, including binary (21-23) and ternary oxides (2427) were formed via aqueous electrodeposition. These systems were generally limited to thinner layers $(\leq 5 \mu \mathrm{m})$, exhibited slow growth rates ( $\mu \mathrm{m} / \mathrm{day})$, and poor crystallinity. An annealing step is often needed to oxygenate and crystallize the deposit. The general mechanism for anodic electrolytic deposition of ceramic oxides (28) involves the complexation of a transition metal ion in an alkaline solution as stable hydroxo-aquo complexes of the type $\mathrm{M}^{(\mathrm{m}+)}(\mathrm{OH})_{x}\left(\mathrm{H}_{2} \mathrm{O}\right)_{y}(\mathrm{~m}=2-3)$ (details depend on the transition metal ion concentration, charge on the transition metal ion center, $\mathrm{pH}$, and temperature (2931)). During the anodic oxidation step, $\mathrm{M}^{\mathrm{m}+}$ is electrochemically oxidized and precipitates as a higher valent oxide and/or proton intercalated oxide. The poor kinetics of the reaction and quality of electrodeposits can be traced back to the choice of water as the solvent, the low temperature of synthesis (room temperature to $80^{\circ} \mathrm{C}$ ), and the low hydrolysis ratio (i.e., $\mathrm{OH}^{-} / \mathrm{M}^{\mathrm{m}+}=3-5$ at $\mathrm{pH} 14$ for low transition metal concentrations). Synthesis temperatures of prior electrodeposited oxide/oxyhydroxides by anodic electrolytic deposition and equivalent solid-state synthesis are summarized in Fig. S1A. A high hydrolysis ratio $(>75)$ (S1B) and high temperature of deposition $\left(>250^{\circ} \mathrm{C}\right)$ (S1C) synergistically kinetically benefit the growth of thicker (> $10 \mu \mathrm{m}$ ) electrodeposits. Moreover, since the $\mathrm{O} 3$ and O'3 polytypes of the STMOs most interesting for energy storage applications are air and moisture sensitive (32), aqueous electrodeposition cannot be employed to grow these class of materials.

Here we report a dry molten sodium hydroxide-based solvent mediated electrodeposition of high quality thick STMOs with controlled crystallography and phase. By using dry hydroxide salts, we overcome the intrinsic limitations imposed by the 
inclusion of water in the solvent, and broaden the temperature range of the growth conditions. Oxides of transition metals $\left(\mathrm{Co}_{3} \mathrm{O}_{4}, \mathrm{Mn}_{3} \mathrm{O}_{4}, \mathrm{Fe}_{3} \mathrm{O}_{4}, \mathrm{Ni}(\mathrm{OH})_{2}\right)$ are first solvated as stable hydroxo complexes in molten $\mathrm{NaOH}$ at $350^{\circ} \mathrm{C}$. In comparison to water based anodic electrodeposition, here, electrodeposition is conducted at an extremely high hydrolysis ratio $\left(\mathrm{OH}^{-} / \mathrm{M}^{2+}=300: 1\right)$ and high $\mathrm{pH}\left(\mathrm{pH}_{2} \mathrm{O}=10\right.$ in Lux flood scale $)$ and at an elevated temperature of $350^{\circ} \mathrm{C}$. The combination of these factors improves the kinetics of the deposition rate limiting base catalyzed oxolation (inorganic $S_{N} 2$ ) process, due to the extremely high nucleophile concentration $\left[\mathrm{OH}^{-}\right]$, catalyzed by the "base" $\left[\mathrm{OH}^{-}\right]$, and removal of the leaving group $\mathrm{H}_{2} \mathrm{O}$ from the bath (as vapor at $\left.350^{\circ} \mathrm{C}\right)(31)$. We specifically demonstrate the direct electrochemical deposition of various thick film $(>10 \mu \mathrm{m})$ thermodynamically and kinetically controlled highly crystalline STMOs polymorphs. Fig. 1 outlines the general electrodeposition scheme. We explore the effects of the applied electrode potential, basicity of the hydroxide solvent medium, transition metal precursor concentration, and temperature of synthesis on the resulting phase assemblage, phase distribution, and electrochemical performance of the electrodeposited $\mathrm{Na}-\mathrm{M}-\mathrm{O}$ phases across various transition metal chemistries.

\section{Results}

\section{Pourbaix diagrams and cyclic voltammetry of the Na-M-O-H systems}

Fig. 2 compares the Pourbaix diagrams for the investigated Na-M-O chemistries, corresponding cyclic voltammetry curves and the suggested electrodeposition pathways. Pourbaix diagrams are constructed as detailed in SI 1 and Ref. (33). Cyclic voltammetry was conducted with the respective transition metal precursor at a molar ratio of $300: 1$ $\left(\mathrm{Na}^{+}: \mathrm{M}^{2+}\right)$ in molten $\mathrm{NaOH}$ solvent at $350^{\circ} \mathrm{C}$. The solvent medium follows a Lux Flood acid base concept where the $\mathrm{pH}_{2} \mathrm{O}$ dictates the solvent basicity (34). The self-dissociation constant for the reaction $2 \mathrm{OH}^{-} \rightleftharpoons \mathrm{H}_{2} \mathrm{O}+\mathrm{O}^{2-}$ is $10^{-10}$ at $350^{\circ} \mathrm{C}(35-37)$ and the solvent $\mathrm{pH}_{2} \mathrm{O}$ is assumed to be $\simeq 10$ for all experiments at $350^{\circ} \mathrm{C}$. Electrolytic deposition of the respective STMOs is a function of a) the chemical stability of the transition metal hydroxo complex in +2 state, b) the oxidation potential of the transition metal hydroxo complex in comparison to the electrolyte decomposition potential, and c) the chemical stability of the STMO in the solvent at the synthesis temperature. For a successful electrolytic deposition, the complex must be chemically stable, with the oxidation potential of the $\mathrm{M}^{2+} \mid \mathrm{M}^{3+}$ being less than that of the electrolyte decomposition and the electrodeposited STMO must be 
chemically stable in the electrolyte. The Pourbaix diagrams provide a qualitative representation of the abovementioned factors and the experimental CV curves corroborate the main inferences from the Pourbaix diagrams. We choose the mixed valent oxides $\mathrm{M}_{3} \mathrm{O}_{4}(\mathrm{M}=\mathrm{Co}, \mathrm{Mn}, \mathrm{Fe})$ as the precursor for electrodeposition, at a concentration less than the solubility limit of $\mathrm{M}_{3} \mathrm{O}_{4}$ in molten $\mathrm{NaOH}$ at $350^{\circ} \mathrm{C} . \mathrm{M}_{3} \mathrm{O}_{4}$ is composed of equimolar quantities of $\mathrm{MO}$ and $\mathrm{M}_{2} \mathrm{O}_{3}$ with $\mathrm{M}^{\mathrm{x}}$ formal oxidation states of +2 and +3 , respectively. A stable $\mathrm{M}^{2+}$ hydroxo complex from $\mathrm{MO}$ can be electrochemically oxidized to $\mathrm{M}_{3} \mathrm{O}_{4}$ or $\mathrm{NaMO}_{2}$ based on the basicity of the solvent and temperature. We aim to electrodeposit $\mathrm{M}_{3} \mathrm{O}_{4}$-free $\mathrm{NaMO}_{2}$. By using $\mathrm{M}_{3} \mathrm{O}_{4}$ as the precursor, at a concentration below its solubility limit $\mathrm{NaOH}$, enables deposition of $\mathrm{M}_{3} \mathrm{O}_{4}$-free $\mathrm{NaMO}_{2}$. Basically, should any $\mathrm{M}_{3} \mathrm{O}_{4}$ be electrodeposited, it remains soluble in the bath, and will dissolve in the solvent.

Amongst the different Na-M-O systems, only Pourbaix diagrams of Na-Co-O (Fig. 2A) and Na-Mn-O (Fig. 2D) show the presence of a thermodynamic zone (light yellow) where complexes of the type $\mathrm{Co}(\mathrm{OH})_{4}{ }^{2-}$ and $\mathrm{Mn}(\mathrm{OH})_{4}{ }^{2-}$ with a formal oxidation state of +2 can be electrochemically oxidized to +3 in zone II before electrochemical decomposition of the electrolyte. CV during the first cycle for the Na-Co-O system (Fig. 2B), shows the electrochemical oxidation of $\mathrm{Co}^{2+} \mid \mathrm{Co}^{3+}$ at $0.45 \mathrm{~V}$ (vs. Mo) (denoted by * in Fig. 2B) and for $\mathrm{Na}-\mathrm{Mn}-\mathrm{O}$ shows the oxidation of $\mathrm{Mn}^{2+} \mid \mathrm{Mn}^{3+}$ (denoted by * in Fig. 2D) at $0.86 \mathrm{~V}$ (vs. W). For the subsequent cycle, the electrodeposited material in the +3 state undergoes further partial oxidation for $\mathrm{Co}^{3+} \mid \mathrm{Co}^{4+}$ at $0.91 \mathrm{~V}$ (vs. Mo) and $\mathrm{Mn}^{3+} \mid \mathrm{Mn}^{4+}$ at $1.01 \mathrm{~V}$ (vs. W) (denoted by in Fig. 2D). For all the systems, the first cycle shows the oxidation and partial/complete passivation of the substrate by $\mathrm{NiO}$ (marked by $\downarrow$ ). Complete passivation is defined by a very low amplitude of the $\mathrm{Ni} \mid \mathrm{Ni}^{2+}$ redox current (corresponding to the oxidation of nickel to nickel oxide) during the second CV cycle at the same potential as where the nickel is oxidized in the first cycle. The mechanism of deposition for $\mathrm{Na}_{\mathrm{x}} \mathrm{CoO}_{2}$ (Fig. 2C) and $\mathrm{Na}_{x} \mathrm{MnO}_{2}$ (Fig. 2F) is hypothesized as an electrochemically initiated, fluxassisted electrocrystallization reaction where the electrochemical oxidation (EO) of the transition metal hydroxo complex (from II to III) triggers a base catalyzed oxolation reaction (31) producing precipitation $(P)$ of product insoluble in the solvent electrolyte.

The Pourbaix diagram for the Na-Ni-O system (Fig. 2G) indicates that $\mathrm{Ni}(\mathrm{OH})_{4}{ }^{2-}$ cannot be electrochemically oxidized to +3 before electrochemical decomposition of the 
electrolyte. CV (Fig. 2H) further corroborates that the $\mathrm{Ni}^{2+}$ complex cannot be electrochemically oxidized to $\mathrm{Ni}^{3+}\left(\mathrm{Na}_{x} \mathrm{NiO}_{2}\right)$ in molten $\mathrm{NaOH}$ and there is no change in cycle 1 and cycle 2 . Thus, it is not possible to electrolytically deposit $\mathrm{Na}_{x} \mathrm{NiO}_{2}$ under the adopted solvent conditions. Similar observations have been found in electrolysis of $\mathrm{Ni}(\mathrm{OH})_{2}$ in a $\mathrm{NaOH}-\mathrm{KOH}$ solvent at $227^{\circ} \mathrm{C}(38)$. As a result, a different approach was adopted for deposition of $\mathrm{Na}-\mathrm{Ni}-\mathrm{O}$ as outlined in Fig. 2I. A pulsed anodic potential of 1.20 V (vs. W) was applied to electrochemically decompose (marked as ED in figure) the electrolyte, generating $\mathrm{O}_{2}\left(\mathrm{OH}^{-} \rightarrow \mathrm{H}_{2} \mathrm{O}+\mathrm{O}_{2}\right)$ near the working electrode. The $\mathrm{O}_{2}$ subsequently chemically oxidizes and precipitates the $\mathrm{Ni}^{2+}$ complex as $\mathrm{Na}_{x} \mathrm{NiO}_{2}$ on the working electrode.

The $\mathrm{Fe}^{2+}$ hydroxo complex is chemically unstable in dry molten $\mathrm{NaOH}$ at $350^{\circ} \mathrm{C}$ and thus is chemically oxidized to the precipitate $\mathrm{Na}_{x} \mathrm{Fe}_{\mathrm{y}} \mathrm{O}_{z}$ in this solvent. This is corroborated by the Pourbaix diagram (Fig. $\mathbf{2} \mathbf{J}$ ), which shows a very narrow stability domain for $\mathrm{FeO}$ in a highly basic solvent and a wide domain for $\mathrm{NaFeO}_{2}$. Chemical oxidation of the $\mathrm{Fe}$ (complex) in molten $\mathrm{NaOH}$ at $350^{\circ} \mathrm{C}$ is further supported by CV (Fig. 2K) which shows no stable $\mathrm{Fe}^{2+} \mid \mathrm{Fe}^{3+}$ redox in the solution after addition of the $\mathrm{Fe}_{3} \mathrm{O}_{4}$ precursor. As we will discuss at greater length electrodepositing from $\mathrm{Na}-\mathrm{Fe}-\mathrm{O}$ system required a different strategy based on controlled addition of $\mathrm{CsOH}$.

\section{Electrodeposition from Na-Co-O system}

Fig. 3A shows the X-ray diffractogram (XRD) of sodium cobalt oxide (SCO) electrodeposited at $0.6 \mathrm{~V}$ (vs. Mo) from $2.0 \mathrm{w} / \mathrm{w} \% \mathrm{Co}_{3} \mathrm{O}_{4}$ in $\mathrm{NaOH}$ at $350^{\circ} \mathrm{C}$. The aselectrodeposited material contains both $\mathrm{O} 3$ (major, 97\%) and O'3 (minor, 3\%) phases. O3 is indexed in a rhombohedral system with space group $R \overline{3} \mathrm{~m}$ and $\mathrm{O}^{\prime} 3$ is indexed in a monoclinic system with space group $\mathrm{C} 2 / \mathrm{m}$ (Table S3A). No $\mathrm{Co}_{3} \mathrm{O}_{4}$ is found. ICP measurements (Table S4A) show the stoichiometry to be $\mathrm{Na}_{0.98} \mathrm{CoO}_{2}$. The crystal structure of this $\mathrm{O} 3 \mathrm{SCO}$ is visualized using Vesta(39) and presented in Fig. 3B. The refined unit cell parameters $(a=b=2.8855(5) \AA, c=15.6087(9) \AA)$ closely match those reported for solid state synthesis (40-42). Fig. 3C shows the surface morphology of electrodeposited SCO. Electrodeposited SCO grows as interpenetrating hexagonal platelets (Fig. 3E, and Fig. 3F) with a (003) plane (green), bounded by Na ion conducting surface terminating (104) (pink), (110) planes (light blue) (Fig. 3D). The platelet type 
surface morphology has been predicted earlier for $\mathrm{O} 3 \mathrm{LiCoO}_{2}$ (43) prepared under synthesis conditions with high oxygen chemical potential (similar to that of $\mathrm{OH}^{-}$in a molten hydroxide flux). Cross-sectional analysis of the sample (Fig. 3E) show electrodeposits can be grown to $\simeq 300 \mu \mathrm{m}$ thick in 2 hours. To understand the physical distribution of the $\mathrm{O} 3$ and O' 3 phases, a platelet from this sample is analyzed with a $5 \mathrm{~nm}$ nanobeam via scanning electron nanobeam diffraction (SEND) over a $500 \mathrm{~nm} \times 500 \mathrm{~nm}$ area across the edge of the platelet (shown in Fig. 3G). The phase map of this area (Fig. $\mathbf{3 H}$ ) shows the central major part of the platelet is $\mathrm{O} 3$ and a small fraction of $\mathrm{O}^{\prime} 3$ is formed at the edge of the platelet ( 60-120 nm). Diffraction patterns acquired from the center (light brown square, Fig. 3I), middle (deep brown square, Fig. 3J) and edge (blue square, Fig. 3K) of the platelet show a gradual transition of O3 (blue dotted) to O'3 (dark green dotted) near the edge, with the phase fraction of O'3 increasing markedly near the edge. Diffraction patterns are indexed with a [001] zone axis and the unit cell parameters used in the analysis of the diffraction patterns are listed in Fig. S3A. This observation can be explained from the $\mathrm{Na}-\mathrm{Co}-\mathrm{O}$ phase diagram (44)(45) where $\mathrm{O} 3 \mathrm{NaCoO}_{2}$ occurs as a line compound and a small off-stoichiometry leads to the formation of $\mathrm{O}^{\prime} 3(0.83<x<0.99)$ in $\mathrm{Na}_{\mathrm{x}} \mathrm{CoO}_{2}$. The appearance of trace amounts O'3 at the edge of the platelet is hypothesized as a result of concomitant charging (desodiation) of the electrodeposited $\mathrm{Na}_{0.98} \mathrm{CoO}_{2}$ during deposition. This appears predominantly at the edges of platelet as an intraparticle phase separation occurs from $\mathrm{O} 3$ to $\mathrm{O}^{\prime} 3$. We note a two-hour hold in the electrolyte postdeposition chemically converts the trace O'3 to $\mathrm{O} 3$, resulting platelets which are homogeneous in phase (Fig. S3B \& Fig. S3C) and chemical composition (Fig. S3D).

Via XRD and $\mathrm{Na}$ half-cell electrochemical studies, the effect of precursor $\left(\mathrm{Co}_{3} \mathrm{O}_{4}\right)$ concentration ( $\mathrm{Na}^{+}: \mathrm{Co}^{2+}$ molar ratio) and applied pulse peak potential during plating (Fig. 3M) was investigated. A unique feature of the electrodeposition of layered STMOS is the electrochemical oxidation induced intraparticle phase heterogeneity and concurrent relaxation of the particle due to back-sodiation by the molten sodium hydroxide solvent. Here we demonstrate two ways to capture and identify the state of desodiation/phase heterogeneity of the as-electrodeposited phase assemblage by ex-situ XRD (indicated by $\Delta$ ) and corroborate the measurements with a complementary measurement of the equilibrated open circuit voltage in a $\mathrm{Na}$ half-cell (indicated by $\boldsymbol{\nabla}$ ). Agreement of the two methods by coincidence of two triangles takes the appearance of a star in the graph. OCV 
in an equilibrated $\mathrm{Na}$ half-cell are particularly useful to indicate the phase assemblage (single phase solid solution or biphasic mixture) as illustrated in detail in Fig. S4. CV measurements at the respective precursor concentrations chosen were collected (Fig. $3 L$ ). The peaks which we ascribe to the transition metal redox, are only present when the transition metal precursors are present. Cyclic voltammograms conducted in pure molten $\mathrm{NaOH}$ (black line) does not show any of the redox peaks (Fig. $3 \mathrm{~L}$ ). The $\mathrm{Co}^{2+} \mid \mathrm{Co}^{3+}$ redox is a function of precursor activity/concentration, ranging from $0.60 \mathrm{~V}$ (vs. Mo) at $0.2 \mathrm{w} / \mathrm{w} \%$ $\mathrm{Co}_{3} \mathrm{O}_{4}$ to $0.45 \mathrm{~V}$ (vs. Mo) at $2.0 \mathrm{w} / \mathrm{w} \% \mathrm{Co}_{3} \mathrm{O}_{4}$, beyond which the redox potential becomes lower due to the higher cobalt activity/concentration. At a high precursor concentration (2.0-7.0 w/w\%) and low overpotential $(50-250 \mathrm{mV})$, we observe the growth of O3. Increasing the applied voltage results in formation of a $\mathrm{O} 3$ and O'3 phase mixture. At high overpotentials $(450-550 \mathrm{mV})$ and low precursor concentrations $(0.2-2.0 \mathrm{w} / \mathrm{w} \%)$, there is presence of $\mathrm{P}^{\prime} 3$ phase. The observed phase behavior can be rationalized as follows. Layered $\mathrm{O} 3 \mathrm{Na}_{x} \mathrm{CoO}_{2}$ undergoes electrochemical transformation in the order $\mathrm{O} 3 \rightarrow \mathrm{O}$ '3 $\rightarrow \mathrm{P}^{\prime} 3(44,46,47)$ as the voltage is increased and sodium is extracted. Thus, an increase in the applied voltage first results in an $\mathrm{O} 3$ and $\mathrm{O} 3$ phase mixture. Finally, at high overpotentials both the $\mathrm{O} 3$ and O'3 phases form, and some O'3 converts to P'3. Thermal annealing of the as-electrodeposited $\mathrm{O} 3 \mathrm{Na}_{0.98} \mathrm{CoO}_{2}$ to $900^{\circ} \mathrm{C}$ and quenching the resultant phase arrests the high temperature P2 polymorph (Fig. S5), thus enabling access to both electrochemically important polytypes (O3 and $\mathrm{P} 2)$.

\section{Electrodeposition from $\mathrm{Na}-\mathrm{Mn}-\mathrm{O}$ system}

Na-Mn-O systems are electrodeposited at a pulsed voltage with a peak potential of $0.97 \mathrm{~V}$ vs. $\mathrm{W}$ for 2 hours at $350{ }^{\circ} \mathrm{C}$ from a bath consisting of $3.04 \mathrm{~g}$ of $\mathrm{Mn}_{3} \mathrm{O}_{4}$ in $160 \mathrm{~g}$ $\mathrm{NaOH}\left(\mathrm{Na}^{+}: \mathrm{Mn}^{2+} 300: 1\right)$. The resulting electrodeposit is composed of O'3 $\alpha^{\prime} \mathrm{Na}_{1.3} \mathrm{MnO}_{2+x}$ (94.56\%), $\beta \mathrm{NaMnO}_{2}$ (1.99\%) and $\mathrm{Cmcm} \mathrm{Na} .67 \mathrm{MnO}_{2}$ (3.45\%) (Fig. 4A). ICP measurements (Table S4B) show the $\mathrm{Na}$ to $\mathrm{Mn}$ molar ratio to be 1.3:1.0. Assuming the remainder is oxygen, the stoichiometry of this sodium excess structure is $\mathrm{Na}_{1.3} \mathrm{MnO}_{2+\mathrm{x}}$. O'3 (a') $\mathrm{Na}_{1.3} \mathrm{MnO}_{2+x}$ is indexed in a monoclinic system with space group $\mathrm{C} 2 / \mathrm{m}$ with unit cell parameters $\left(a=5.6777(6) \AA, b=2.8571(6) \AA, c=5.7597(9) \AA, \beta=113.06^{\circ}\right.$ ) (Table S3B) close to those reported for high temperature synthesis of $\alpha^{\prime} \mathrm{NaMnO}_{2}(48-50)$. Synthesis diagrams constructed from solid-state reactions do not show presence of $\alpha^{\prime} \mathrm{Na}_{1} \mathrm{MnO}_{2}$ or $\beta \mathrm{Na}_{1} \mathrm{MnO}_{2}$ below $600{ }^{\circ} \mathrm{C}$, rather phases such as $\mathrm{Na}_{3} \mathrm{MnO}_{4}$ and $\mathrm{Na}_{.70} \mathrm{MnO}_{2+\mathrm{y}}$ form at lower 
temperatures at $\mathrm{Na} / \mathrm{Mn}$ molar ratios of $1: 1$ (50). It has been shown that $\alpha$ and $\beta$ polymorphs coexist in the room temperature as the difference in formation energy between the two polymorphs lies between 5 and $18 \mathrm{meV}(51-53)$. At a synthesis temperature of $350^{\circ} \mathrm{C}$ $\left(\mathrm{K}_{B} \mathrm{~T}\right.$ of $\left.53.72 \mathrm{meV}\right)$, it is possible for the phases to coexist if low energy stacking faults are present (53). Stacking faults are indeed present as shown in the TEM diffraction of the structures (Fig. S12). Similar to electrodeposited $\mathrm{Na}_{x} \mathrm{CoO}_{2}$, concurrent charging of the electrodeposit during deposition results in formation of a partially charged $\alpha$ ' phase (indexed to $\mathrm{Cmcm}$ space group). $\mathrm{Cmcm} \mathrm{Na} .{ }_{67} \mathrm{MnO}_{2}$ is also known to be produced as a partially charged product during charging a $\mathrm{NaMnO}_{2}$ (48). The crystal structure of the major a' (O'3) phase is visualized in Fig. 4B and consists of a layered O'3 structure in a monoclinic lattice. Surface morphology (Fig. 4C) of the electrodeposits show elongated rod-like structures (Fig. 4D). Cross-sectional analysis (Fig. 4F) of $\sim 75 \%$ dense $20 \mu \mathrm{m}$ thick electrodeposited $\mathrm{Na}_{1.3} \mathrm{MnO}_{2+x}$ shows a uniform distribution of $\mathrm{Na}$ and $\mathrm{Mn}$ across the thickness (Fig. 4G). The electrodeposit undergoes a charge dependent phase transition during deposition (Fig. 4E). The charge reported is integrated from the l-t curve on a surface area of $2.25 \mathrm{~cm}^{2}$. For $14 \mathrm{mAh}$ of charge passed, there is a dominant presence of a $\mathrm{Mn}_{2} \mathrm{O}_{7}$ phase along with $\alpha^{\prime}$ (major, O'3) and $\beta$ (minor, $\mathrm{P} 2$ ) phases. It is difficult to find an exact match for the two peaks occurring at two theta values of $9.80^{\circ}$ and $10.98^{\circ}$ but $\mathrm{Mn}_{2} \mathrm{O}_{7}$ provides the most accurate match for the two primary peaks. With the passage of additional charge (23 mAh), the two peaks gradually diminish in intensity. Finally, after 37 mAh of charge the structure finally stabilize to only $\alpha^{\prime}$ (major), $\beta$ (minor) and partially charged $\alpha^{\prime}$ (minor) phases. Thermal annealing of the as-electrodeposited O'3 $\mathrm{Na}_{0.98} \mathrm{MnO}_{2}$ to $900^{\circ} \mathrm{C}$ and quenching the resultant phase arrests the high temperature orthorhombic P2 polymorph (with space group $\mathrm{cmcm}$ ) (Fig. S11).

\section{Electrodeposition from $\mathrm{Na}-\mathrm{Fe}-\mathrm{Cs}-\mathrm{O}$ system}

$\mathrm{NaFeO}_{2}$ is soluble in alkaline solution at room temperature and $\mathrm{Fe}^{2+}$ disproportionates in alkaline solutions above $60^{\circ} \mathrm{C}(54)$. Hence, molten $\mathrm{NaOH}$ chemically oxidizes $\mathrm{Fe}_{3} \mathrm{O}_{4}$ at high temperature $\left(350^{\circ} \mathrm{C}\right)$. This has been illustrated in Fig. $2 \mathrm{~K}$ where $\mathrm{Fe}^{2+} \mid \mathrm{Fe}^{3+}$ or higher valent redox systems are found to be absent. To improve the chemical stability of the $\mathrm{Fe}^{2+}$ (hydroxo) complex, the solvent is changed from $\mathrm{NaOH}$ to a $\mathrm{NaOH}-\mathrm{CsOH}$ mixture. $\mathrm{Cs}^{+}$ being a more polarizable cation than $\mathrm{Na}^{+}$, has a lower dissociation constant in a molten state, which in turn leads to a lower effective basicity in molten $\mathrm{NaOH}-\mathrm{CsOH}$ relative to 
pure $\mathrm{NaOH}$. As the basicity of the solvent (Fig. $2 \mathbf{J}$ ) is reduced, the $\mathrm{pH}_{2} \mathrm{O}$ is reduced, and oxidation power of the solvent is no longer sufficient to completely oxidize the $\mathrm{Fe}^{2+}$ complex. The stabilized $\mathrm{Fe}$ hydroxo complex with a $\mathrm{Fe}^{2+} \mid \mathrm{Fe}^{3+}$ redox can now be successfully electrochemically oxidized to $\mathrm{Na}_{x} \mathrm{FeO}_{2}$ and/or $\mathrm{CsFeO}_{2}$ based on the phase fraction of the hydroxides present. Phase formation at different mole fractions of $\mathrm{NaOH}$ i.e. $X_{\mathrm{NaOH}}=\mathrm{m}_{\mathrm{NaOH}} /\left(\mathrm{m}_{\mathrm{NaOH}}+\mathrm{m}_{\mathrm{CsOH}}\right)$ ( $m$ indicates the number of moles) is shown with the XRD of the corresponding electrodeposited phases in Fig. 5A and a synthesis plot is constructed in Fig. 5B with a possible mechanistic pathway in Fig. 5C. There is no deposit formation with pure $\mathrm{NaOH}$ as solvent. With the addition of $\mathrm{CsOH}$, at $\mathrm{X}_{\mathrm{CsOH}}=0.03\left(\mathrm{X}_{\mathrm{NaOH}}=\right.$ 0.97 ), $\mathrm{Na}_{x} \mathrm{FeO}_{2}$ phases are electrodeposited as two polymorphs, $\alpha$ (major) and $\beta$ (minor). With the increase of $\mathrm{X}_{\mathrm{CsOH}}$ up to $0.08, \mathrm{CsFeO}_{2}$ starts to appear in conjunction with the $\mathrm{Na}_{x} \mathrm{FeO}_{2}$ polymorphs. As the $\mathrm{CsOH}$ fraction increases further, even though it stabilizes the $\mathrm{Fe}^{2+}$ complex, once $\mathrm{X}_{\mathrm{CsOH}}$ exceeds $0.21\left(\mathrm{X}_{\mathrm{NaOH}}=0.79\right), \mathrm{CsFeO}_{2}$ becomes the major product. At $\mathrm{X}_{\mathrm{CsOH}}=0.65, \mathrm{CsFeO}_{2}$ forms as the sole product. There exists only a narrow zone of solvent basicity $\left(\mathrm{X}_{\mathrm{NaOH}}=0.92<x<0.97\right)$, where $\mathrm{Na}_{x} \mathrm{FeO}_{2}$ is the only product. The loading achieved in this narrow zone is $<0.1 \mathrm{mgcm}^{-2}$, limiting the practical utility. Replacing all of $\mathrm{CsOH}$ with $\mathrm{KOH}$ leads solely to the formation of $\mathrm{KFeO}_{2}$ (Table S6A) and changing the $\mathrm{NaOH}$ with molar equivalents of $\mathrm{NaCl}, \mathrm{Na}_{2} \mathrm{CO}_{3}$ or combinations thereof (Table S6B) does not improve the $\mathrm{Na}_{x} \mathrm{FeO}_{2}$ loading.

\section{Thermodynamic and kinetic factors of electrodepositing sodium transition metal oxides}

Multiple factors including the redox potential $\left(\mathrm{E}_{\mathrm{o}}\right.$, for $\left.\mathrm{M}^{2+} \mid \mathrm{M}^{3+}\right)$ and chemical stability of the transition metal complex in the +2-oxidation state, the chemical stability of the electrodeposited oxide and the oxidative electrochemical stability of the electrolyte strongly influence the viability of phase formation, growth rate and loading, which varies across different the transition metal chemistries. The optimized conditions for the depositions are summarized in Table 1. The criteria discussed in Fig. 2 are favorably present only for the $\mathrm{Na}-\mathrm{Co}-\mathrm{O}$ and $\mathrm{Na}-\mathrm{Mn}-\mathrm{O}$ systems for the solvent chemistries discussed in this work. Layered oxides have multiple temperature dependent metastable and thermodynamically stable polytypes that are critically linked to synthesis conditions. The electrodeposits of the sodium layered oxide family crystallize in thermodynamically stable low temperature rhombohedral $\mathrm{O} 3$ (or monoclinic O'3) polytype (as in Na-Co-O, Na-Mn- 
$\mathrm{O}$ and $\mathrm{Na}-\mathrm{Fe}-\mathrm{O})$, as the major phase along with slight presence of the high temperature orthorhombic beta polymorph (as in Jahn Teller active $\mathrm{Na}-\mathrm{Mn}-\mathrm{O}$ and $\mathrm{Na}-\mathrm{Fe}-\mathrm{O}$ ). The connecting thread across the chemistries grown by electrodeposition presented here, is the concurrent oxidation of the deposited material and formation of a partially desodiated phase in conjunction with a primary fully sodiated phase. The challenge of electrodepositing phase pure $\mathrm{NaMO}_{2}$ lies in the fact that fully sodiated $\mathrm{NaMO}_{2}$ are line compounds and any compositional variations during the electrosynthesis generates partially sodiated polytypes as minority phases. Attractively, the partially desodiated minority phases are all electrochemically active. If desired, they can be fully sodiated in a $\mathrm{Na}$ half-cell with an organic electrolyte. Growth rate and thickness during aqueous electrodeposition of oxide materials at room temperature suffer from intrinsic electronic conductivity challenges of the electrodeposited oxide, resulting in a poor growth rate $(\sim \mathrm{nm} / \mathrm{hr})$ and a self-limiting thickness $(<5 \mu \mathrm{m})$. However, layered sodium transition metal oxides are good electronic conductors in the partially and fully sodiated states $\left(\sim 350 \mathrm{Scm}^{-}\right.$ 1 for $\mathrm{Na}_{0.85} \mathrm{CoO}_{2}$ at $300 \mathrm{~K}(55), \sim 10^{-1} \mathrm{Scm}^{-1}$ for $\mathrm{Na}_{0.87} \mathrm{NiO}_{2}$ at $\sim 600 \mathrm{~K}$ (39), and $\sim 10^{-4} \mathrm{Scm}^{-1}$ for $\mathrm{NaFeO}_{2}$ at $350^{\circ} \mathrm{C}(56)$ ). The good electronic conductivity of the electrodeposited oxides is reflected in the current vs. time plots, (Fig. S2) which show high currents $\left(60 \mathrm{~mA} / \mathrm{cm}^{2}\right.$ for Na-Co-O, $95 \mathrm{~mA} / \mathrm{cm}^{2}$ for Na-Mn-O, $\sim 620 \mathrm{~mA} / \mathrm{cm}^{2}$ for $\mathrm{Na}-\mathrm{Ni}-\mathrm{O}$, and $\sim 30 \mathrm{~mA} / \mathrm{cm}^{2}$ for Na$\mathrm{Fe}-\mathrm{O})$ that remain roughly invariant as the oxide layer grows, indicating minimal resistances. The current profiles for $\mathrm{Na}-\mathrm{Co}-\mathrm{O}, \mathrm{Na}-\mathrm{Mn}-\mathrm{O}$ and $\mathrm{Na}-\mathrm{Fe}-\mathrm{O}$ reflect that the depositions are conducted in a kinetically controlled zone without diffusion limitations. O3 $\mathrm{Na}_{.98} \mathrm{CoO}_{2}$ and O'3 $\mathrm{Na}_{1.3} \mathrm{MnO}_{2}$ can be grown to $\sim 20-300 \mu \mathrm{m}$ thick at deposition rates of 14-22 $\mathrm{mg} / \mathrm{cm}^{2} / \mathrm{hr}$ and $\sim 5.5 \mathrm{mg} / \mathrm{cm}^{2} / \mathrm{hr}$ for $\mathrm{O} 3 \mathrm{Na}_{.98} \mathrm{CoO}_{2}$ and O'3 $\mathrm{Na}_{1.3} \mathrm{MnO}_{2+\mathrm{x}}$, respectively, while $\mathrm{Na}_{x} \mathrm{NiO}_{2}\left(\sim 0.5 \mathrm{mg} / \mathrm{cm}^{2} / \mathrm{hr}\right)$ and $\mathrm{Na}_{x} \mathrm{FeO}_{2}\left(\sim<0.1 \mathrm{mg} / \mathrm{cm}^{2} / \mathrm{hr}\right)$ are formed only to much lower loadings. Coulombic efficiency (CE) is an important parameter to quantify the amount of charge useful for the growth the electrodeposit. CE for SCO and SMO growth is $\sim 45 \%$ and $\sim 72 \%$ respectively, while the CE is extremely low $(\sim 1 \%)$ for the $\mathrm{Na}-\mathrm{Ni}-\mathrm{O}$ system because almost the entire charge is decomposing the electrolyte and only a small fraction is oxidizing the complex near the substrate. Minimally successful attempts to improve the loading by adopting strategies such as expanding the electrochemical stability window, use of more soluble precursors and controlled evolution of oxygen are detailed in SI2. 


\section{Electrochemical performance of as synthesized electrodeposited materials}

Electrochemical performance of the as deposited electrodeposits is analyzed in a half cell configuration with sodium metal reference and counter electrodes. CV at a sweep rate of $0.1 \mathrm{mVs}^{-1}$ serves to elucidate the phase transformations in the first and second cycle in the Na-M-O systems. All the electrodeposited STMOs (O3 $\mathrm{Na}_{0.98} \mathrm{CoO}_{2}$, Fig. 6Ai, O'3 $\mathrm{Na}_{1.3} \mathrm{MnO}_{2+x}$, Fig. 6Bi, O'3 $\mathrm{Na}_{x} \mathrm{NiO}_{2}$, Fig. 6C, and $\mathrm{O}^{\prime} 3 \mathrm{Na}_{x} \mathrm{FeO}_{2}$, Fig. 6D) are electrochemically active in the as-synthesized state and show distinct phase transitions corroborating the crystallinity of the as-deposited material. Peaks (and corresponding phase transformations) are observed at similar voltages (vs. $\mathrm{Na}$ ) for samples prepared by electrodeposition and solid-state synthesis (summarized in Table S2). The magnitude of currents for the cathodic and anodic reactions reflect the deposit loading. All the $\mathrm{O} 3$ (and O'3) systems undergo an irreversible phase transition to O'3 in the low voltage region (2.68 $\mathrm{V}$ in $\mathrm{SCO}, 2.81 \mathrm{~V}$ in $\mathrm{SMO}$ ) for the first cycle. Electrodeposited $\mathrm{O} 3 \mathrm{Na}_{0.98} \mathrm{CoO}_{2}$ shows a first cycle charge capacity of $132.7 \mathrm{mAh} / \mathrm{g}$ (charged to $3.8 \mathrm{~V}$ ) and a first cycle discharge capacity of $92.7 \mathrm{mAh} / \mathrm{g}$ (Fig. 5Aii). This is in close agreement with solid state synthesized O3 $\mathrm{Na}_{1} \mathrm{CoO}_{2}$, where charging $\mathrm{O} 3 \mathrm{Na}_{1.0} \mathrm{CoO}_{2}$ in the 2.0-3.8 $\mathrm{V}$ voltage range corresponds a desodiation of 0.59 moles of $\mathrm{Na}$ out of which 0.42 moles can be reintercalated back into the structure due to the irreversible formation of O'3 from $\mathrm{O} 3$ (44). The structure becomes electrochemically reversible after conversion of the O'3 to P'3 (Fig. S10C) resulting in a highly reversible capacity of $61 \mathrm{mAh} / \mathrm{g}$ from the $25^{\text {th }}$ to $100^{\text {th }}$ cycle at $\mathrm{C} / 10$. The reversible areal capacity achieved is $0.47 \mathrm{mAh} / \mathrm{cm}^{2}$ (Fig. 6Aii) with a capacity loss of $6 \%$ from the $50^{\text {th }}$ to $100^{\text {th }}$ cycle. The rate capability of electrodeposited SCO is good at $20 \mu \mathrm{A}(\mathrm{C} / 20)$, $40 \mu \mathrm{A}(\mathrm{C} / 10), 66 \mu \mathrm{A}(\mathrm{C} / 6), 0.15 \mathrm{~mA}(\mathrm{C} / 2)$, and $2.0 \mathrm{~mA}(15 \mathrm{C})$ with areal discharge capacities of $0.37,0.33,0.29,0.25$ and $0.11 \mathrm{mAh} / \mathrm{cm}^{2}$ (sample area of $1.13 \mathrm{~cm}^{2}$ and loading of $3.94 \mathrm{mg} / \mathrm{cm}^{2}$ (Fig. S6A)). The diffusion coefficient of $\mathrm{Na}^{+}$ions $\left(1.03^{*} 10^{-12} \mathrm{~cm}^{2} / \mathrm{s}\right.$ in electrodeposited $\mathrm{O} 3 \mathrm{Na}_{0.98} \mathrm{CoO}_{2}$ ) is not adversely affected by the lower synthesis temperature (Fig. S6Bi-ii). Electrodeposited O'3 $\mathrm{Na}_{1.3} \mathrm{MnO}_{2+x}$ shows a first cycle charge capacity of $252.2 \mathrm{mAh} / \mathrm{g}$ and a first cycle discharge capacity of $188.8 \mathrm{mAh} / \mathrm{g}$ (Fig. 6Bii). 0.85 moles of $\mathrm{Na}$ can be deintercalated out of the structure of which 0.63 moles can be reintercalated into the structure in the first discharge cycle. Electrodeposited sodium manganese oxide exhibits discharge capacities of $152.9,127.4$, and $115.5 \mathrm{mAh} / \mathrm{g}$ for the $10^{\text {th }}, 50^{\text {th }}$ and $100^{\text {th }}$ cycles, respectively, and the $50^{\text {th }}$ to $100^{\text {th }}$ cycle fade is $9 \%$. The 
electrodeposited materials deliver reversible areal capacities of the order of $\sim 0.2-0.5$ $\mathrm{mAh} / \mathrm{cm}^{2}$ (Fig. 6 Aiii, Biii), higher than capacities reported for binder-free sodium cathodes such as grown by vacuum deposition techniques at similar discharge current densities (Table S5, Fig. S8A.).

\section{Discussion}

Hydroxo complexes form the building blocks of the electrodeposited layered oxide structure, which on application of an oxidizing potential undergo polycondensation and precipitation. The coordination environment (octahedral/tetrahedral) of the complex is translated from solution to the solid phase and retained in the final product as sodium ion intercalated edge sharing polyhedral structures. During the electrocrystallization process, the kinetic pathways are presumed to be of low energy barrier and the temperature is sufficiently high to aid surface and bulk mobility of adatoms (or adions) to create crystalline deposits. The skewed $\mathrm{Na}^{+}: \mathrm{M}^{2+}$ ratio of $300: 1$ expands the thermodynamic domain for $\mathrm{NaMO}_{2}$ stabilization yielding layered oxides across all transition metal chemistries with none of the higher valent oxides (as in $\mathrm{Co}_{3} \mathrm{O}_{4}, \mathrm{Mn}_{3} \mathrm{O}_{4}, \mathrm{Fe}_{3} \mathrm{O}_{4}$ ) being present. This molar ratio however does not lead to sodium excess structures in the layered oxides except in $\mathrm{Na}-\mathrm{Mn}-\mathrm{O}$ system, where layered $\mathrm{Na}_{1.3} \mathrm{MnO}_{2+x}$ is electrodeposited. Moreover, since we use molten $\mathrm{NaOH}$ as the solvent, $\mathrm{NaOH}$ provides a sodium ion reservoir and actively prevents loss of sodium during synthesis, thus the $\mathrm{Na}$ stoichiometry is maintained at or near the fully sodiated stage. Across the materials, Na-Co-O, (Fig. 2C, Fig. S6), Na-Ni-O (Fig. S14), and Na-Fe-O (Fig. S17), the basic building blocks are hexagonal platelets, whereas rod-like structures are observed for the Na-Mn-O system (Fig. 4C).

Na-ion cathode materials synthesized by conventional routes have areal loadings of 1-5 $\mathrm{mg} / \mathrm{cm}^{2}$ and areal capacities in the range of 0.1-0.6 $\mathrm{mAh} / \mathrm{cm}^{2}$. We compare our dense electrodeposited cathodes with state-of-the-art solid-state synthesized $\mathrm{Na}$ cathodes (layered oxides and polyanion compounds), directly grown sodium cathodes by sputtering and PLD, and commercially used cathodes for $\mathrm{Na}$ ion batteries in Table S5 and Fig. S8A. Electrodeposited oxides of the $\mathrm{Na}-\mathrm{Co}-\mathrm{O}$ and $\mathrm{Na}-\mathrm{Mn}-\mathrm{O}$ system can match the electrochemical performance of bulk solid-state synthesized cathodes at even greater loadings of 2-10 mg/cm ${ }^{2}$ and reversible capacities in the range $0.2-0.5 \mathrm{mAh} / \mathrm{cm}^{2}$ and can be grown as high as $\sim 2.5 \mathrm{mAh} / \mathrm{cm}^{2}$ (Fig. S7C). Electrodeposited $\mathrm{O} 3 \mathrm{Na}_{.98} \mathrm{CoO}_{2}$ (Fig. S7A), 
O'3 $\mathrm{Na}_{1.3} \mathrm{MnO}_{2+x}$ (Fig. S13A), and O'3 $\mathrm{Na}_{x} \mathrm{NiO}_{2}$ (Fig. S15A) exhibit similar gravimetric capacities and intercalation/deintercalation profiles in the as-deposited state, at the same $\mathrm{C}$ rates as compared to the solid state thermochemically synthesized equivalents. The binder and additive free nature of the $>75 \%$ dense electrodes also improve the equivalent gravimetric and volumetric energy density by $\sim 20 \%$ and $\sim 40 \%$, respectively due to the absence of low-density polymer binder and carbon-based additives. Even though our cathodes are free of any additives, these exhibit minimal iR during charging, which is corroborated by minimal overpotential during the ordered phase transitions at a constant composition, as shown in Fig. S7A. The directly grown binder and additive free electrodeposits serve as model cathode systems for all solid-state $\mathrm{Na}$ ion batteries. Design

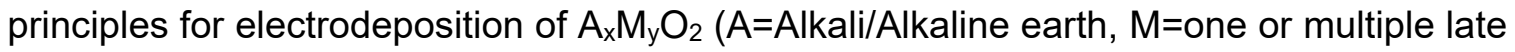
transition metal) can be formulated based on the observations reported here. The concept is compatible with multiple cathode chemistries such as $\mathrm{NaMO}_{2}$ (e.g. $\mathrm{M}=\mathrm{Cr}, \mathrm{V}, \mathrm{Ru}$ ), which crystallize in an alpha $\mathrm{NaFeO}_{2}$ type layered $\mathrm{O} 3$ type structure. Changing the alkali ion from $\mathrm{Na}$ to $\mathrm{K}$ or Li would lead to layered oxide cathodes of electrochemical importance such as $\mathrm{K}_{\mathrm{x}} \mathrm{CoO}_{2}$ (57) from a $\mathrm{KOH}$ based molten eutectic. The as-deposited $\mathrm{O} 3$ type cathodes can be thermally converted to the corresponding high temperature metastable P2 polytypes by thermal activation as previously observed in (58). In this study, we focus our attention on the electrochemical properties of the low temperature thermodynamically stable $\mathrm{O} 3$ (or O'3) type of $\mathrm{NaMO}_{2}$.

As we show here, it is possible to electrodeposit multiple important sodium transition metal oxides for electrochemical energy storage applications. To make further strides in this endeavor, expansion of the oxidative voltage stability window of the electrolyte would be crucial. This would accommodate redox couples with an $\mathrm{E}^{\circ}$ beyond the oxidative decomposition of the electrolyte (such as $\mathrm{Ni}^{2+} \mid \mathrm{Ni}^{3+}$ demonstrated here in this work). This would enable dense, adherent electrodeposits at a good faradaic efficiency for the electrodeposition process. Moreover, tuning of the dielectric constant and basicity $\left(\left[\mathrm{O}^{2-}\right]\right)$ of the solvent would dictate controllable selective precipitation/dissolution of desired/unwanted phases. Some proof-of-concept approaches to address these challenges are demonstrated for $\mathrm{Na}_{x} \mathrm{NiO}_{2}$ (SI2) and $\mathrm{Na}_{x} \mathrm{FeO}_{2}$ (Table S6A and Table S6B) electrosynthesis. 


\section{Conclusion}

In conclusion, we have demonstrated an intermediate temperature $\left(350^{\circ} \mathrm{C}\right)$ molten hydroxide mediated electrodeposition-based fabrication technique which enables electrosynthesis of layered STMOs at the lowest reported synthesis temperature and reaction time, in the form of thick polycrystalline films. These films successfully cycle, in a binder and additive free configuration, as intercalation cathode materials for SIB with near theoretical gravimetric capacity. Perhaps surprisingly, even when thick, the films exhibit adequate $\mathrm{Na}$-ion and electrical conductivity at reasonable charge and discharge rates. Atmosphere sensitive oxides including cathodes for $\mathrm{Na}$ ion batteries, previously considered incompatible with electrochemical growth, can now be accessed electrochemically by the general paradigm demonstrated here.

Based on the solubility of alkaline/alkaline earth group and late transition group/group 13/low group 14-15 ( $\mathrm{Sn}, \mathrm{Sb}, \mathrm{Pb}, \mathrm{Bi}$ ) oxides in molten salt hydroxides, our method, in principle, can be extended to fabricate oxide films with extended, such as layered and spinel, structures. The processing method can be applied to functional cobaltates, cuprates, and nickelates of interest for high temperature superconductivity applications. We hypothesize that there exists an unexplored experimental space for electrochemically crystallizing high valent inorganic structures with extended frameworks from their respective hydro solvents $(-\mathrm{OH},-\mathrm{SH})$ in the form of crystalline solid films via electrochemically initiated, thermally assisted polycondensation reactions.

\section{Materials and Methods}

$160 \mathrm{~g}(4 \mathrm{~mol})$ of $\mathrm{NaOH}$ (reagent grade, $\geq 98 \%$, anhydrous pellets) was dried in an Inconel crucible (250 mL capacity, Sigma) at $150{ }^{\circ} \mathrm{C}$ in a vacuum oven for one day and subsequently heated to $350^{\circ} \mathrm{C}$ on a hotplate in a nitrogen or Ar-filled glovebox atmosphere (oxygen and water level $<0.1 \mathrm{ppm}$ ), until the $\mathrm{NaOH}\left(\mathrm{T}_{\mathrm{m}}=318^{\circ} \mathrm{C}\right)$ solution was clear and dry. Molten $\mathrm{NaOH}$ is thermally stable at $350^{\circ} \mathrm{C}$ and there is minimal loss of solvent due to evaporation. There is no detectable reaction of the crucible with the molten hydroxide and nickel metal is known to be chemically stable up to $600{ }^{\circ} \mathrm{C}$ under $\operatorname{Ar}$ or $\mathrm{N}_{2}(59,60)$. The crucibles are enclosed in ceramic thermal insulation pads to prevent loss of heat. The transition metal precursor $\left(\mathrm{CO}_{3} \mathrm{O}_{4}, \mathrm{Mn}_{3} \mathrm{O}_{4}, \mathrm{Ni}(\mathrm{OH})_{2}, \mathrm{Fe}_{3} \mathrm{O}_{4}\right)$ was added slowly to the molten electrolyte to the desired $\mathrm{Na}^{+}: \mathrm{M}^{2+}$ molar ratio while stirring with a nickel spatula. The bath 
turns deep blue, light brown, dark green, reddish brown on addition of $\mathrm{Co}, \mathrm{Mn}, \mathrm{Ni}$, and $\mathrm{Fe}$ precursors, respectively, due to the formation of the corresponding hydroxo complex $\mathrm{Co}(\mathrm{OH})_{4}{ }^{2-}, \mathrm{Ni}(\mathrm{OH})_{3}{ }^{1-}, \mathrm{Mn}(\mathrm{OH})_{4}{ }^{2-}, \mathrm{Fe}(\mathrm{OH})_{4}{ }^{2-}$. Nickel foil is chosen as the working $\left(2.25 \mathrm{~cm}^{2}\right)$ and counter electrode $\left(3.0 \mathrm{~cm}^{2}\right)$ for the CV experiments (Fig. 2, $2^{\text {nd }}$ column) conducted at a scan rate of $10 \mathrm{mV} / \mathrm{s}$. A potentiostatic pulse waveform with a peak potential was used for deposition: $0.60 \mathrm{~V}$ (vs Mo), $1.20 \mathrm{~V}$ (vs. W), $0.97 \mathrm{~V}$ (vs. W), and $0.85 \mathrm{~V}$ (vs. W) for electrodeposition of $\mathrm{O} 3 \mathrm{Na}_{x} \mathrm{CoO}_{2}, \mathrm{O}^{\prime} 3 \mathrm{Na}_{x} \mathrm{MnO}_{2}, \mathrm{O}^{\prime} 3 \mathrm{Na}_{x} \mathrm{NiO}_{2}$ and $\mathrm{O} 3 \mathrm{Na}_{x} \mathrm{FeO}_{2}$, respectively. Duty cycle for all the depositions was $0.25 \mathrm{st}$-on and $8.0 \mathrm{st}$-off to reduce local $\mathrm{pH}$ gradients and diffusion limitations. Mo and $\mathrm{W}$ wire were used as pseudo-reference electrode for $\mathrm{Na}-\mathrm{Co}-\mathrm{O}-$ based depositions and $\mathrm{Na}-\mathrm{Mn}-\mathrm{O}, \mathrm{Na}-\mathrm{Ni}-\mathrm{O}$ and $\mathrm{Na}-\mathrm{Fe}-\mathrm{O}-$ based depositions, respectively. We note, metals with a melting point $>400^{\circ} \mathrm{C}$ and low chemical reactivity with $\mathrm{NaOH}$ are suitable substrates (working electrodes). Please note that our electrodeposited cathodes can be grown on battery grade aluminum, stainless steel and battery grade nickel foil and are compatible with other $\mathrm{Na}$ ion battery electrolytes such as 0.6 $\mathrm{M} \mathrm{NaPF}_{6}$ in EC:PC (1:1 by vol). Most typically used was a nickel foil which was at least $90 \%$ submerged into the electrodeposition solution and connected to the potentiostat using a copper alligator clip. For the thermal conversion to the high temperature beta (P2) phase, the as electrodeposited $\mathrm{O} 3 \mathrm{NaCoO}_{2}$ and $\mathrm{O}^{\prime} 3 \mathrm{NaMnO}_{2}$ is annealed to $900^{\circ} \mathrm{C}$ at a ramp rate of $5^{\circ} \mathrm{C} / \mathrm{min}$ and held at $900^{\circ} \mathrm{C}$ for $6 \mathrm{hr}$ and quenched.

Electrodeposited samples were washed with dry absolute ethanol $(<0.005 \mathrm{wt} \%$ water, Sigma) to remove excess solid hydroxide on the surface of the deposit. Note, prior to use as a washing solvent, the as-received alcohol is dried with $3 \AA$ molecular sieves $(20 \% \mathrm{~m} / \mathrm{v})$ for a week. After washing, samples were dried at $80{ }^{\circ} \mathrm{C}$ for one day. Electrolyte used in cells was $1.0 \mathrm{M} \mathrm{NaClO}_{4}$ in PC: FEC (98:2 by vol\%). Two glass fiber filters (Whatman glass microfiber filters, Grade GF/F) were used as the separator. Swagelok cells were tested in a half cell configuration with a sodium metal anode. Sodium cubes were purchased from sigma, dipped in hexane to remove residual oil, rolled into $20 \mu \mathrm{m}$ thin $\mathrm{Na}$ foils and punched as $12 \mathrm{~mm}$ diameter disks.

X-Ray diffraction measurements were conducted in a Bruker D8 Advance with a Cu source in reflection mode for the electrodeposited film samples sealed with a mylar/Kapton film. For structural analysis, the deposits were scraped off, finely ground and sealed inside 
a capillary tube and measured in the transmission mode using a Mo source. Rietveld refinements were carried out in Topas5.

Cross-sectional samples were prepared using a Gatan PECS II ion miller in single modulation configuration with a sample rotation speed of at $0.5 \mathrm{rpm}$ at a gun voltage $8 \mathrm{kV}$ for 1 hour with a $0^{\circ}$ gun tilt. Scanning electron micrographs were taken using a Hitachi S4700 SEM. Density of the electrodeposited materials was calculated based on the theoretical density of the respective deposited material, the cross-sectional area, the deposit thickness, and the deposit mass.

Cross sectional SEM for analysis of cycled samples were performed with a Thermo Scientific Scios 2 Dual Beam focused ion beam (FIB). Before sectioning, the top surface was protected with a $2 \mu \mathrm{m}$ layer platinum via ion beam induced deposition (IBID). Then ion milling was performed with a series of beam current from high to low with $100 \mathrm{pA}$ as the last step ensuring minimal beam damage related artifacts.

The TEM images, selected area electron diffraction (SAED) patterns and scanning electron nanobeam diffraction (SEND) data were acquired with a JEOL 2100 Cryo TEM equipped with a $\mathrm{LaB}_{6}$ emitter operating at $200 \mathrm{kV}$. SAED patterns were acquired using a camera length of $25 \mathrm{~cm}$. In SEND $(61,62)$ a nanometer-sized electron beam is scanned across a sample and diffraction patterns corresponding to each spot of the scan are collected. The diffraction patterns and relevant information (e.g., diffraction intensity, intensity ratio between different phases) are collected using a slow scan CCD camera and mapped according to their probe positions. The electron probe used for SEND acquisition is a semi-convergent electron beam of $5 \mathrm{~nm}$ (full-width half maximum). The scanning diffraction patterns are acquired over an area of $500 \mathrm{~nm} \times 500 \mathrm{~nm}$ in $25 \times 25$ pixels, corresponding to a step size of $20 \mathrm{~nm}$. In our SEND experiment, 4 times binning $(512 \times$ 512 pixels) is used. The typical exposure time for each diffraction pattern is $0.1 \mathrm{~s}$. A total of 625 diffraction patterns are recorded within 15 minutes without a beam stop. The obtained diffraction images are further processed to extract structural information.

\section{Acknowledgments}

This work was supported by the Office of Naval Research (ONR) through the Navy and Marine Corps Department of Defense University Research-to-Adoption (DURA) 
Initiative (N00014-18-S-F004) (electrode growth and characterization), the US Army CERL W9132T-19-2-0008 (electrode testing) and the National Science Foundation Engineering Research Center for Power Optimization of Electro Thermal Systems (POETS) (with cooperative Agreement No. EEC-1449548 (cell assembly). Significant aspects of the characterization were performed using the shared user facilities of the University of Illinois Materials Research Laboratory.

\section{References}

1. A. Stein, S. W. Keller, T. E. Mallouk, Turning Down the Heat: Design and Mechanism in Solid-State Synthesis. Science (80-. ). 259, 1558-1564 (1993).

2. C. M. Hall, Process of reducing Aluminum from its fluoride salts by electrolysis (1889).

3. A. J. T. L. Gerald F.Fountain, Casa Grande; John P. Pringle, Electrowinning of copper (1973).

4. Kroll W, Method for manufacturing titanium and alloys thereof (1940).

5. D. R. Sadoway, New opportunities for metals extraction and waste treatment by electrochemical processing in molten salts. J. Mater. Res. 10, 487-492 (1995).

6. L. D. Ellis, A. F. Badel, M. L. Chiang, R. J.-Y. Park, Y.-M. Chiang, Toward electrochemical synthesis of cement-An electrolyzer-based process for decarbonating $\mathrm{CaCO} 3$ while producing useful gas streams . Proc. Natl. Acad. Sci. , 201821673 (2019).

7. J. A. Switzer, Electrodeposited ceramic single crystals. Science (80-. ). 284, 293296 (1999).

8. N. Tian, Z.-Y. Zhou, N.-F. Yu, L.-Y. Wang, S.-G. Sun, Direct Electrodeposition of Tetrahexahedral Pd Nanocrystals with High-Index Facets and High Catalytic Activity for Ethanol Electrooxidation. J. Am. Chem. Soc. 132, 7580-7581 (2010).

9. H. Zhang, X. Yu, P. V Braun, Three-dimensional bicontinuous ultrafast-charge and -discharge bulk battery electrodes. Nat. Nanotechnol. 6, 277-281 (2011).

10. Z. J. Schiffer, K. Manthiram, Electrification and Decarbonization of the Chemical Industry. Joule 1, 10-14 (2017).

11. D. Kundu, E. Talaie, V. Duffort, L. F. Nazar, The emerging chemistry of sodium ion batteries for electrochemical energy storage. Angew. Chemie - Int. Ed. 54, 3432-3448 (2015).

12. K. Kubota, S. Kumakura, Y. Yoda, K. Kuroki, S. Komaba, Electrochemistry and 
Solid-State Chemistry of $\mathrm{NaMeO} 2$ (Me $=3 d$ Transition Metals). Adv. Energy Mater. 8, 1703415 (2018).

13. H. Wang, et al., Short $\mathrm{O}\{$ ltextendash\}O separation in layered oxide $\mathrm{Na} 0.67 \mathrm{CoO} 2$ enables an ultrafast oxygen evolution reaction. Proc. Natl. Acad. Sci. 116, 23473 23479 (2019).

14. E. R. Ylvisaker, K. Lee, W. E. Pickett, Superconducting Non-cuprate Transition Metal Oxide Superconductors. 125, 0-3 (2001).

15. T. Shibata, Y. Fukuzumi, W. Kobayashi, Y. Moritomo, Fast discharge process of layered cobalt oxides due to high $\mathrm{Na}+$ diffusion. Sci. Rep. 5, 8-11 (2015).

16. P. Kehne, et al., Electrochemical performance of all-solid-state sodium-ion model cells with crystalline $\mathrm{NaxCoO} 2$ thin-film cathodes. J. Electrochem. Soc. 166, A5328-A5332 (2019).

17. C. Guhl, et al., Interfaces in solid-state sodium-ion batteries: NaCoO2 thin films on solid electrolyte substrates. Electrochim. Acta 268, 226-233 (2018).

18. C. Guhl, et al., In-operando photoelectron spectroscopy for batteries: Set-up using pristine thin film cathode and first results on NaxCoO2. Rev. Sci. Instrum. 89 (2018).

19. L. Baggetto, et al., Sodium Manganese Oxide Thin Films as Cathodes for Na-Ion Batteries. \{ECS\} Trans. 58, 47-57 (2014).

20. S. Baskar, R. Angalakuthi, C. Murugesan, S. B. Krupanidhi, P. Barpanda, Exploration of iron-based mixed polyanion cathode material for thin-film sodiumion batteries. ECS Trans. 85, 227-234 (2018).

21. J. A. Switzer, The n-Silicon/Thallium(III) Oxide Heterojunction Photoelectrochemical Solar Cell. J. Electrochem. Soc. 133, 722 (1986).

22. J. A. Koza, Z. He, A. S. Miller, J. A. Switzer, Electrodeposition of Crystalline Co 3 $\mathrm{O}_{4}-\mathrm{A}$ Catalyst for the Oxygen Evolution Reaction. Chem. Mater. 24, 3567-3573 (2012).

23. T. A. Sorenson, S. A. Morton, G. D. Waddill, J. A. Switzer, Epitaxial Electrodeposition of $\mathrm{Fe}_{3} \mathrm{O}_{4}$ Thin Films on the Low-Index Planes of Gold. J. Am. Chem. Soc. 124, 7604-7609 (2002).

24. T. Sasaki, Y. Ogawa, Method Electrochemical Oxidation of LaMnO, Perovskite Using. J. Solid State Chem. 91, 61-70 (1991).

25. Y. Lee, et al., Preparation and Characterization of Sodium Tantalate Thin Films by Hydrothermal-Electrochemical Synthesis. Chem. Mater. 17, 2422-2426 (2005).

26. M. Alsabet, M. Grdeń, G. Jerkiewicz, Electrochemical Growth of Surface Oxides on Nickel. Part 3: Formation of $\beta-\mathrm{NiOOH}$ in Relation to the Polarization Potential, Polarization Time, and Temperature. Electrocatalysis 6, 60-71 (2015). 
27. D. Tench, Electrodeposition of Conducting Transition Metal Oxide/Hydroxide Films from Aqueous Solution. J. Electrochem. Soc. 130, 869 (2006).

28. G. H. A. Therese, P. V. Kamath, Electrochemical synthesis of metal oxides and hydroxides. Chem. Mater. 12, 1195-1204 (2000).

29. C. R. Baes; R. E. Messmer, "The first transition series" in The Hydrolysis of Cations, (John Wiley \& Sons Inc, 1976), pp. 219-246.

30. Bruce C Bunker \& William H Casey, "Fundamental oxide reactions in aqueous solutions" in The Aqueous Chemistry of Oxides, (Oxford University Press, 2013), pp. 87-117, 167-191.

31. M. Henry, J. P. Jolivet, J. Livage, "Aqueous chemistry of metal cations: Hydrolysis, condensation and complexation" in Chemistry, Spectroscopy and Applications of Sol-Gel Glasses, (Springer, Berlin, Heidelberg, 2006), pp. 153206.

32. P. F. Wang, Y. You, Y. X. Yin, Y. G. Guo, Layered Oxide Cathodes for SodiumIon Batteries: Phase Transition, Air Stability, and Performance. Adv. Energy Mater. 8, 1-23 (2018).

33. H. Zhang, et al., Electroplating lithium transition metal oxides. Sci. Adv. 3, 1-9 (2017).

34. B. L. Tremillon, "Acid-Base Effects in Molten Electrolytes" in Molten Salt Chemistry. NATO ASI Series (Series C: Mathematical and Physical Sciences), Vol 202, (Springer, Dordrecht, 1985), pp. 345-351.

35. H. Hayashi, S. Yoshizawa, Y. Ito, Electrochemical studies on molten sodium hydroxide. J. Electroanal. Chem. Interfacial Electrochem. 124, 229-235 (1981).

36. H. Hayashi, S. Yoshizawa, Y. Ito, Studies on oxygen reduction in molten $\mathrm{NaOH}$. Electrochim. Acta 28, 149-153 (1983).

37. R. Dorin, H. J. Gardner, L. J. Rogers, The sodium reference electrode in molten sodium hydroxide. J. Electroanal. Chem. Interfacial Electrochem. 77, 385-389 (1977).

38. J. Goret, B. Tremillon, Propriétés chimiques et électrochimiques en solution dans les hydroxydes alcalins fondus-IV. Comportement électrochimique de quelques métaux utilisés comme électrodes indicatrices. Electrochim. Acta 12, 1065-1083 (1967).

39. K. Momma, F. Izumi, \{lit VESTA3\} for three-dimensional visualization of crystal, volumetric and morphology data. J. Appl. Crystallogr. 44, 1272-1276 (2011).

40. Y. Lei, X. Li, L. Liu, G. Ceder, Synthesis and Stoichiometry of Di ff erent Layered Sodium Cobalt Oxides. Chem. Mater. 26, 5288-5296 (2014).

41. L. Viciu, et al., Crystal structure and elementary properties of Nax Co O2 ( $\mathrm{x}=0.32$, $0.51,0.6,0.75$, and 0.92 ) in the three-layer NaCo $\mathrm{O} 2$ family. Phys. Rev. B - 
Condens. Matter Mater. Phys. 73, 1-10 (2006).

42. Y. Takahashi, Y. Gotoh, J. Akimoto, Single-crystal growth, crystal and electronic structure of NaCoO2. J. Solid State Chem. 172, 22-26 (2003).

43. D. Kramer, G. Ceder, Tailoring the morphology of LiCoO2: A first principles study. Chem. Mater. 21, 3799-3809 (2009).

44. Y. Lei, X. Li, L. Liu, G. Ceder, Synthesis and stoichiometry of different layered sodium cobalt oxides. Chem. Mater. 26, 5288-5296 (2014).

45. Y. Lei, "Determination of the Synthesis Diagram of Sodium Cobalt Oxide and Electrochemical Study," Massachusetts Institute of Technology. (2014).

46. C. Delmas, J.-J. Braconnier, C. Fouassier, P. Hagenmuller, Electrochemical intercalation of sodium in NaxCoO2 bronzes. Solid State Ionics 3-4, 165-169 (1981).

47. L. W. Shacklette, Rechargeable Electrodes from Sodium Cobalt Bronzes. J. Electrochem. Soc. 135, 2669 (1988).

48. X. Ma, H. Chen, G. Ceder, Electrochemical properties of monoclinic NaMnO2. J. Electrochem. Soc. 158, 1307-1312 (2011).

49. A. Mendiboure, C. Delmas, P. Hagenmuller, Electrochemical intercalation and deintercalation of NaxMnO2 bronzes. J. Solid State Chem. 57, 323-331 (1985).

50. J.-P. Parant, R. Olazcuaga, M. Devalette, C. Fouassier, P. Hagenmuller, Sur quelques nouvelles phases de formule NaxMnO2 $(x \leqslant 1)$. J. Solid State Chem. 3 , 1-11 (1971).

51. R. J. Clément, D. S. Middlemiss, I. D. Seymour, A. J. Ilott, C. P. Grey, Insights into the nature and evolution upon electrochemical cycling of planar defects in the $\beta$ $\mathrm{NaMnO} 2 \mathrm{Na}$-ion battery cathode: An NMR and first-principles density functional theory approach. Chem. Mater. 28, 8228-8239 (2016).

52. O. I. Velikokhatnyi, C. C. Chang, P. N. Kumta, Phase Stability and Electronic Structure of NaMnO2. J. Electrochem. Soc. 150, 2-7 (2003).

53. A. M. Abakumov, A. A. Tsirlin, I. Bakaimi, G. Van Tendeloo, A. Lappas, Multiple twinning as a structure directing mechanism in layered rock-salt-type oxides: $\mathrm{NaMnO} 2$ polymorphism, redox potentials, and magnetism. Chem. Mater. 26, 3306-3315 (2014).

54. X. Zou, et al., Facile electrodeposition of iron films from $\mathrm{NaFeO} 2$ and $\mathrm{Fe} 2 \mathrm{O} 3$ in alkaline solutions. J. Electrochem. Soc. 162, D49-D55 (2015).

55. P. Liu, et al., High temperature electrical conductivity and thermoelectric power of NaxCoO2. Solid State Ionics 179, 2308-2312 (2008).

56. M. C. Blesa, et al., a-NaFeO2: ionic conductivity and sodium extraction. Solid State Ionics 126, 81-87 (1999). 
57. Y. Hironaka, K. Kubota, S. Komaba, P2- and P3-KxCoO2 as an electrochemical potassium intercalation host. Chem. Commun. 53, 3693-3696 (2017).

58. M. Bianchini, et al., The interplay between thermodynamics and kinetics in the solid-state synthesis of layered oxides. Nat. Mater. (2020) https:/doi.org/10.1038/s41563-020-0688-6.

59. D. D. Williams, J. A. Grand, R. R. Miller, The Reactions of Molten Sodium Hydroxide with Various Metals1. J. Am. Chem. Soc. 78, 5150-5155 (1956).

60. B. L. Spatocco, "Investigation of Molten Salt Electrolytes for Low-Temperature Liquid Metal Batteries," Massachusetts Institute of Technology. (2015).

61. J. M. Zuo, J. C. H. Spence, "Instrumentation and Experimental Techniques BT Advanced Transmission Electron Microscopy: Imaging and Diffraction in Nanoscience" in J. M. Zuo, J. C. H. Spence, Eds. (Springer New York, 2017), pp. 231-295.

62. J.-M. Zuo, J. Tao, "Scanning Electron Nanodiffraction and Diffraction Imaging BT - Scanning Transmission Electron Microscopy: Imaging and Analysis" in S. J. Pennycook, P. D. Nellist, Eds. (Springer New York, 2011), pp. 393-427. 


\section{Figures and Tables}

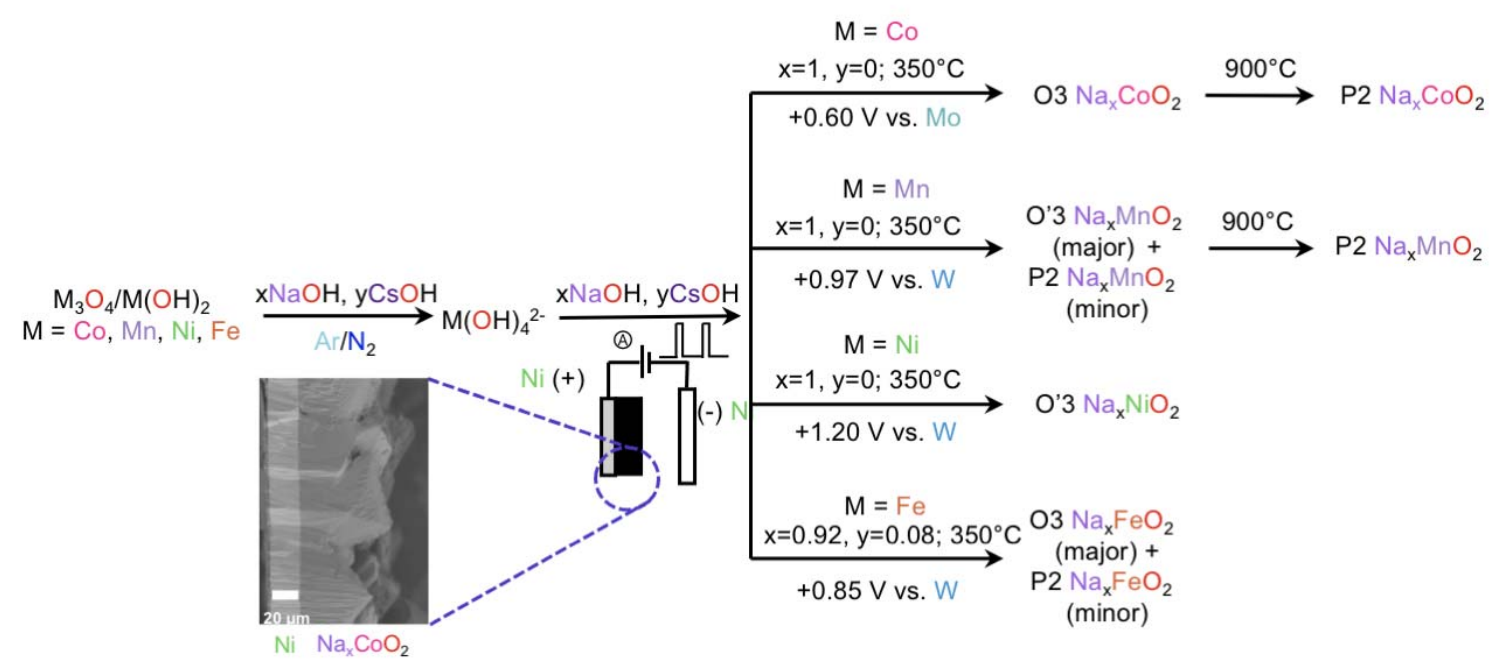

Figure 1. Reaction conditions for molten hydroxide-mediated anodic electrodeposition of layered STMOs of general form Na-M-O (M= Co, Mn, Ni, Fe) at $350^{\circ} \mathrm{C}$. Scanning electron microscope (SEM) image below the reaction shows $\sim 60 \mu \mathrm{m}$ thick $\mathrm{Na}_{\mathrm{x}} \mathrm{CoO}_{2}$ on a nickel foil (nickel foil is the brighter band on left side of image). 

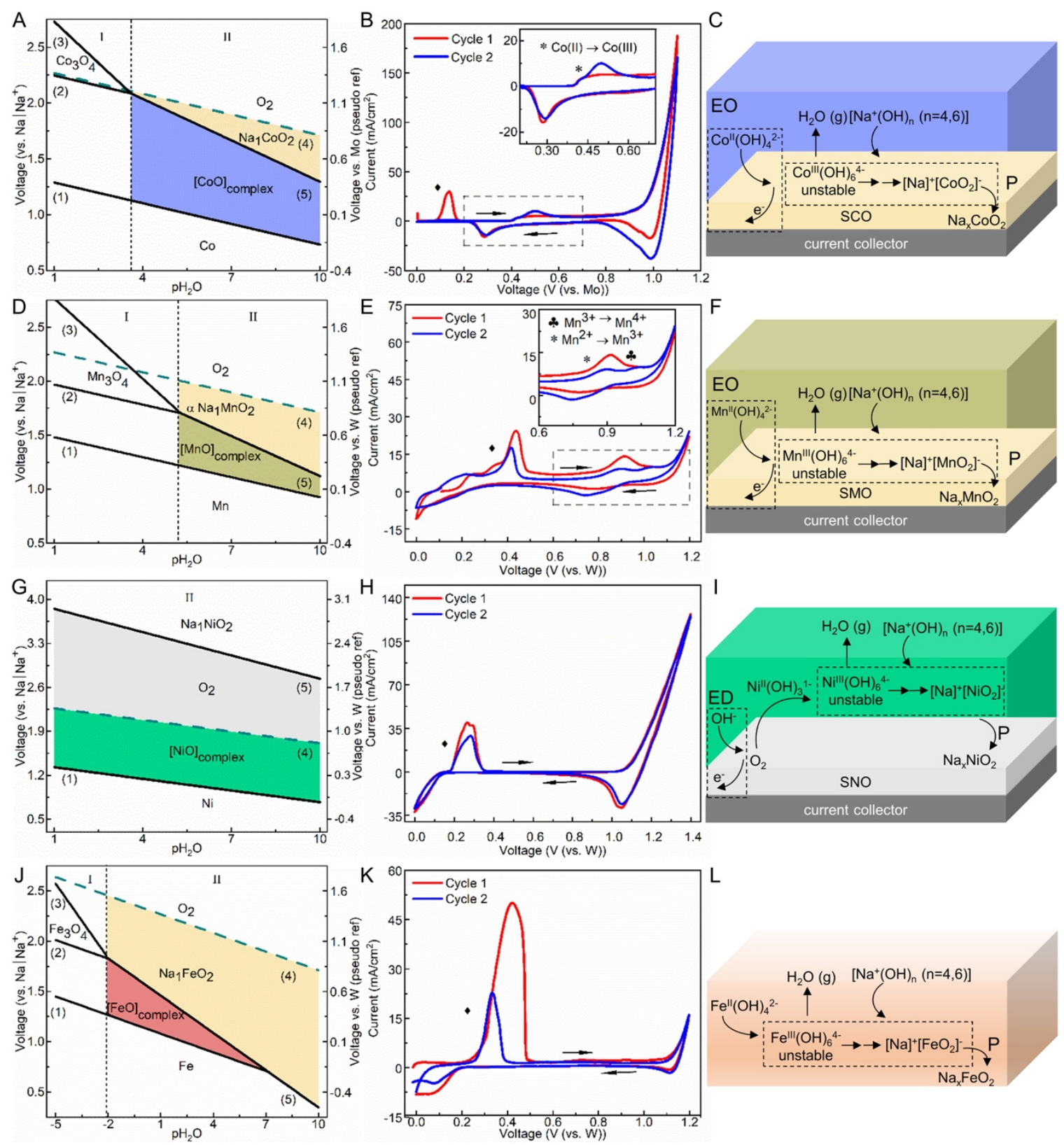

Figure 2. First column shows the Pourbaix diagrams of A. Na-Co-O, D. Na-Mn-O, G. Na$\mathrm{Ni}-\mathrm{O}$ and $\mathrm{J}$. Na-Fe-O systems in molten $\mathrm{NaOH}$ at $350{ }^{\circ} \mathrm{C}$. Lines $1,2,3,4$, and 5 indicate interphase stability between $\mathrm{M}|\mathrm{MO}, \mathrm{MO}| \mathrm{M}_{3} \mathrm{O}_{4}, \mathrm{M}_{3} \mathrm{O}_{4}\left|\mathrm{NaMO}_{2}, \mathrm{MO}\right| \mathrm{NaMO}_{2}$ and $\mathrm{OH}^{-} \rightarrow \mathrm{O}_{2}$ respectively. The color of the (MO) complex domain is representative of the color of the complex in the electrolyte. There exist two domains labelled I and II where oxidation of the +2 complex results in the higher valent mixed oxide $\left(\mathrm{M}_{3} \mathrm{O}_{4}\right)$ and the $\mathrm{Na}$ intercalated $\mathrm{MO}_{2}{ }^{-}$ (light yellow) respectively. Second column shows cyclic voltammograms of the B. Na-Co- 
O, E. Na-Mn-O, H. Na-Ni-O and K. Na-Fe-O systems in molten $\mathrm{NaOH}$ at $350^{\circ} \mathrm{C}$ for the first (red) and second (blue) cycles at a scan rate of $10 \mathrm{mVs}^{-1}$. Third column presents schematics of the possible mechanistic pathway for electrodeposition of the $\mathbf{C}$. Na-Co-O, F. Na-Mn-O, I. Na-Ni-O and L. Na-Fe-O systems. 

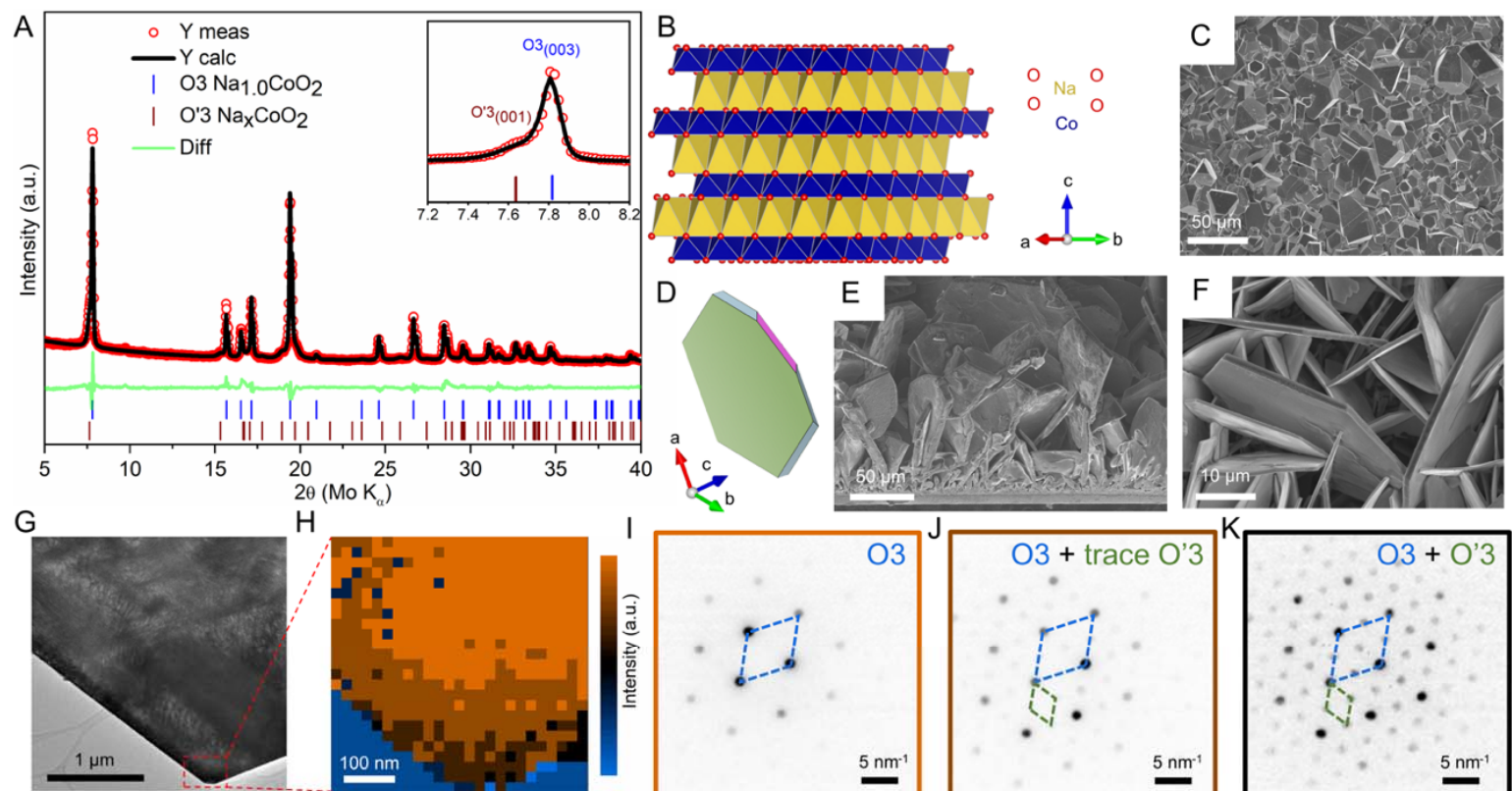

$\mathrm{H}$

L
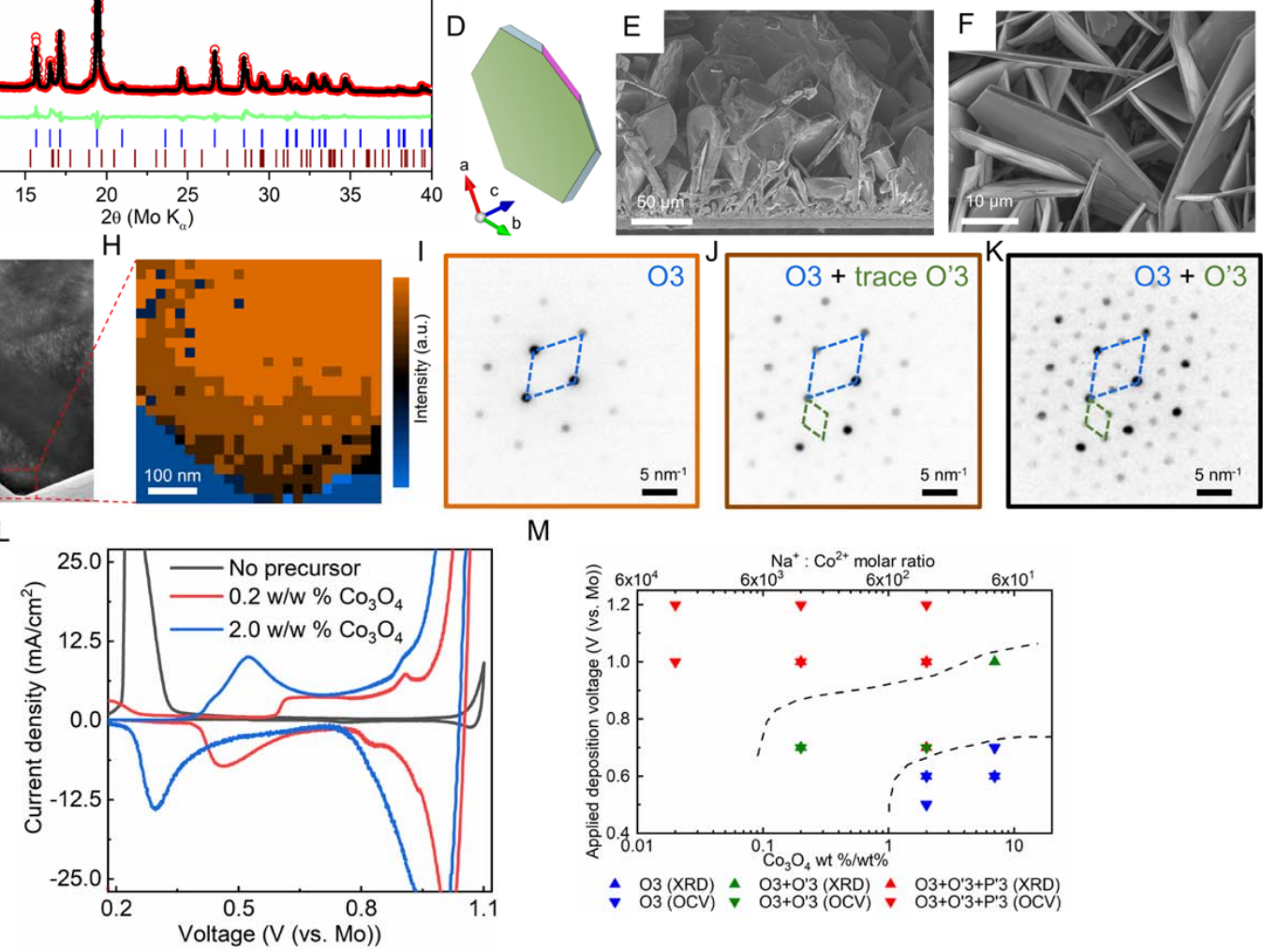

M

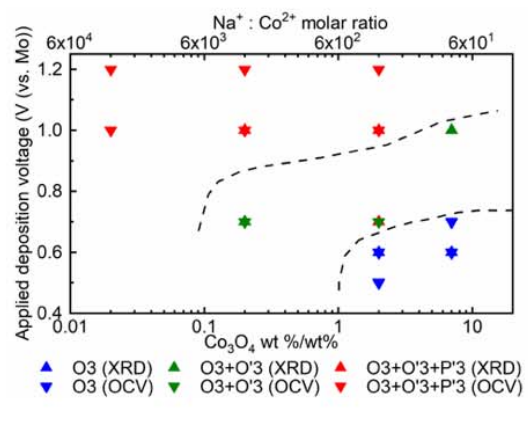

Figure 3. Electrodeposition from $\mathrm{Na}-\mathrm{Co}-\mathrm{O}$ system. A. XRD of electrodeposited $\mathrm{O} 3$ layered $\mathrm{NaCoO}_{2}$. B. Visualization of the electrodeposited $\mathrm{O} 3$ crystal structure at $0.6 \mathrm{~V}$. $\mathrm{Na}$, $\mathrm{Co}$, and $\mathrm{O}$ atoms are color-coded in yellow, blue, and red, respectively. C. Top view SEM image of electrodeposited dense $\mathrm{NaCoO}_{2}$. D. Visualization of the surface terminating planes in the platelets electrodeposited sodium cobalt oxide. E. Cross-sectional and F. top-view SEM images of electrodeposited $\mathrm{NaCoO}_{2}$. G. TEM image of a section of an electrodeposited platelet. H. A spatial phase map by SEND from the area (marked by red dotted border in G.) shows that the central major part of the platelet is $\mathrm{O} 3$ whereas a thin layer of O'3 is formed at the edge of the platelets $(\sim 60-120 \mathrm{~nm})$. Diffraction patterns are acquired from I. center (light brown square), J. middle (deep brown square), and K. edge of the platelet (black square). L. Cyclic voltammetry curves in no precursor, $0.2 \mathrm{w} / \mathrm{w} \%$ 
$\mathrm{Co}_{3} \mathrm{O}_{4}$, and $2.0 \mathrm{w} / \mathrm{w} \% \mathrm{Co}_{3} \mathrm{O}_{4}$ in molten $\mathrm{NaOH}$. M. Phase map for the electrodeposited samples of the Na-Co-O system as a function of the peak applied voltage and $\mathrm{Co}_{3} \mathrm{O}_{4}$ concentration. Dotted lines are a guide to the eye. 

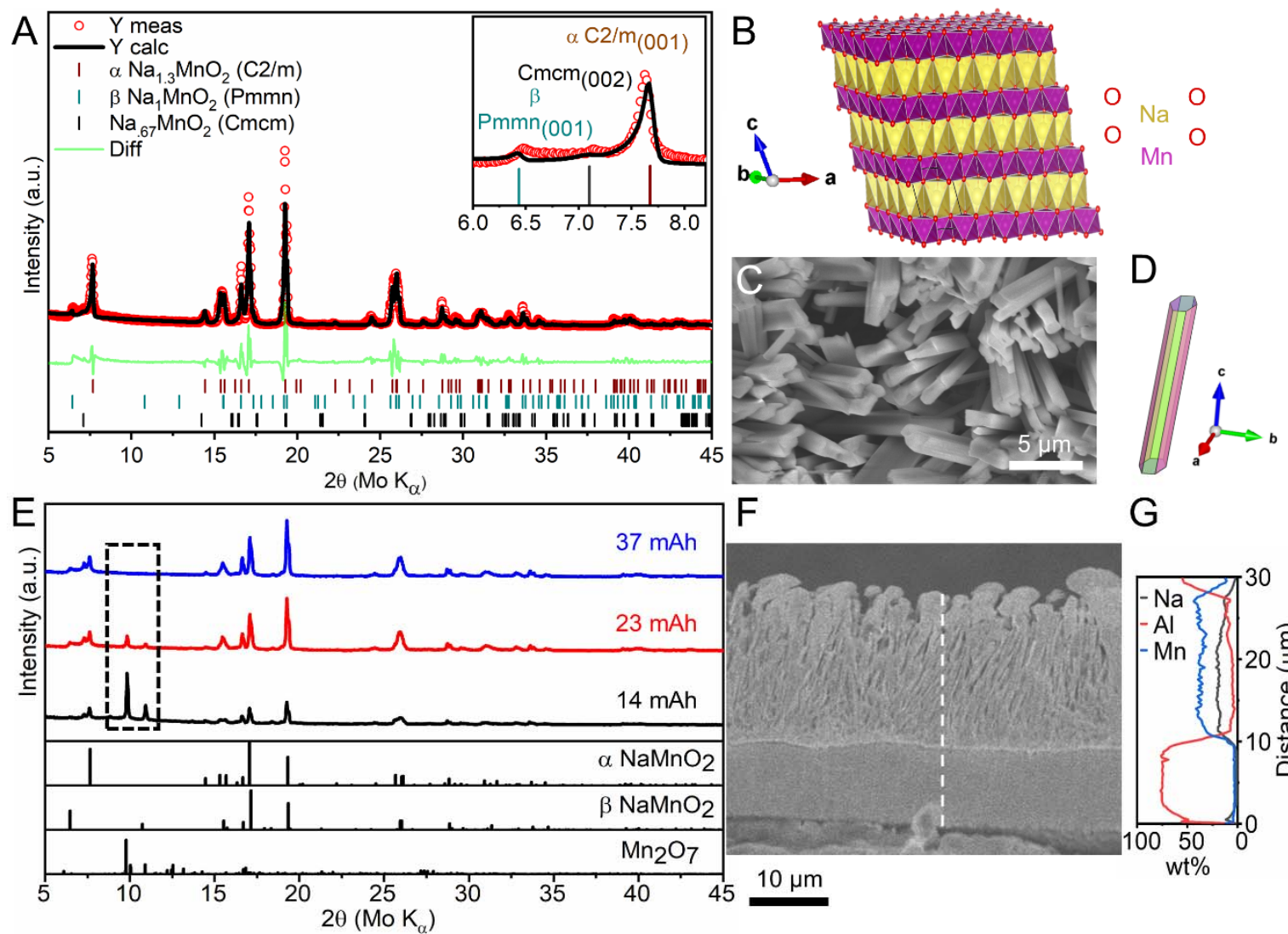

$\mathrm{F}$

G

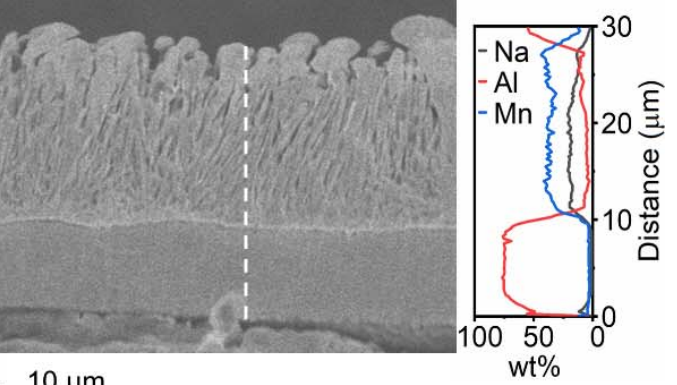

$10 \mu \mathrm{m}$

Figure 4. Electrodeposition from Na-Mn-O system. A. XRD of as-synthesized electrodeposit at $0.97 \mathrm{~V}$ (vs. W) from $3.04 \mathrm{~g}$ of $\mathrm{Mn}_{3} \mathrm{O}_{4}$ in $160 \mathrm{~g} \mathrm{NaOH}\left(\mathrm{Na}^{+}\right.$or $\mathrm{OH}^{-}: \mathrm{Mn}^{2+}=$ $300: 1)$ at $350^{\circ} \mathrm{C}$ showing O'3 ( $\left.\alpha^{\prime}\right) \mathrm{Na}_{1.3} \mathrm{MnO}_{2+x}(94.56 \%), \beta \mathrm{NaMnO}_{2}(1.99 \%)$ and $\mathrm{Cmcm}$ $\mathrm{Na} .67 \mathrm{MnO}_{2}(3.45 \%)$. B. Visualization of the unit cell of the electrodeposited O'3 a phase. $\mathrm{Na}$ (yellow), Mn (magenta), and O (red) atoms are color-coded. C. Top-view SEM image of the electrodeposit showing elongated rod-like structures. D. Visualization of the surface terminating planes in the rod-like structures. E. XRD illustrating charge-dependent phase transition in electrodeposits from Na-Mn-O system. F. Cross-sectional SEM image and G. line EDS of $\sim 75 \%$ dense electrodeposited sodium manganese oxide along dotted line in F. 

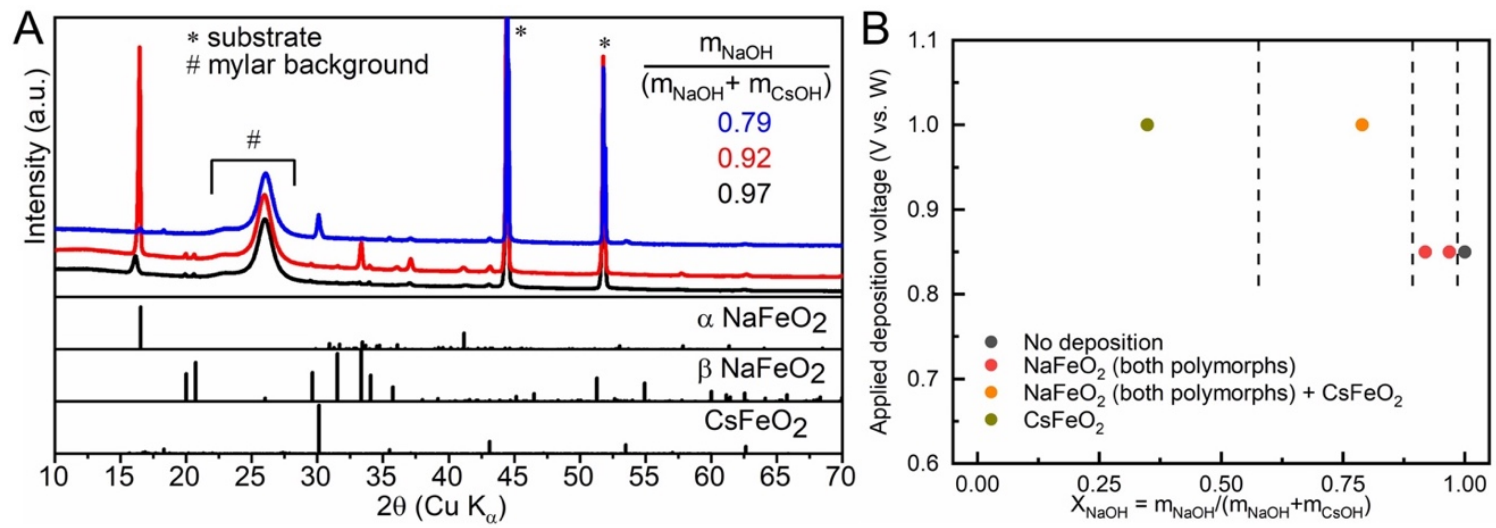

C

$\mathrm{Na}-\mathrm{Fe}-\mathrm{O}$ system

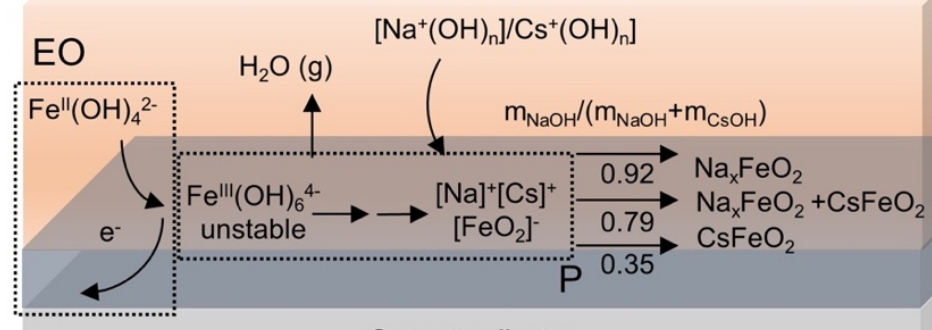

Current collector

Figure 5. Electrodeposition from Na-Fe-Cs-O system. A. XRD and B. Synthesis map created as a function of solvent basicity i.e. mole fraction of $\mathrm{NaOH}, \mathrm{X}_{\mathrm{NaOH}}=\mathrm{m}_{\mathrm{NaOH}} /\left(\mathrm{m}_{\mathrm{NaOH}}\right.$ $\left.+\mathrm{m}_{\mathrm{CsOH}}\right)$ and applied peak potential. Dotted lines are a guide to the eye. C. Schematic of the possible deposition mechanism of $\mathrm{Na}-\mathrm{Fe}-\mathrm{O}$ and $\mathrm{Cs}-\mathrm{Fe}-\mathrm{O}$ oxides as a function of $\mathrm{X}_{\mathrm{NaOH}}$. 

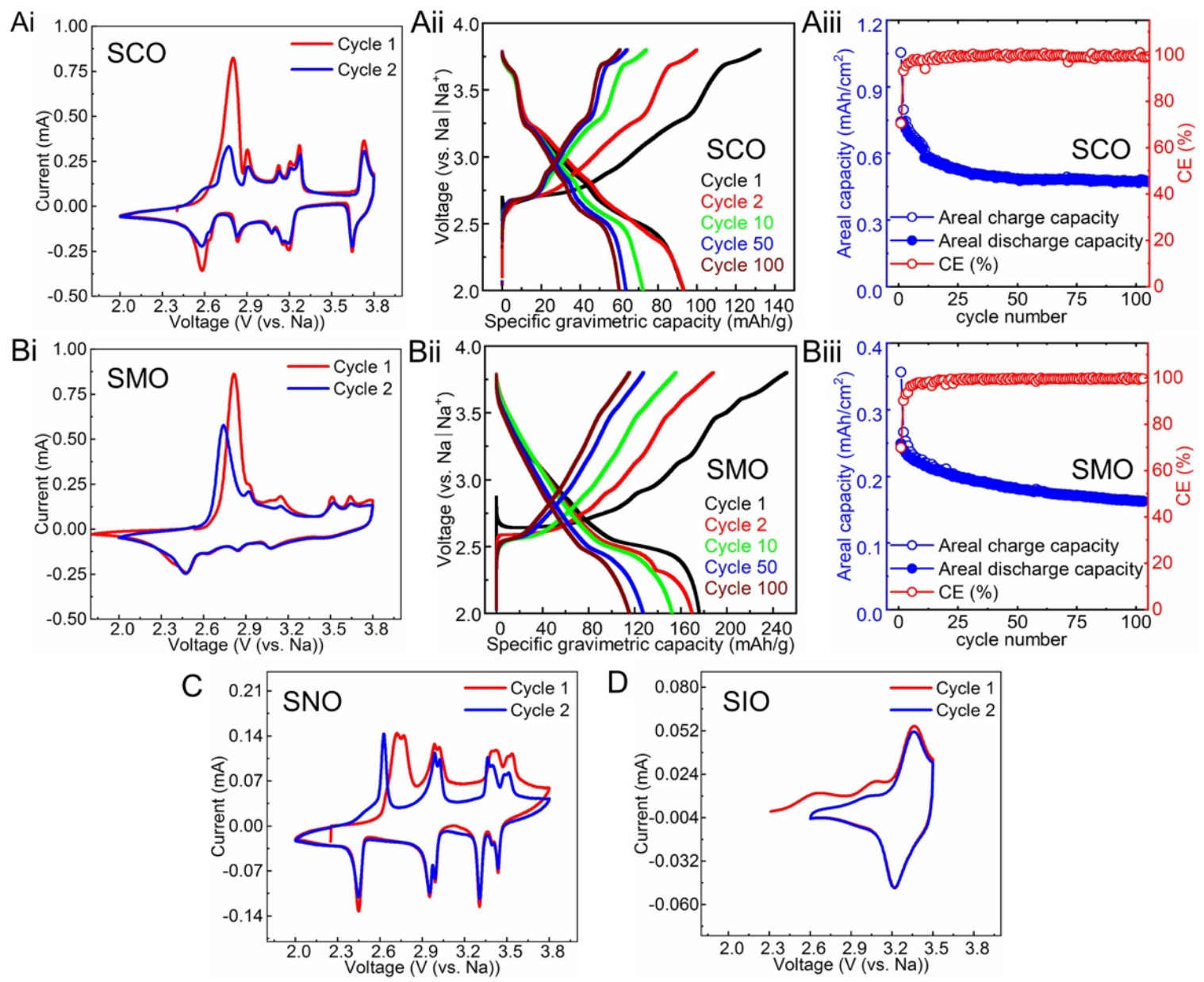

\section{Figure 6. Electrochemical performance of as synthesized electrodeposited} materials. $\mathrm{CV}$ at a sweep rate of $0.1 \mathrm{mV} / \mathrm{s}$ in the first and second cycle for $\mathrm{O} 3 \mathrm{Na}_{0.98} \mathrm{CoO}_{2}$ (SCO) (Ai), O'3 $\mathrm{Na}_{1.3} \mathrm{MnO}_{2+\mathrm{x}}(\mathrm{SMO})(\mathbf{B i}), \mathrm{O}^{\prime} 3 \mathrm{NaNiO}_{2}$ (SNO) (C), and O'3 alpha $\mathrm{NaFeO}_{2}$ (SIO) (D). Sodium intercalation and deintercalation profiles of $\mathrm{O} 3 \mathrm{Na}_{0.98} \mathrm{CoO}_{2}$ (Aii) and O'3 $\mathrm{Na}_{1.3} \mathrm{MnO}_{2+\mathrm{x}}(\mathrm{Bii})$ between 2-3.8 $\mathrm{V}$, at a charge and discharge rate of $\mathrm{C} / 10$. O3 $\mathrm{Na}_{0.98} \mathrm{CoO}_{2}$ has a loading of $8.0 \mathrm{mg} / \mathrm{cm}^{2}$ and a discharge current of $132 \mu \mathrm{A} / \mathrm{cm}^{2}$ is applied. O'3 $\mathrm{Na}_{1.3} \mathrm{MnO}_{2+\mathrm{x}}$ has a loading of $1.4 \mathrm{mg} / \mathrm{cm}^{2}$ and a discharge current of $35 \mu \mathrm{A} / \mathrm{cm}^{2}$ is applied. Aiii and Biii show cycling studies of $\mathrm{Na}_{0.98} \mathrm{CoO}_{2}$ and $\mathrm{O}^{\prime} 3 \mathrm{Na}_{1.3} \mathrm{MnO}_{2+\mathrm{x}}$ at a charge and discharge rate of $\mathrm{C} / 10$ for 100 cycles. E. A comparison of the areal discharge capacity and electrodeposited sodium cathodes 
Table 1. Optimized electrochemical processing parameters for $\mathrm{Na}-\mathrm{M}-\mathrm{O}(\mathrm{M}=\mathrm{Co}, \mathrm{Mn}$, $\mathrm{Ni}, \mathrm{Fe}$ ) systems

\begin{tabular}{|c|c|c|c|c|c|c|c|c|}
\hline System & Precursor & $\begin{array}{c}\mathrm{Na}^{+}: \mathrm{M}^{2+} \\
\text { molar } \\
\text { ratio }\end{array}$ & Electrolyte & $\begin{array}{c}\text { Synthesis } \\
\text { Temperature } \\
\left({ }^{\circ} \mathrm{C}\right)\end{array}$ & $\begin{array}{l}\text { Applied } \\
\text { voltage }\end{array}$ & Phase & $\begin{array}{c}\text { Loading } \\
\left(\mathrm{mg} / \mathrm{cm}^{2}\right) \\
(2 \mathrm{hr} \\
\text { deposition) }\end{array}$ & $\begin{array}{l}\text { Faradaic } \\
\text { efficiency }\end{array}$ \\
\hline $\mathrm{Na}-\mathrm{Co}-\mathrm{O}$ & $\begin{array}{c}\mathrm{Co}_{3} \mathrm{O}_{4} \\
(3.2 \mathrm{~g}-11.2 \mathrm{~g})\end{array}$ & $85-300$ & $\begin{array}{l}\mathrm{NaOH} \\
(160 \mathrm{~g})\end{array}$ & 350 & $\begin{array}{l}0.60-0.70 \\
\text { V (vs. Mo) }\end{array}$ & $\begin{array}{c}\mathrm{O} 3 \mathrm{Na}_{0.98} \mathrm{CoO}_{2} \\
(97 \%)\end{array}$ & $\begin{array}{l}28.0 \pm 3.3 \\
44.4 \pm 6.6\end{array}$ & $\begin{array}{l}45.0 \pm 4.0 \\
46.1 \pm 3.2\end{array}$ \\
\hline Na-Mn-O & $\begin{array}{c}\mathrm{Mn}_{3} \mathrm{O}_{4} \\
(3.04 \mathrm{~g})\end{array}$ & 300 & $\begin{array}{l}\mathrm{NaOH} \\
(160 \mathrm{~g})\end{array}$ & 350 & $\begin{array}{c}0.97 \mathrm{~V} \text { (vs. } \\
\text { W) }\end{array}$ & $\begin{array}{c}\mathrm{O}^{\prime} 3 \mathrm{Na}_{1.3} \mathrm{MnO}_{2+\mathrm{x}} \\
(95 \%)\end{array}$ & $11.0 \pm 1.4$ & $72.0 \pm-2.1$ \\
\hline $\mathrm{Na}-\mathrm{Ni}-\mathrm{O}$ & $\begin{array}{l}\mathrm{Ni}(\mathrm{OH})_{2} \\
(6.4 \mathrm{~g})\end{array}$ & 58 & $\begin{array}{l}\mathrm{NaOH} \\
(160 \mathrm{~g})\end{array}$ & 350 & $\begin{array}{c}1.20 \mathrm{~V} \text { (vs. } \\
\mathrm{W})\end{array}$ & $\mathrm{O}^{\prime} 3 \mathrm{Na}_{\mathrm{x}} \mathrm{NiO}_{2}$ & 1.4 & $1 \%$ \\
\hline $\mathrm{Na}-\mathrm{Fe}-\mathrm{O}$ & $\begin{array}{c}\mathrm{Fe}_{3} \mathrm{O}_{4} \\
(3.08 \mathrm{~g})\end{array}$ & 225 & $\begin{array}{c}\mathrm{NaOH} \\
(120 \mathrm{~g}): \\
\mathrm{CsOH} \\
(40 \mathrm{~g})\end{array}$ & 350 & $\begin{array}{c}0.85 \mathrm{~V} \text { (vs. } \\
\text { W) }\end{array}$ & $\begin{array}{c}\alpha(\mathrm{O} 3)+\beta(\mathrm{P} 2) \\
\mathrm{Na}_{\mathrm{x}} \mathrm{FeO}_{2}\end{array}$ & $<0.1$ & - \\
\hline
\end{tabular}


Supplementary Information for:

Electrodeposition of atmosphere-sensitive ternary sodium transition metal oxide films for sodium-based electrochemical energy storage

Arghya Patra ${ }^{1,2,3}$, Jerome Davis III ${ }^{2,3}$, Saran Pidaparthy ${ }^{1,2}$, Manohar H. Karigerasi ${ }^{1,2}$, Beniamin

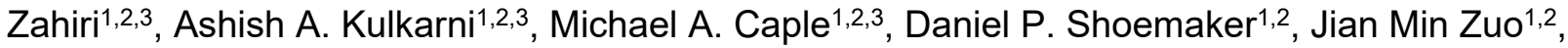
Paul V. Braun ${ }^{1,2,3,4^{*}}$

${ }^{1}$ Department of Materials Science and Engineering, University of Illinois at Urbana-Champaign, Illinois 61801, USA

${ }^{2}$ Materials Research Laboratory, University of Illinois at Urbana-Champaign, Illinois 61801, USA ${ }^{3}$ Beckman Institute for Advanced Science and Technology, University of Illinois at UrbanaChampaign, Illinois 61801, USA

${ }^{4}$ Department of Chemistry, University of Illinois at Urbana-Champaign, Illinois 61801, USA *email: pbraun@illinois.edu

Supplementary information text. SI1. Pourbaix diagram construction for $\mathrm{Na}-\mathrm{M}-\mathrm{O}-\mathrm{H}$ system at $350^{\circ} \mathrm{C}$.

Pourbaix diagrams for saturated baths of $\mathrm{Co}_{3} \mathrm{O}_{4}, \mathrm{Mn}_{3} \mathrm{O}_{4}, \mathrm{Ni}(\mathrm{OH})_{2}$, and $\mathrm{Fe}_{3} \mathrm{O}_{4}$ in a pure molten $\mathrm{NaOH}$ at $350^{\circ} \mathrm{C}$ are constructed, considering a Lux Flood acid base system based on reactions 1-5. Molten $\mathrm{NaOH}$ electrolyte is assumed to be an ideal solution (activity coefficient is unity). At the precursor concentration chosen (refer to Materials and methods, main text) the electrolyte is assumed to be saturated with the precursor.

The important chemical reactions from the $\mathrm{Na}-\mathrm{M}-\mathrm{O}-\mathrm{H}(\mathrm{M}=\mathrm{Co}, \mathrm{Mn}, \mathrm{Ni}, \& \mathrm{Fe})$ system coupled with a Na reference are as follows:

$$
\begin{array}{cr}
\mathrm{M}+\mathrm{NaOH}=\mathrm{MO}+\mathrm{H}_{2} \mathrm{O}+\mathrm{Na} & \text { Reaction } 1 \\
\text { from the half reactions } & \\
\mathrm{M}+2 \mathrm{OH}^{-}=\mathrm{MO}+\mathrm{H}_{2} \mathrm{O}+2 \mathrm{e} & (1 \mathrm{a}) \\
\mathrm{Na}+\mathrm{OH}^{-}=\mathrm{NaOH}+\mathrm{e} & (1 \mathrm{~b}) \\
3 \mathrm{MO}+2 \mathrm{NaOH}=\mathrm{M}_{3} \mathrm{O}_{4}+\mathrm{H}_{2} \mathrm{O}+2 \mathrm{Na} & \text { Reaction } 2 \\
\text { from the half reactions: } & (2 \mathrm{a}) \\
3 \mathrm{MO}+2 \mathrm{OH}^{-}=\mathrm{M}_{3} \mathrm{O}_{4}+\mathrm{H}_{2} \mathrm{O}+2 \mathrm{e} & (2 \mathrm{~b}) \\
\mathrm{Na}+\mathrm{OH}^{-}=\mathrm{NaOH}^{-\mathrm{e}} & \\
\mathrm{M}_{3} \mathrm{O}_{4}+4 \mathrm{NaOH}=3 \mathrm{NaMO}_{2}+2 \mathrm{H}_{2} \mathrm{O}+\mathrm{Na} & \text { Reaction 3 } \\
\text { from the half reactions: } &
\end{array}
$$




$$
\begin{gathered}
\mathrm{M}_{3} \mathrm{O}_{4}+3 \mathrm{Na}^{+}+4 \mathrm{OH}^{-}=3 \mathrm{NaMO}_{2}+2 \mathrm{H}_{2} \mathrm{O}+\mathrm{e} \\
\mathrm{Na}+\mathrm{OH}^{-}=\mathrm{NaOH}+\mathrm{e} \\
2 \mathrm{NaOH}=\mathrm{H}_{2} \mathrm{O}+1 / 2 \mathrm{O}_{2}+2 \mathrm{Na} \\
\text { from the half reactions: } \\
2 \mathrm{OH}^{-}=\mathrm{H}_{2} \mathrm{O}+1 / 2 \mathrm{O}+2 \mathrm{e} \\
\mathrm{Na}+\mathrm{OH}^{-}=\mathrm{NaOH}+\mathrm{e} \\
\mathrm{MO}+2 \mathrm{NaOH}=\mathrm{NaMO}_{2}+\mathrm{H}_{2} \mathrm{O}+\mathrm{Na} \\
\text { from the half reactions: } \\
\mathrm{MO}+\mathrm{Na}^{+}+2 \mathrm{OH}^{-}=\mathrm{NaMO}_{2}+\mathrm{H}_{2} \mathrm{O}+\mathrm{e} \\
\mathrm{Na}+\mathrm{OH}^{-}=\mathrm{NaOH}+\mathrm{e}
\end{gathered}
$$

Reaction 4

Reaction 5

The equations for construction of the Pourbaix diagrams are framed with respect to a $\mathrm{Na} \mid \mathrm{Na}^{+}$ couple based on the method described previously in (1). The equation number reflect the $\mathrm{pH}_{2} \mathrm{O}$ dependent redox line numbers shown in Fig. 2 (first column).

$$
\begin{gathered}
E_{1}=E_{1}^{*}+\frac{2.303 R T}{2 F} \log \frac{x_{\mathrm{MO}}}{x_{\mathrm{NaOH}}^{2}}-\frac{2.303 R T}{2 F} * p \mathrm{H}_{2} \mathrm{O} \\
E_{2}=E_{2}^{*}+\frac{2.303 R T}{2 F} \log \frac{1}{x^{3}{ }_{\mathrm{MO}} * x_{\mathrm{NaOH}}^{2}}-\frac{2.303 R T}{2 F} * p \mathrm{H}_{2} \mathrm{O} \\
E_{3}=E_{3}^{*}+\frac{2.303 R T}{F} \log \frac{1}{x_{\mathrm{NaOH}}^{4}}-2 * \frac{2.303 R T}{F} * p \mathrm{H}_{2} \mathrm{O} \\
E_{4}=E_{4}^{*}+\frac{2.303 R T}{2 F} \log \frac{P_{\mathrm{O}_{2}}{ }^{1 / 2}}{x_{\mathrm{NaOH}}^{2}}-\frac{2.303 R T}{2 F} * p \mathrm{H}_{2} \mathrm{O} \\
E_{5}=E_{5}^{*}+\frac{2.303 R T}{F} \log \frac{1}{x_{\mathrm{MO}} * x_{\mathrm{NaOH}}^{2}}-\frac{2.303 R T}{2 F} * p \mathrm{H}_{2} \mathrm{O}
\end{gathered}
$$

Since Pourbaix diagrams are strictly thermodynamic constructs, inferences should be drawn considering the assumptions. The implicit assumptions include that the electrodeposition process is Nernstian i.e., not kinetically limited. This may be a good assumption considering the high temperature of synthesis, fast kinetics of the reaction and electronic conductivity of the deposited material. The current magnitudes are 'high' (Fig. S1) to indicate that there are no significant kinetic limitations. The overvoltage for the deposition is assumed to be low enough to operate in a nearequilibrium condition and prevent formation of over-intercalated structures and/ metastable phases which are not considered for constructing the diagram. There exist two polymorphs for $\mathrm{NaMO}_{2}$ with a Jahn Teller active center (as in $\left.\mathrm{Mn}, \mathrm{Fe}, \mathrm{Ni}\right)$ with one high temperature $\left(\sim 800^{\circ} \mathrm{C}\right)$ 
metastable phase (commonly called beta polymorph) and one low temperature $\left(\sim 500-600^{\circ} \mathrm{C}\right)$ thermodynamically stable polymorph (commonly called alpha polymorph). The thermodynamically stable low temperature polymorph is used for Gibbs energy calculation for $\mathrm{NaMnO}_{2}, \mathrm{NaNiO}_{2}$ and $\mathrm{NaFeO}_{2}$. Transition metal oxyhydroxides are not chosen for the construction of the Pourbaix diagram due to their thermal instability at $350^{\circ} \mathrm{C}$.

The electrochemical potential observed at the anodic electrolyte decomposition will be associated with some kinetic overpotential. In the Pourbaix diagrams, the apparent potentials in molten $\mathrm{NaOH}$ are calculated with respect to $\mathrm{Na|} \mathrm{Na}^{+}$and converted to the pseudo-reference scale with a Mo and W wire, based on the experimentally observed anodic electrolytic decomposition of pure molten $\mathrm{NaOH}$. This reaction experimentally occurs at $2.260 \mathrm{~V}$ (vs. $\mathrm{Na|Na}$ ) (2) under identical experimental conditions ( $\mathrm{Ni} \mathrm{WE}$, molten $\mathrm{NaOH}$ at $350^{\circ} \mathrm{C}$ ), which is equivalent to $1.04 \mathrm{~V}$ (vs. Mo), and 1.22 (V vs. W). This is how the right $y$ axis $V($ Mo or $W$ ) is scaled with the left y axis $\mathrm{V}$ (vs. $\mathrm{Na} \mid \mathrm{Na}^{+}$) for the Pourbaix diagrams (Fig. 2, first column). Tungsten, Molybdenum and Cobalt wires can all be used as pseudo-reference electrodes for deposition in the Na-M-O-H (M $=\mathrm{Co}, \mathrm{Ni}, \mathrm{Mn}, \mathrm{Fe})$ hydroxide systems discussed in the dry and $\mathrm{O}_{2}$-free state $\left(\mathrm{O}_{2}<10 \mathrm{ppm}\right)$. The choice of $\mathrm{W}$ and Mo stems from their prior application as pseudo reference electrodes in other dry molten chloride systems (3) (4). Voltages measured with respect to a Mo and a W reference electrode are related by $\mathrm{V}_{\text {(with Mo) }}+\sim 0.18 \mathrm{~V}=\mathrm{V}_{\text {(with } \mathrm{w} \text { ). }}$ Please read MSDS carefully for safe handling of molten hydroxides.

Table S1. Thermodynamic data used for construction of the Na-M-O-H Pourbaix diagram ( $\mathrm{M}=$ $\mathrm{Co}, \mathrm{Mn}, \mathrm{Ni}, \mathrm{Fe})$ system at $350^{\circ} \mathrm{C}$.

\begin{tabular}{|c|c|}
\hline Species & Gibbs energy (kJ/mol) \\
\hline $\mathrm{Na}^{*}$ & -37.931 \\
\hline $\mathrm{NaOH}^{*}$ & -475.924 \\
\hline $\mathrm{H}_{2} \mathrm{O}^{*}$ & -364.200 \\
\hline $\mathrm{O}_{2}^{*}$ & -131.977 \\
\hline $\mathrm{Co}^{*}$ & -22.299 \\
\hline $\mathrm{Mn}^{*}$ & -23.758 \\
\hline $\mathrm{Ni}^{*}$ & -22.465 \\
\hline $\mathrm{Fe}^{*}$ & -20.698 \\
\hline $\mathrm{CoO}^{*}$ & -278.242 \\
\hline
\end{tabular}




\begin{tabular}{|l|l}
\hline $\mathrm{MnO}^{*}$ & -428.765 \\
\hline $\mathrm{NiO}^{*}$ & -270.358 \\
\hline $\mathrm{FeO}^{*}$ & -316.901 \\
\hline $\mathrm{Co}_{3} \mathrm{O}_{4}{ }^{*}$ & -2000.309 \\
\hline $\mathrm{Mn}_{3} \mathrm{O}_{4}{ }^{*}$ & -1505.481 \\
\hline $\mathrm{Fe}_{3} \mathrm{O}_{4}{ }^{*}$ & -1232.977 \\
\hline $\mathrm{NaCoO}_{2}{ }^{* *}$ & -616.755 \\
\hline $\mathrm{NaMnO}_{2}{ }^{* *}$ & -784.050 \\
\hline $\mathrm{NaNiO}_{2}{ }^{* *}$ & -469.504 \\
\hline $\mathrm{NaFeO}_{2}{ }^{* *}$ & -747.044 \\
\hline
\end{tabular}

*The values for pure substances are taken from (5).

${ }^{* *}$ Heat of formation at standard state is used due to lack of information on specific heat capacity of the layered sodium cathodes. 
A
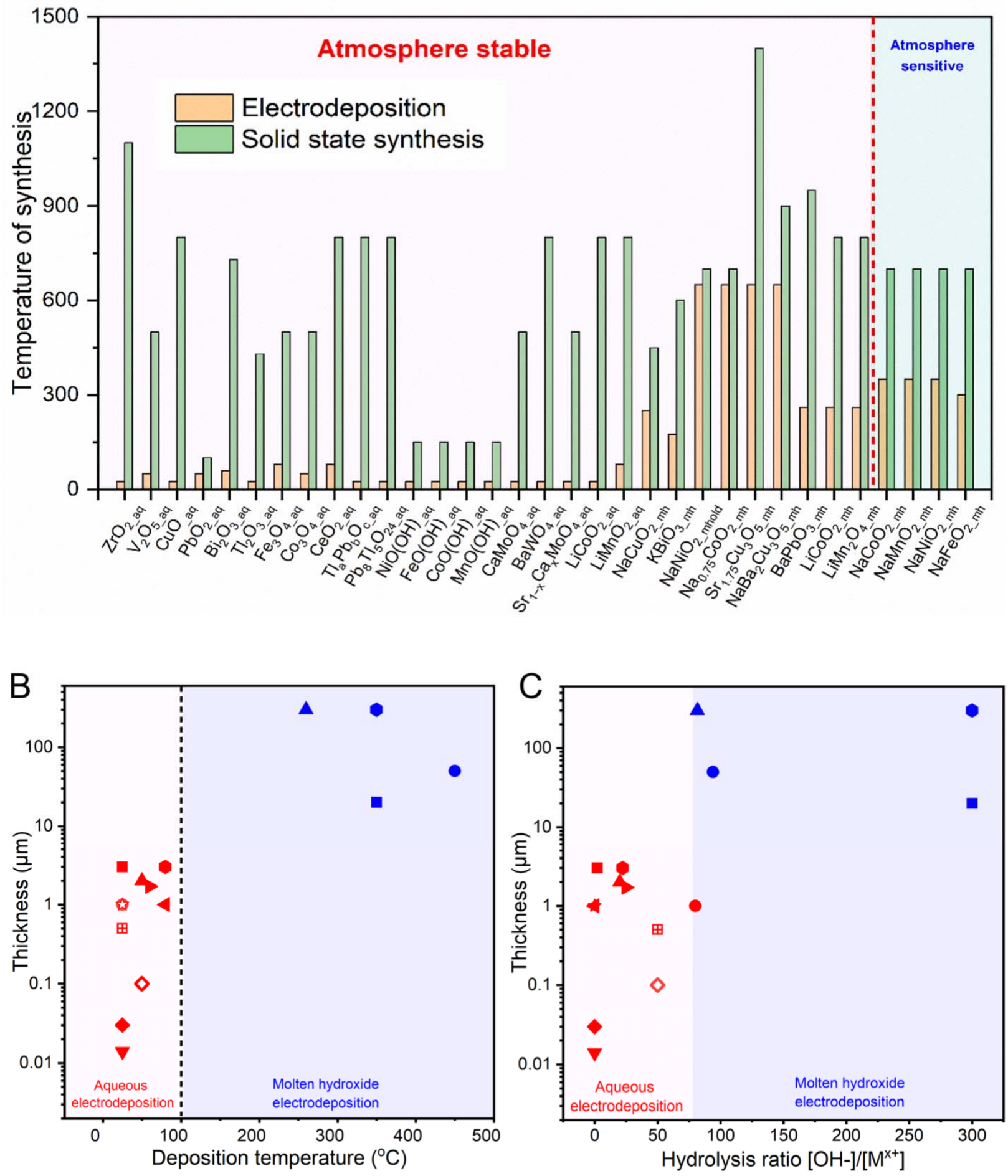

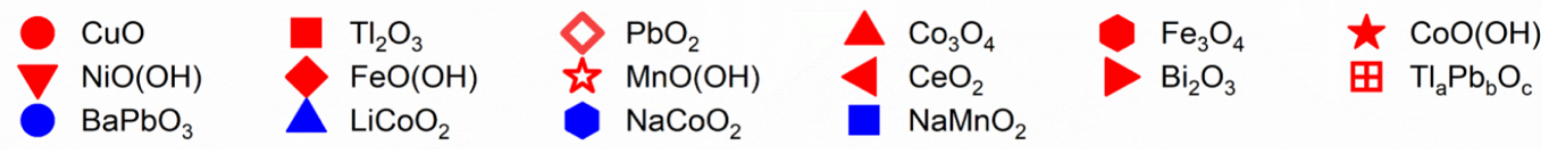


Fig. S1A. Summary of synthesis temperatures of electrodeposited oxide/oxyhydroxides by anodic electrolytic deposition (orange) and solid-state synthesis (green). Role of hydrolysis ratio (S1B) and temperature of deposition (S1C) on thickness of the electrodeposit. Data is compiled from

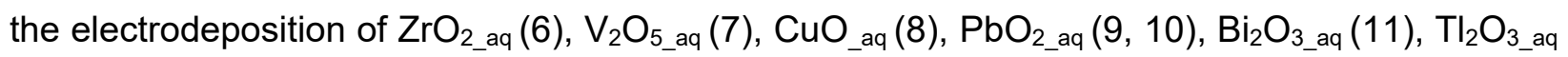

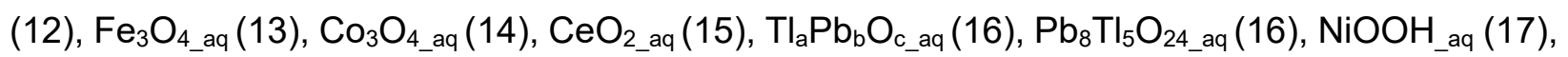
$\mathrm{CoOOH}_{\_}$aq $(18), \mathrm{MnOOH}_{-}$aq $(19), \mathrm{FeOOH}_{-}$aq, $\mathrm{CaMoO}_{4}$ aq $(20), \mathrm{BaWO}_{4}$ aq $(21), \mathrm{Sr}_{1-\mathrm{x}} \mathrm{Ca}_{\times} \mathrm{MoO}_{4}$ aq (20), $\mathrm{LiCoO}_{2 \_ \text {aq }}(22,23), \mathrm{LiMnO}_{2}$ aq, $\mathrm{NaCuO}_{2}$ mh $(24), \mathrm{KBiO}_{3 \_m h}, \mathrm{NaNiO}_{2 \_m h}(25), \mathrm{NaO}_{.75} \mathrm{CoO}_{2 \_m h}$ (25), $\mathrm{Sr}_{1.75} \mathrm{Cu}_{3} \mathrm{O}_{5} \_\mathrm{mh}(25), \mathrm{BaPbO}_{3}$ mh $(26), \mathrm{LiCoO}_{2}$ mh $(1), \mathrm{LiMn}_{2} \mathrm{O}_{4} \_\mathrm{mh}(1), \mathrm{NaCoO}_{2}$ mh (this work), $\mathrm{NaMnO}_{2}$ mh (this work), $\mathrm{NaFeO}_{2 \_m h}$ (this work), $\mathrm{NaNiO}_{2 \_m h}$ (this work). The subscript indicates the growth method. The thickness of the deposits grown as films are summarized in fig. S1B and fig. S1C. The dotted line in Fig. S1B indicates the temperature limit of the aqueous based electrosynthesis i.e., boiling point of water $\left(100^{\circ} \mathrm{C}\right)$. We observe that a high hydrolysis ratio $(>75)$ and high temperature $\left(>250^{\circ} \mathrm{C}\right)$ synergistically benefit the growth of thicker electrodeposits. 
Table S2. Comparison of peaks observed in the cyclic voltammetry experiments in $\mathrm{Na}$ half-cell for solid state synthesized STMOs and the corresponding electrodeposited STMOs at a scan rate of $0.1 \mathrm{mV} / \mathrm{s}$. The values are picked from Fig. $\mathbf{5}(\mathbf{A i}, \mathbf{B i}, \mathbf{C}, \mathbf{D})$ in the main text.

\begin{tabular}{|c|c|c|c|}
\hline Reference & Material & Oxidation peaks & Reduction peaks \\
\hline This work & $\begin{array}{l}\text { Electrodeposited } \\
\mathrm{Na}_{\times} \mathrm{MnO}_{2} \\
\end{array}$ & $\begin{array}{c}2.73,2.91,3.02,3.14, \\
3.51,3.62 \\
\end{array}$ & $\begin{array}{c}2.47,2.62,2.84,2.94,3.07 \\
3.48\end{array}$ \\
\hline$(27)$ & $\begin{array}{l}\text { Solid state O'3 } \\
\qquad \mathrm{NaMnO}_{2}\end{array}$ & $\begin{array}{c}(2.59,2.63,2.73,2.80) \\
\text { broad plateau } 2.97,3.14, \\
3.48 \text { and } 3.59\end{array}$ & $\begin{array}{c}2.47,2.62,2.87,3.08 \\
3.45 \mathrm{~V}\end{array}$ \\
\hline This work & $\begin{array}{l}\text { Electrodeposited } \\
\qquad \mathrm{Na}_{\mathrm{x}} \mathrm{CoO}_{2}\end{array}$ & $\begin{array}{c}2.54,2.70,2.87,3.10 \\
3.19,3.26,3.71\end{array}$ & $\begin{array}{c}2.51,2.63,2.79,3.06,3.14 \\
3.19,3.62\end{array}$ \\
\hline (28) & $\begin{array}{l}\text { Solid state } \mathrm{O} 3 \\
\mathrm{NaCoO}_{2} \\
\end{array}$ & $\begin{array}{c}2.56,2.73,2.89,3.13 \\
3.24,3.71,3.90 \\
\end{array}$ & \\
\hline This work & $\begin{array}{l}\text { Electrodeposited } \\
\qquad \mathrm{Na}_{\mathrm{x}} \mathrm{NiO}_{2}\end{array}$ & $\begin{array}{c}2.63,2.97,3.04,3.37 \\
\quad 3.40,3.48,3.51\end{array}$ & $\begin{array}{c}2.43,2.95,2.98,3.30,3.39 \\
3.44\end{array}$ \\
\hline (29) & $\begin{array}{l}\text { Solid state O'3 } \\
\quad \mathrm{NaNiO}_{2}\end{array}$ & $2.7,3.1,3.4,3.5$ & $2.3,2.9,3.2,3.4$ \\
\hline This work & $\begin{array}{c}\text { Electrodeposited } \\
\mathrm{Na}_{\mathrm{x}} \mathrm{FeO}_{2}\end{array}$ & 3.35 & 3.22 \\
\hline (30) & $\begin{array}{c}\text { Solid state } \mathrm{O} 3 \\
\mathrm{NaFeO}_{2} \\
\end{array}$ & $\sim 3.3$ & $\sim 3.3$ \\
\hline
\end{tabular}


Table S3A. Rietveld refinement parameters of as-synthesized electrodeposit at $0.6 \mathrm{~V}$ (vs Mo) from $2.0 \mathrm{w} / \mathrm{w} \%$ of $\mathrm{Co}_{3} \mathrm{O}_{4}$ in $\mathrm{NaOH}$ at $350^{\circ} \mathrm{C}$.

\begin{tabular}{|c|c|c|}
\hline & As electrodeposited SCO & $\begin{array}{c}\text { Solid state synthesized } \\
\text { [ref :(28)] }\end{array}$ \\
\hline Synthesis condition & $\begin{array}{c}(0.6 \mathrm{~V} \text { vs } \mathrm{Mo}, 0.25 \mathrm{~s} \text { on } 8 \mathrm{~s} \text { off, } 2 \\
\text { hours plating } 2 \text { hours } \\
\text { equilibration in solution with } 2.0 \\
\text { w/w } \% \mathrm{Co}_{3} \mathrm{O}_{4}(3.2 \mathrm{~g}) \text { in } 160 \mathrm{~g} \\
\mathrm{NaOH}\end{array}$ & $\begin{array}{l}\mathrm{Na}_{2} \mathrm{O}_{2} \text { and } \mathrm{Co}_{3} \mathrm{O}_{4} \text { in a molar } \\
\text { ratio of } 1.05: 1 \text { at } 450-900^{\circ} \mathrm{C}\end{array}$ \\
\hline Temperature of synthesis & 350 & $450-550$ \\
\hline $\mathrm{Na}^{+}: \mathrm{Co}^{2+}$ molar ratio & $300: 1$ & $1.05: 1$ \\
\hline Phases & $\mathrm{O} 3 \mathrm{NaCoO}_{2}(97 \%)+\mathrm{O} 3(3 \%)$ & $\mathrm{O} 3 \mathrm{NaCoO}_{2}$ \\
\hline $\begin{array}{l}\text { Space group for } \mathrm{O} 3 \\
\text { phase }\end{array}$ & $\mathrm{R} \overline{3} \mathrm{~m}$ (No. 166) & R̄̄m (No. 166) \\
\hline $\begin{array}{l}\text { Unit cell parameters for } \\
\text { O3 phase }\end{array}$ & $\begin{array}{c}a=b=2.8855(5) \AA \\
c=15.6087(9) \AA\end{array}$ & $\begin{array}{c}a=b=2.8883 \\
c=15.6019\end{array}$ \\
\hline Volume $\left(\AA^{3}\right)$ & 112.553 & 112.718 \\
\hline $\mathrm{d}_{003}(\AA)$ & 5.2029 & 5.200 \\
\hline Co-O bond length $(\AA)$ & $1.92(6 x)$ & \\
\hline Na-O bond length $(\AA)$ & $2.34(6 x)$ & \\
\hline $\mathrm{R}_{\mathrm{p}}, \mathrm{R}_{\mathrm{wp}}, \mathrm{R}_{\mathrm{exp}}, \mathrm{GOF}$ & $9.04,12.27,3.02,4.07$ & \\
\hline
\end{tabular}


Table S3B. Rietveld refinement parameters of as-synthesized electrodeposit at $0.97 \mathrm{~V}$ (vs W) from $3.04 \mathrm{~g} \mathrm{Mn}_{3} \mathrm{O}_{4}$ in $160 \mathrm{~g} \mathrm{NaOH}$ at $350^{\circ} \mathrm{C}$.

\begin{tabular}{|c|c|c|}
\hline & As electrodeposited SMO & Solid state synthesized [ref:(31)] \\
\hline Synthesis condition & $\begin{array}{c}(0.97 \mathrm{~V} \text { vs } \mathrm{W}, 0.25 \mathrm{~s} \text { on } 8 \mathrm{~s} \text { off, } \\
2 \text { hours plating } 2 \text { hours } \\
\text { equilibration in solution with } \\
3.04 \mathrm{~g} \mathrm{Mn}_{3} \mathrm{O}_{4} \text { in } 160 \mathrm{~g} \mathrm{NaOH}\end{array}$ & $\begin{array}{c}\mathrm{Na}_{2} \mathrm{CO}_{3} \text { and } \mathrm{Mn}_{2} \mathrm{O}_{3} \text { at } 700^{\circ} \mathrm{C} \text { for } 10 \\
\text { hours }\end{array}$ \\
\hline $\begin{array}{c}\text { Temperature of } \\
\text { synthesis }\end{array}$ & $350^{\circ} \mathrm{C}$ & $700^{\circ} \mathrm{C}$ \\
\hline $\mathrm{Na}^{+}: \mathrm{Mn}^{2+}$ molar ratio & $300: 1$ & stoichiometric \\
\hline Phases & $\begin{array}{c}\text { O'3 Alpha } \mathrm{Na}_{1.3} \mathrm{MnO}_{2+\mathrm{x}} \\
(94.56 \%)+\text { Beta } \mathrm{NaMnO}_{2} \\
(1.99 \%)+\text { Cmcm Na }{ }_{67} \mathrm{MnO}_{2} \\
(3.45 \%)\end{array}$ & O'3 Alpha $\mathrm{Na}_{1} \mathrm{MnO}_{2}$ \\
\hline $\begin{array}{c}\text { Space group for alpha } \\
\text { O'3 phase }\end{array}$ & $\mathrm{C} 2 / \mathrm{m}$ & $\mathrm{C} 2 / \mathrm{m}$ \\
\hline $\begin{array}{l}\text { Unit cell parameters for } \\
\text { alpha O'3 phase }\end{array}$ & $\begin{array}{l}a=5.6777(6) \AA, b=2.8571(6) \\
\AA, c=5.7597(9) \AA, \beta=113.06^{\circ}\end{array}$ & $\begin{array}{c}a=5.672 \AA, b=2.856 \AA, c=5.807 \\
\AA, \beta=113.2^{\circ} .\end{array}$ \\
\hline Mn-O bond length & $2.38 \AA(2 x), 1.93 \AA(4 x)$ & $2.39 \AA(2 x), 1.94 \AA(4 x)$ \\
\hline $\mathrm{Na}-\mathrm{O}$ bond length & $2.42 \AA(2 x), 2.34 \AA(4 x)$ & \\
\hline $\mathrm{R}_{\mathrm{p}}, \mathrm{R}_{\mathrm{wp}}, \mathrm{R}_{\mathrm{exp}}, \mathrm{GOF}$ & $16.37,21.46,3.34,6.42$ & \\
\hline
\end{tabular}


Table S4. ICP data for as electrodeposited A) SCO and B) SMO.

\begin{tabular}{c|c|c|c}
\hline \hline \multicolumn{1}{c}{ Atom } & Theoretical & Found & Diff \\
\hline \hline $\mathrm{Co}$ & 51.73 & 50.07 & 1.66 \\
\hline $\mathrm{Na}$ & 20.18 & 19.12 & 1.06 \\
\hline
\end{tabular}

Na: Co molar ratio $=0.98: 1.0$

\begin{tabular}{c|c|c|c}
\hline \hline Atom & Theoretical & Found & Diff \\
\hline \hline $\mathrm{Mn}$ & 49.98 & 43.02 & -6.96 \\
\hline $\mathrm{Na}$ & 20.91 & 23.79 & 2.88 \\
\hline
\end{tabular}

Na: Mn molar ratio $=1 \cdot 3: 1 \cdot 0$ 


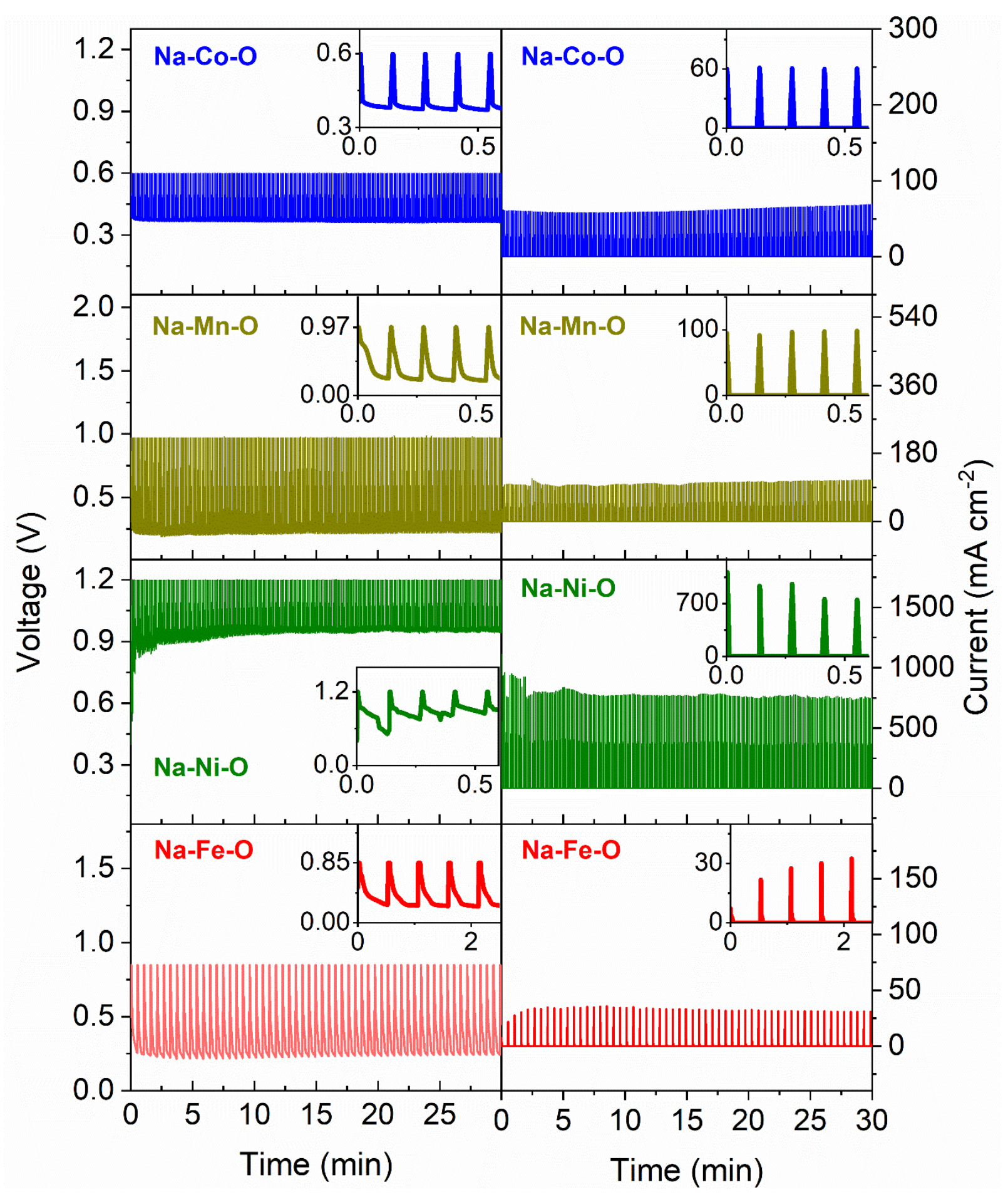

Fig. S2. Current and voltage profiles for the deposition parameters for each system enlisted in Table 1 (main text). Current magnitudes are of the order of $\left(60 \mathrm{~mA} / \mathrm{cm}^{2}\right.$ for Na-Co-O and 95 $\mathrm{mA} / \mathrm{cm}^{2}$ for Na-Mn-O system, $\sim 620 \mathrm{~mA} / \mathrm{cm}^{2}$ for Na-Ni-O, and $\sim 30 \mathrm{~mA} / \mathrm{cm}^{2}$ for Na-Fe-O). 


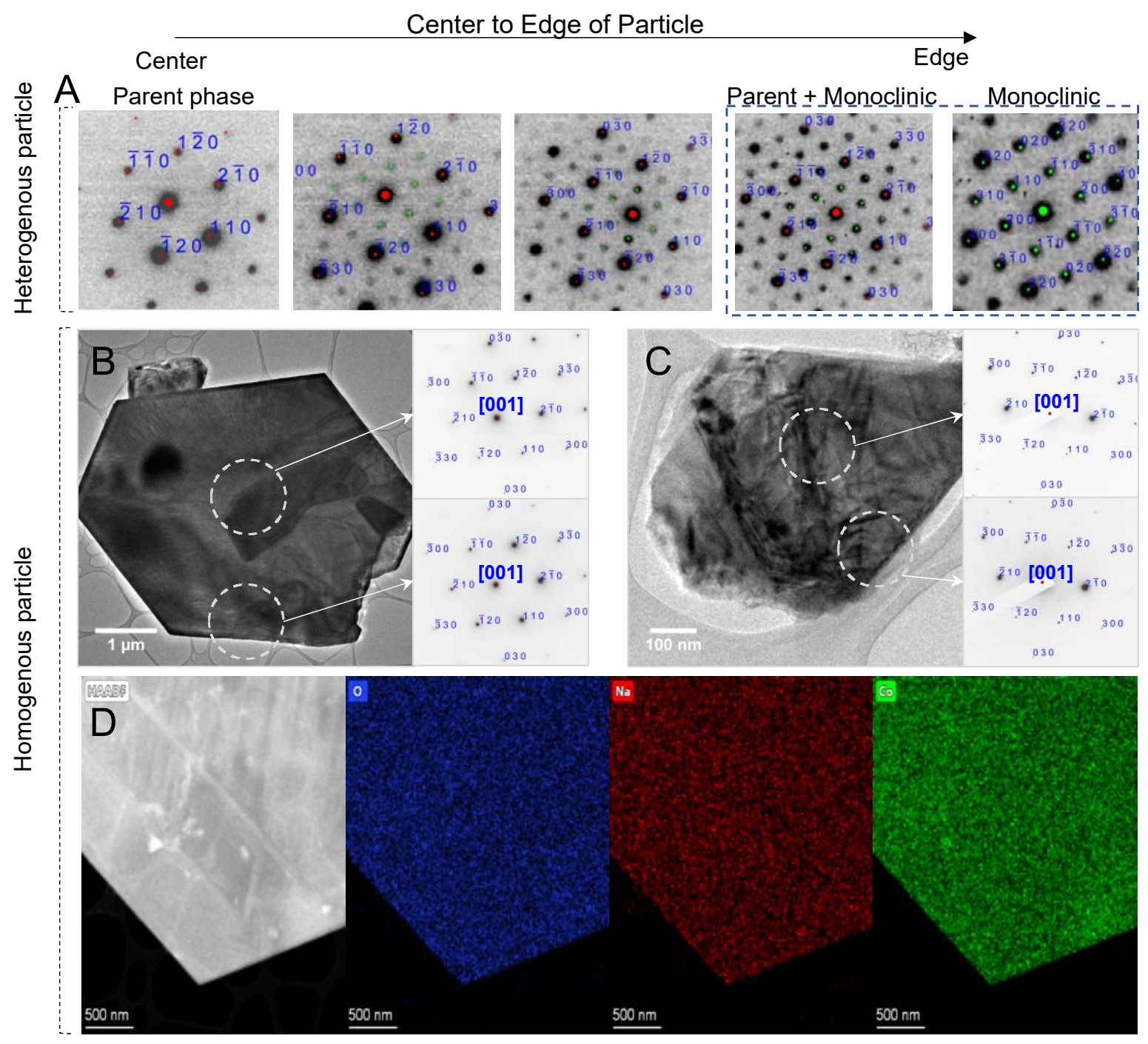

Fig. S3. TEM analysis of as electrodeposited SCO. Fig. S3A indicates the indexed diffraction patterns of the biphasic platelet shown in Fig. 3 across the thickness of the platelet from center to edge. Parent phase at the center is indexed (with red dots) in a R $\overline{3} \mathrm{~m}$ space group (ICSD 04010-6377) $a, b=2.88970 \AA, c=15.60190 \AA$ with a zone axis of [001]. The monoclinic phase at the edge (lime green dots) is extracted from R $\overline{3} \mathrm{~m}$ (ICSD 04-010-6377) with parameters a $=4.8912$ $\AA, b=2.8681 \AA, c=5.7937 \AA$, beta $=111^{\circ}$ with a zone axis of [001]. Holding the electrodeposited $\mathrm{SCO}$ in molten $\mathrm{NaOH}$ homogenize the particles in terms of structural composition with $\mathrm{O} 3$ phases present at the edge and the center for big particles with edge length $5 \mu \mathrm{m}$ (Fig. 3B) and small particles with edge length $250 \mathrm{~nm}$ (Fig. S3C). Fig. S3D indicates the STEM EDS for O (blue), Na (red) and Co (green) to further corroborate the chemical homogeneity of electrodeposited samples held at molten $\mathrm{NaOH}\left(350^{\circ} \mathrm{C}\right)$ for 2 hours post electrodeposition. 
A

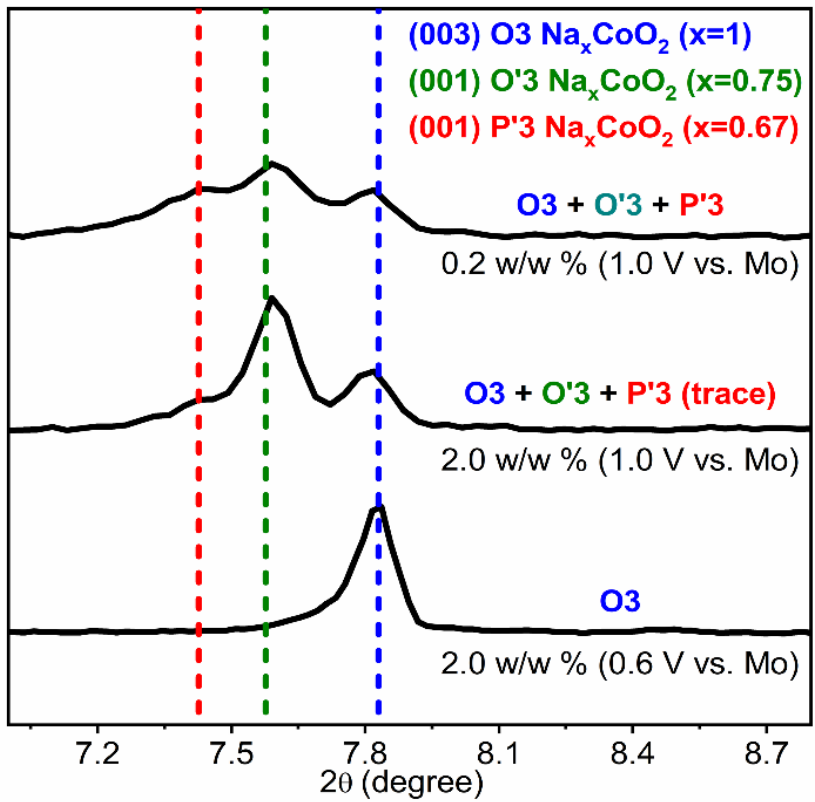

\section{C}

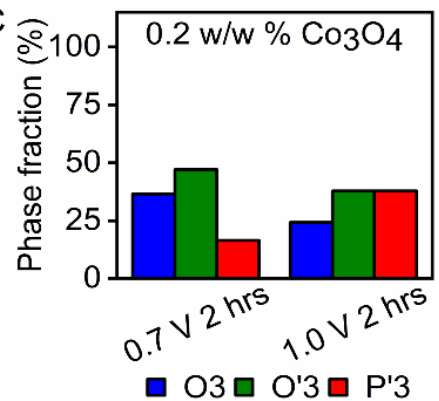

F

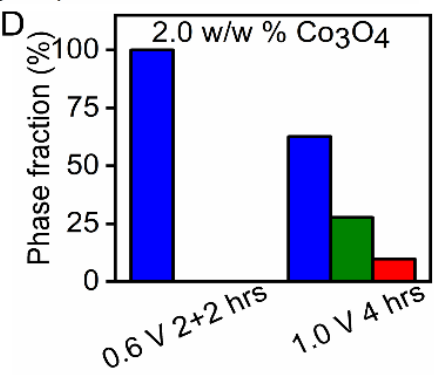

B

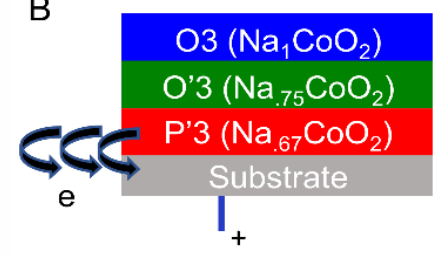

$\mathrm{O} 3\left(\mathrm{Na}_{1} \mathrm{CoO}_{2}\right)$

$\mathrm{O}^{\prime} 3\left(\mathrm{Na}_{.75} \mathrm{CoO}_{2}\right)$

e

Substrate

I
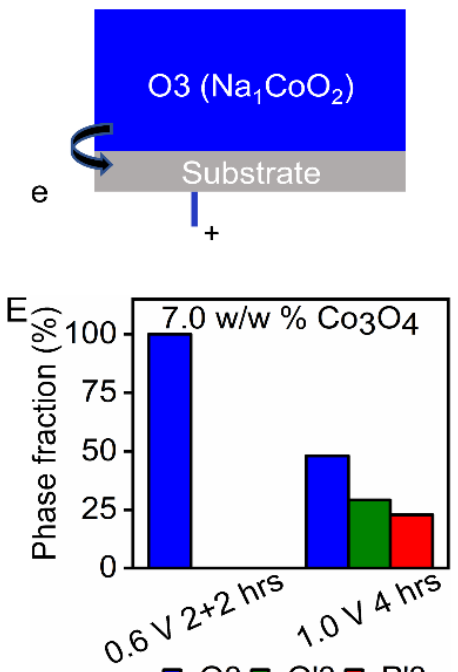

๑ O3ם O'3ם P'3

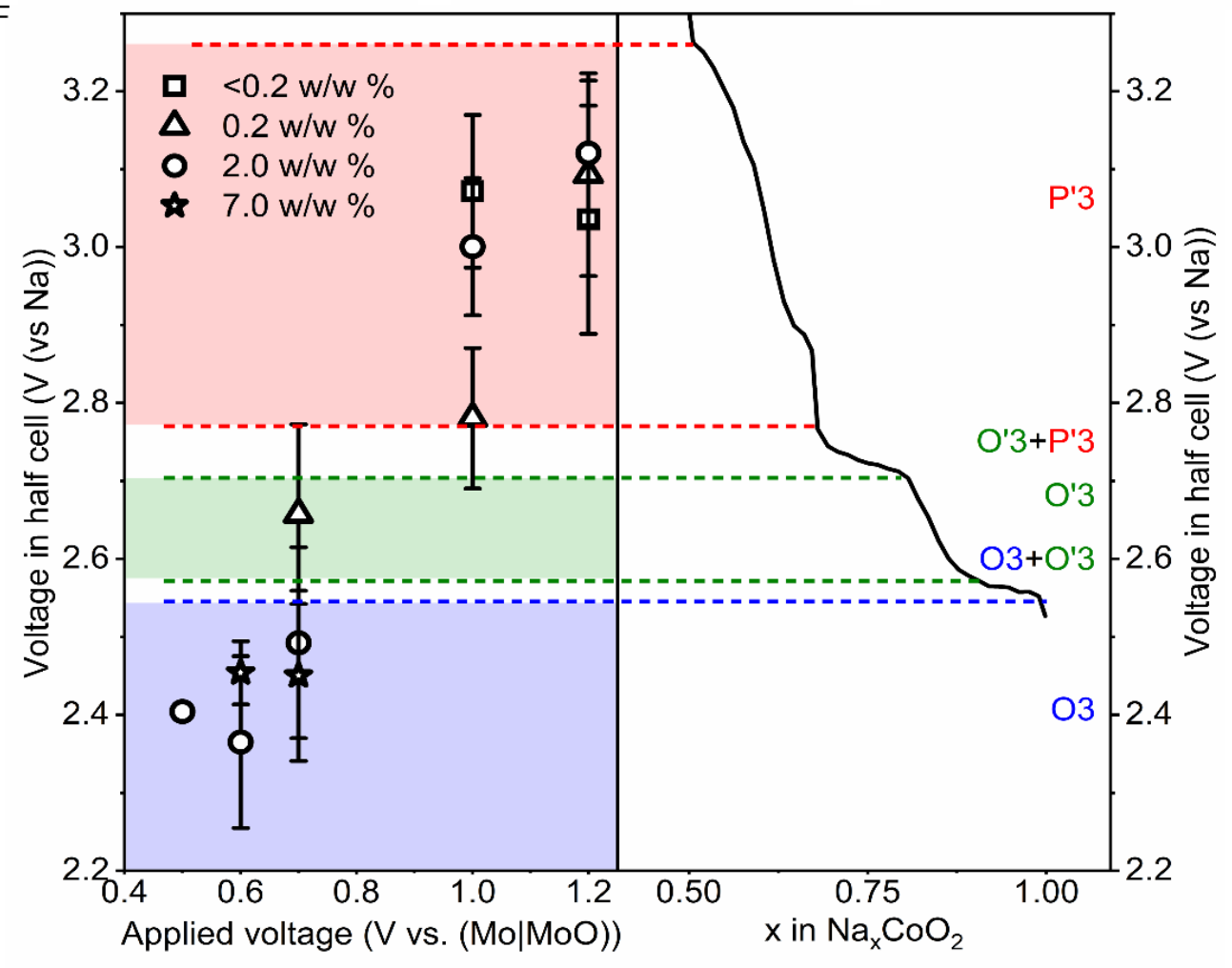


Fig. S4. Construction of the synthesis diagram in Na-Co-O system. Fig. S4A shows the concomitant charging (desodiation) effect during electrodeposition in Na-Co-O system. Indicative peaks of the $\mathrm{O} 3$ (003) (marked in blue), O'3 (001) (marked in green) and P'3 (001) (marked in red) is shown in the X Ray diffractograms (Mo Kalpha). This color code is used for all O3, O'3 and P'3 phases discussed here. Synergistic effect of applied peak potential and precursor concentration leads to gradual phase transition from $\mathrm{O} 3\left(2.0 \mathrm{w} / \mathrm{w} \% \mathrm{Co}_{3} \mathrm{O}_{4}, 0.6 \mathrm{~V}\right.$ vs. Mo), $\mathrm{O} 3+$ O'3 (2.0 w/w \% $\mathrm{Co}_{3} \mathrm{O}_{4}, 1.0 \mathrm{~V}$ vs. Mo), and $\mathrm{O}^{\prime}+\mathrm{O}^{\prime} 3+\mathrm{P}^{\prime} 3\left(0.2 \mathrm{w} / \mathrm{w} \% \mathrm{Co}_{3} \mathrm{O}_{4}, 1.0 \mathrm{~V} \mathrm{vs}\right.$. Mo) for same deposition times. This is schematically illustrated in Fig. S4B. The phase fraction present in the electrodeposits from Na-Co-O system are illustrated in Fig. S4C, S4D, and S4E for precursor concentrations of $0.2 \mathrm{w} / \mathrm{w} \quad \mathrm{CO}_{3} \mathrm{O}_{4}, 2.0 \mathrm{w} / \mathrm{w} \quad \mathrm{Co}_{3} \mathrm{O}_{4}$, and $7.0 \mathrm{w} / \mathrm{w} \% \mathrm{Co}_{3} \mathrm{O}_{4}$ respectively at different applied voltages. A closer look at the current vs. time profiles during the rest interval provides important insight into whether a longer toff time would result in a $\mathrm{Na}_{x} \mathrm{CoO}_{2}$ with a $\mathrm{x}$ close to 1 . As we mention in the main text and show in Fig. S2, the depositions are conducted (with the $t_{\text {on }}$ time of $0.25 \mathrm{~s}$ and $t_{\text {off }}$ time of $8 \mathrm{~s}$ ) in an activation-controlled regime. Thus, instead of letting the system "relax" more with chemical sodiation during a longer $t_{\text {off }}$ time, to generate a single phase $\mathrm{O3}$, we experimentally choose conditions which are close to "equilibrium", such as low overpotential for $\mathrm{Co}^{2+}$ oxidation and high precursor concentration. This is best illustrated in Fig. S4D and S4E where high precursor concentrations of $2.0-7.0 \mathrm{w} / \mathrm{w} \%$ and at applied peak potentials $\left(0.6 \mathrm{~V}\right.$ vs. Mo) with a low overpotential with $\mathrm{Co}^{2+} \mid \mathrm{Co}^{3+}$ redox at $\sim 0.45 \mathrm{~V}$ vs $\mathrm{Mo}$ ) we see phase pure $\mathrm{O} 3 \mathrm{Na}_{1} \mathrm{CoO}_{2}$. As we move to more "non equilibrium conditions" with low precursor concentrations $(0.2 \mathrm{wt} \%)$ and higher applied overpotentials, $(1.0 \mathrm{~V}$ and $1.2 \mathrm{~V}$ vs Mo) we see appearance of partially charged phases with higher phase fraction as elucidated in Fig. S4C. Fig. S4F shows how the electrochemical potential in half-cell (vs. $\mathrm{NaINa}^{+}$) for the electrodeposits is compared to the deintercalation profile of a solid state synthesized $\mathrm{O} 3 \mathrm{NaCoO}_{2}$ (32) and attributed to the phase(s) present. This is corroborated with XRD analysis to construct the phase map in Fig. 3. 

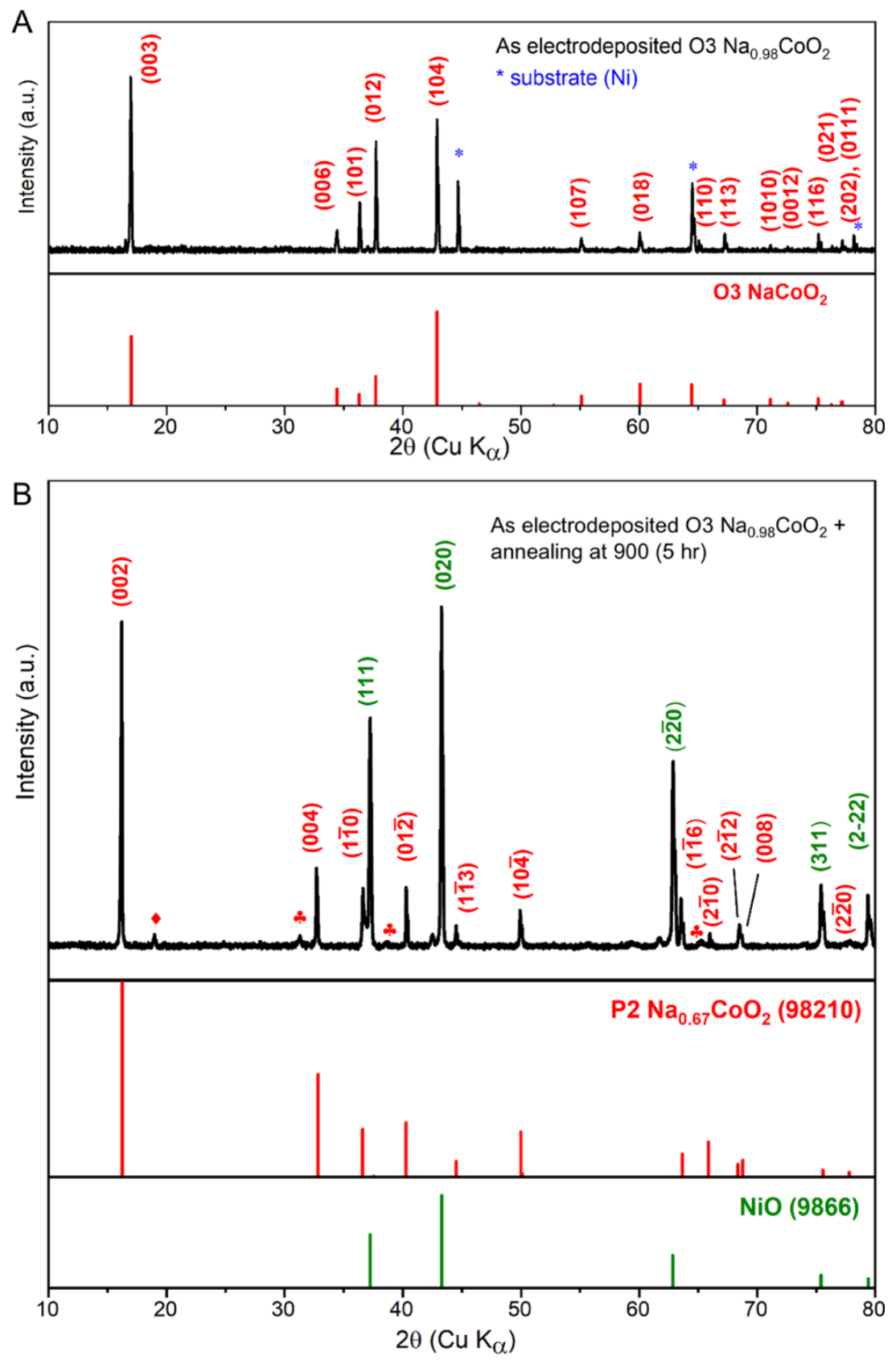

Fig. S5. Thermal conversion of as electrodeposited $\mathrm{O} 3 \mathrm{Na}_{0.98} \mathrm{CoO}_{2}(\mathrm{~A})$ to $\mathrm{P} 2 \mathrm{Na}_{0.67} \mathrm{CoO}_{2}(\mathrm{~B})$. After annealing the electrodeposit at $900^{\circ} \mathrm{C}$ for $5 \mathrm{hr}$ and subsequent quenching, the sample shows full conversion of the $\mathrm{O} 3$ phase to the hexagonal P2 phase with the nickel substrate getting oxidized to $\mathrm{NiO}$. The P2 polytype is indexed as hexagonal phase with a space group P63/mmc (ICSD collection code 98210 ) with parameters $a=2.833 \AA, b=2.833 \AA, c=10.909 \AA$. Small peaks of $\mathrm{Co}_{3} \mathrm{O}_{4}$ (marked in ) are also observed along with possible superstructure reflections (marked in $\diamond)$. 

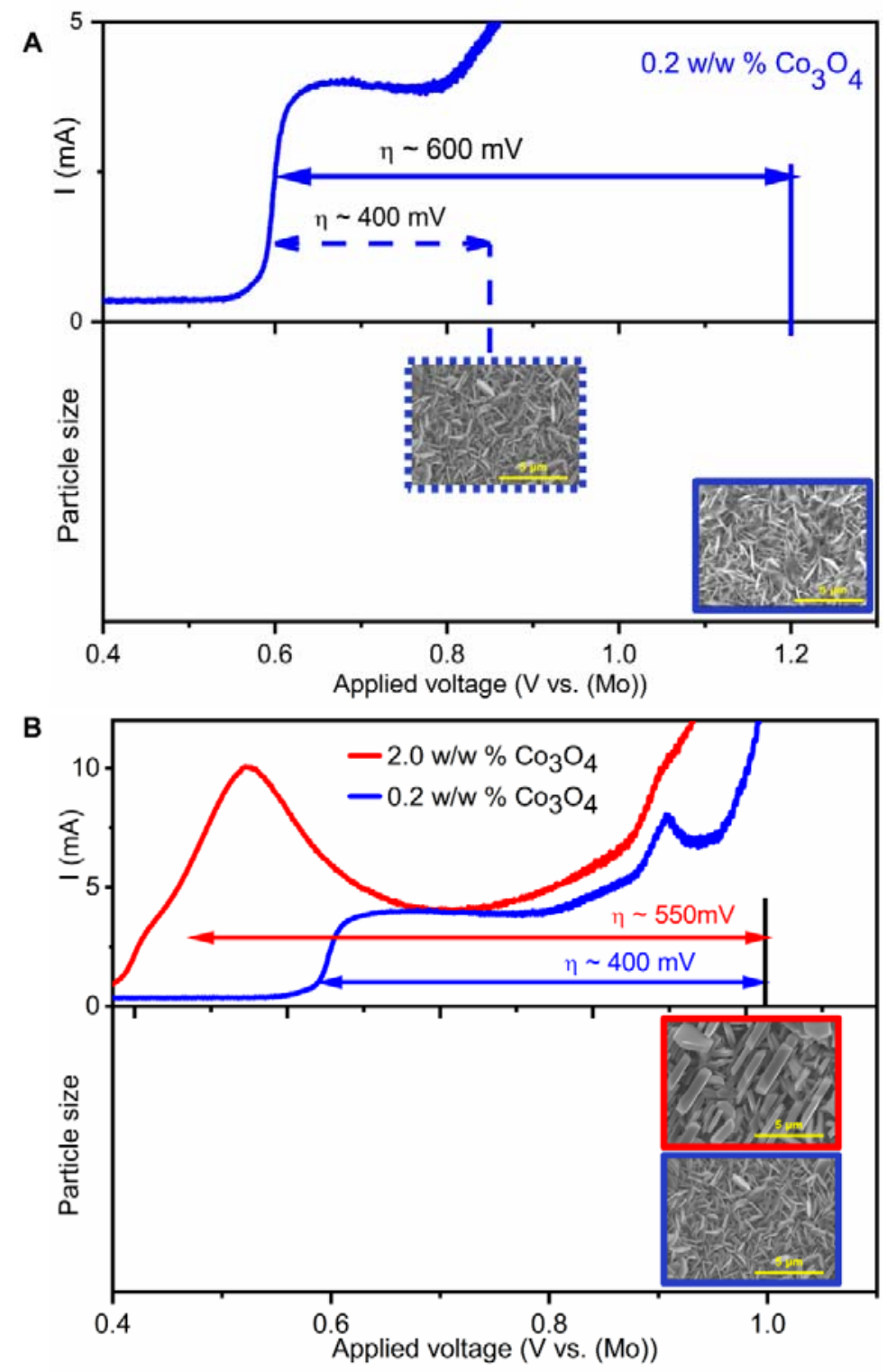

Fig. S6. Effect of deposition condition and resulting morphology in Na-Co-O system. Fig. S6A indicates the effect of deposition potential on morphology of electrodeposits $0.2 \mathrm{w} / \mathrm{w} \% \mathrm{Co}_{3} \mathrm{O}_{4}$ for different applied overpotentials of $400 \mathrm{mV}$ and $600 \mathrm{mV}$. Fig. S6B shows morphology of electrodeposits plated at $550 \mathrm{mV}\left(2.0 \mathrm{w} / \mathrm{w} \% \mathrm{Co}_{3} \mathrm{O}_{4}\right)$ indicate and $0.2 \mathrm{w} / \mathrm{w} \%$ at an applied overpotential of $400 \mathrm{mV}$ for $0.2 \mathrm{w} / \mathrm{w} \% \mathrm{Co}_{3} \mathrm{O}_{4}$ for an applied voltage of $1.0 \mathrm{~V}$ vs. Mo. The morphology shows vertically oriented platelets with $\mathrm{Na}$ ion conducting (110) facets parallel to the substrate. 


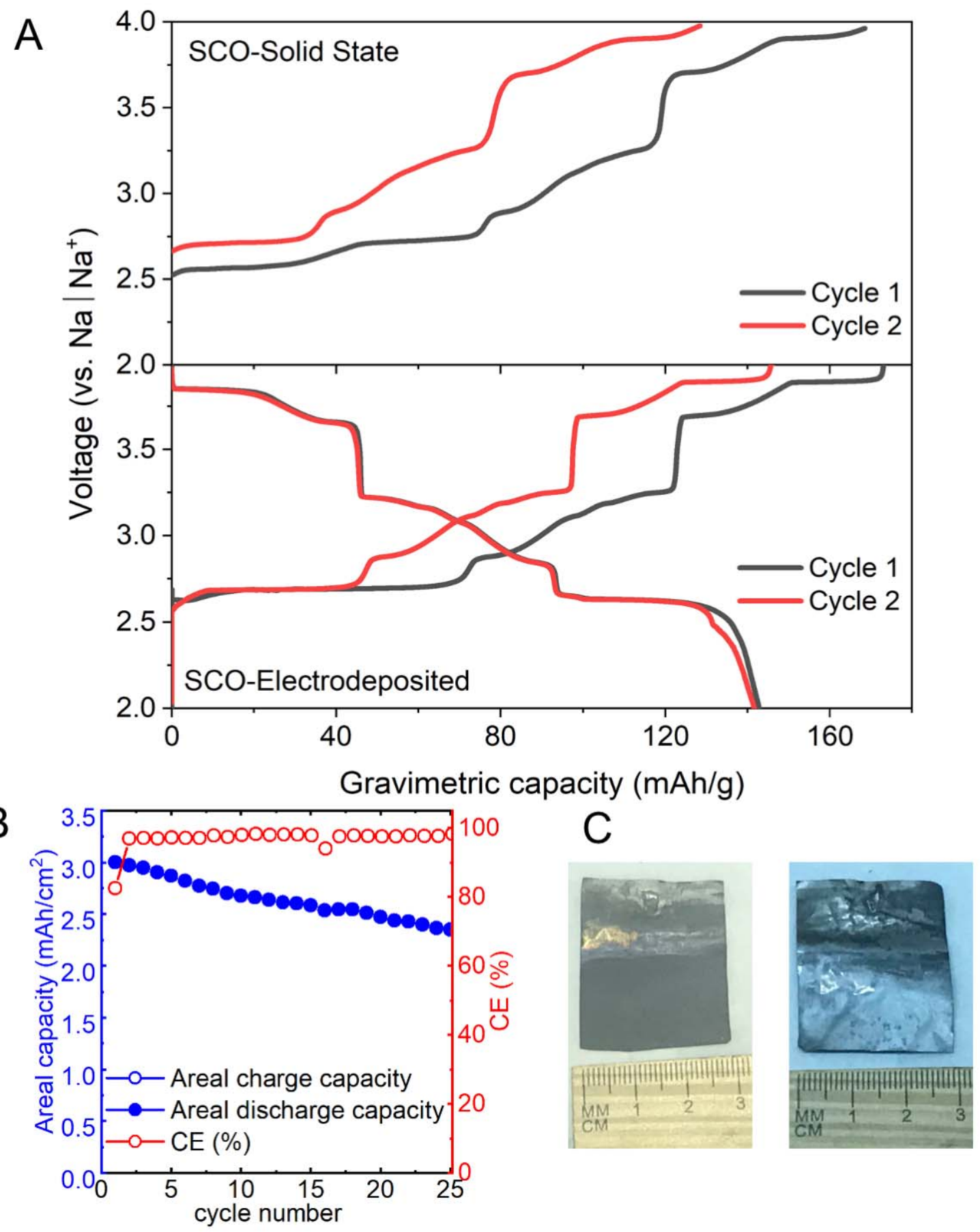

Fig. S7. Sodium intercalation and deintercalation profiles for electrodeposited $\mathrm{O} 3 \mathrm{Na}_{0.98} \mathrm{CoO}_{2}$ and solid state synthesized $\mathrm{O} 3 \mathrm{NaCoO}_{2}$. Fig. S7A indicates the comparison of electrochemical performance in the first two cycles for electrodeposited $\mathrm{O} 3 \mathrm{Na}_{0.98} \mathrm{CoO}_{2}$ (voltage range : 2.0-4.0, at a rate of $\mathrm{C} / 10$, loading : $21.0 \mathrm{mg} / \mathrm{cm}^{2}$, charge discharge current: $0.195 \mathrm{~mA} / \mathrm{cm}^{2}$, areal capacity $\sim 3 \mathrm{mAh} / \mathrm{cm}^{2}$ ) and solid state synthesized $\mathrm{O} 3 \mathrm{NaCoO}_{2}$ (voltage range : 2.0-4.0, at a rate of $\mathrm{C} / 20$, 
charge discharge current: $12 \mathrm{~mA} / \mathrm{g}$ ) (adapted from Ref:(28)). Fig. S7B demonstrates preliminary data on the cyclability and coulombic efficiency of extremely high-loading $\left(21.0 \mathrm{mg} / \mathrm{cm}^{2}\right)$ electrodeposited cathodes photographs of electrodeposited $\mathrm{O} 3 \mathrm{Na}_{0.98} \mathrm{CoO}_{2}$. Fig. S7C shows photographs of electrodeposited $\mathrm{O} 3 \mathrm{Na}_{0.98} \mathrm{CoO}_{2}$. 


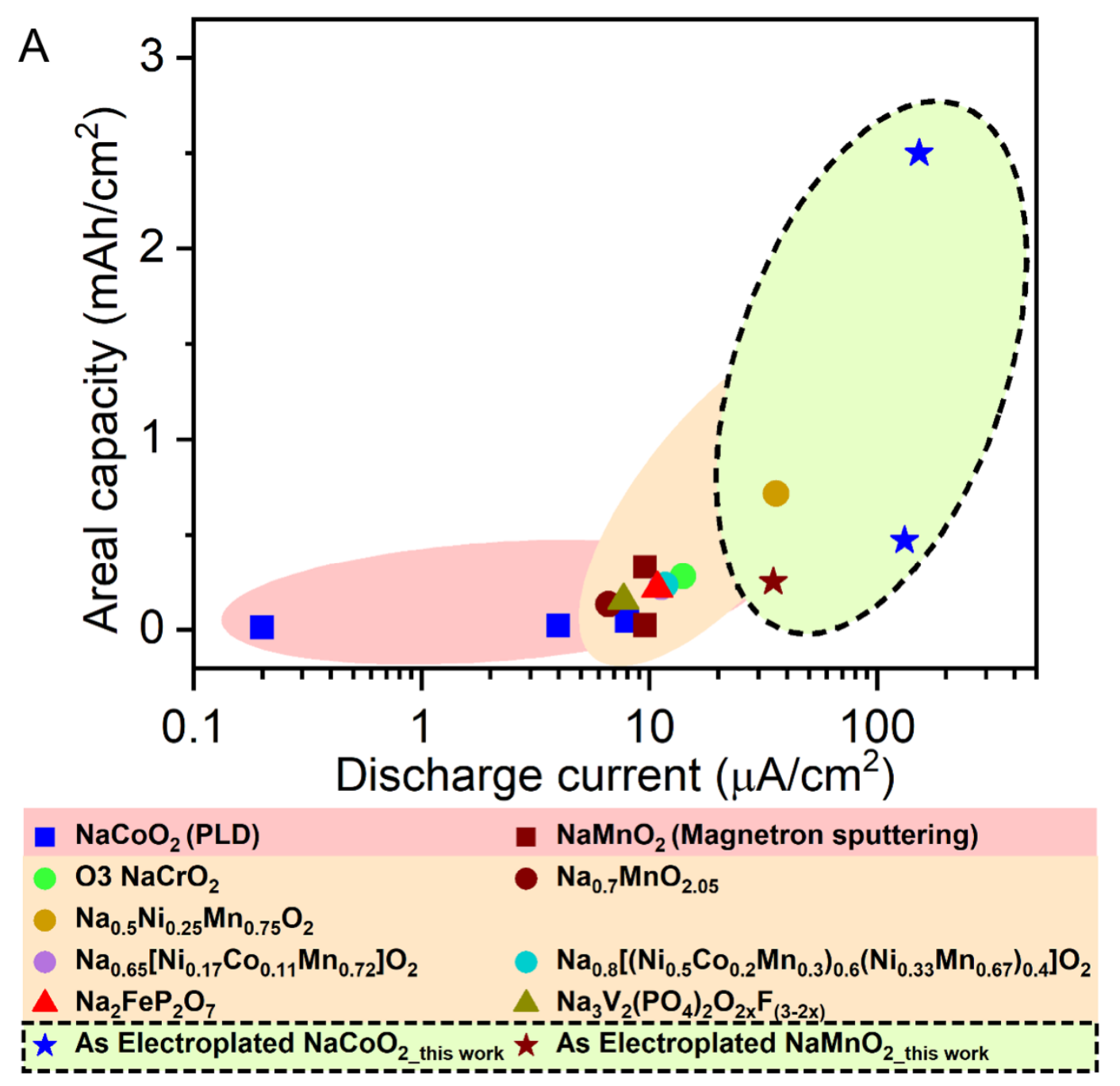

Fig. S8A. A comparison of areal capacity and discharge current of our systems with the existing literature. 
Table S5. A comparison of as electrodeposited cathodes with published examples.

\begin{tabular}{|c|c|c|c|c|c|c|c|}
\hline Electrode material & $\begin{array}{l}\text { Loading } \\
\left(\mathrm{mg} / \mathrm{cm}^{2}\right)\end{array}$ & Electrolyte & Rate & $\begin{array}{l}\text { Voltage } \\
\text { Range } \\
\text { (V vs Na) }\end{array}$ & $\begin{array}{c}\text { Areal } \\
\text { capacity } \\
\left(\mathrm{mAh} / \mathrm{cm}^{2}\right)\end{array}$ & $\begin{array}{c}\text { Discharge } \\
\text { Current } \\
(\mathrm{C} / 10) \\
\mu \mathrm{A} / \mathrm{cm}^{2}\end{array}$ & Reference \\
\hline
\end{tabular}

Examples of $\mathrm{Na}$ cathodes grown by solid state synthesis

\begin{tabular}{|c|c|c|c|c|c|c|c|}
\hline $\mathrm{O} 3 \mathrm{NaCrO}_{2}$ & 3.5 & $\begin{array}{c}0.5 \mathrm{M} \\
\mathrm{NaPF}_{6} \text { in } \\
1: 1 \mathrm{EC}: \mathrm{PC}\end{array}$ & $0.1 \mathrm{C}$ & $2.0-4.0$ & 0.28 & 14.1 & (33) \\
\hline $\mathrm{Na}_{0.7} \mathrm{MnO}_{2.05}$ & 1.0 & $\begin{array}{c}1 \mathrm{M} \mathrm{NaClO}_{4} \\
\text { in } 1: 1 \\
\text { EC:DMC }\end{array}$ & $0.1 \mathrm{~A} / \mathrm{g}$ & $1.8-4.4$ & 0.13 & 6.6 & (34) \\
\hline $\mathrm{Na}_{0.5} \mathrm{Ni}_{0.25} \mathrm{Mn}_{0.75} \mathrm{O}_{2}$ & 4.1 & $\begin{array}{c}1 \mathrm{M} \mathrm{NaPF}_{6} \\
\text { in } 1: 1 \mathrm{EC}: \\
\mathrm{PC}\end{array}$ & $0.5 \mathrm{C}$ & $1.5-4.4$ & 0.72 & 35.9 & (35) \\
\hline $\begin{array}{c}\mathrm{Na}_{0.65}\left[\mathrm{Ni}_{0.17} \mathrm{Co}_{0.11} \mathrm{Mn}_{0.72}\right] \\
\mathrm{O}_{z}\end{array}$ & 1.5 & $\begin{array}{c}0.5 \mathrm{M} \\
\mathrm{NaPF}_{6} \text { in } \\
98: 2 \\
\mathrm{PC}: \mathrm{FEC}\end{array}$ & $\begin{array}{c}12 \\
\mathrm{~mA} / \mathrm{g}\end{array}$ & $1.5-4.3$ & 0.22 & 11.3 & (36) \\
\hline $\begin{array}{c}\mathrm{Na}_{0.8}\left[\left(\mathrm{Ni}_{0.5} \mathrm{Co}_{0.2} \mathrm{Mn}_{0.3}\right)_{0.6}\right. \\
\left.\quad\left(\mathrm{Ni}_{0.33} \mathrm{Mn}_{0.67}\right)_{0.4}\right] \mathrm{O}_{2}\end{array}$ & 2.0 & $\begin{array}{c}2 \mathrm{M} \mathrm{NaClO}_{4} \\
\text { in } 95: 5 \\
\mathrm{PC}: F E C\end{array}$ & $0.1 \mathrm{C}$ & $1.5-4.0$ & 0.23 & 11.7 & $(37)$ \\
\hline $\mathrm{Na}_{2} \mathrm{FeP}_{2} \mathrm{O}_{7}$ & 3.0 & $\begin{array}{c}1 \mathrm{M} \mathrm{NaClO}_{4} \\
\text { in } \mathrm{PC}\end{array}$ & $0.1 \mathrm{C}$ & $2.0-4.0$ & 0.22 & 10.8 & $(38)$ \\
\hline $\mathrm{Na}_{3} \mathrm{~V}_{2}\left(\mathrm{PO}_{4}\right)_{2} \mathrm{O}_{2 x} \mathrm{~F}_{(3-2 \mathrm{x})}$ & 1.5 & $\begin{array}{c}1 \mathrm{M} \mathrm{NaPF}_{6} \\
\text { in } 1: 1 \\
\mathrm{EC}: \mathrm{PC}\end{array}$ & $0.1 \mathrm{C}$ & $2.0-4.3$ & 0.15 & 7.7 & (39) \\
\hline
\end{tabular}

Past work on directly grown sodium cathodes

\begin{tabular}{|c|c|c|c|c|c|}
\hline $\begin{array}{c}\mathrm{NaCoO}_{2} \text { (pulsed laser } \\
\text { deposition) }\end{array}$ & $\beta$ "-alumina & $2.0-3.8$ & 0.046 & 8.0 & $(40)$ \\
\hline $\begin{array}{c}\mathrm{NaCoO}_{2} \text { (pulsed laser } \\
\text { deposition) }\end{array}$ & $\beta$ "-alumina & $2.0-3.8$ & $0.01-.02$ & $4.0-0.2$ & (41) \\
\hline $\begin{array}{c}\mathrm{NaMnO}_{2}(\mathrm{RF} \\
\text { magnetron sputtering) }\end{array}$ & $\begin{array}{c}1 \mathrm{M} \mathrm{NaClO} 4 \\
\text { dissolved in } \\
\mathrm{PC} / \mathrm{EC} / \mathrm{DM} \\
\mathrm{E} 15 / 15 / 70 \\
\text { wt\% }\end{array}$ & $2.0-3.5$ & $0.022-.33$ & 9.6 & (42) \\
\hline
\end{tabular}

Direct electrochemically grown sodium transition metal oxide cathodes

\begin{tabular}{|c|c|c|c|c|c|c|c|}
\hline $\begin{array}{l}\text { As electrodeposited } \\
\qquad 3 \mathrm{NaCoO}_{2}\end{array}$ & 21.0 & $\begin{array}{c}1 \mathrm{M} \mathrm{NaClO}_{4} \\
\text { in PC:FEC } \\
98: 2\end{array}$ & $0.1 \mathrm{C}$ & $2.0-4.0$ & 2.5 & 195 & This work \\
\hline $\begin{array}{l}\text { As electrodeposited } \\
\qquad 3 \mathrm{NaCoO}_{2}\end{array}$ & 8.0 & $\begin{array}{c}1 \mathrm{M} \mathrm{NaClO}_{4} \\
\text { in PC:FEC } \\
98: 2\end{array}$ & $0.1 \mathrm{C}$ & $2.0-3.8$ & 0.49 & 153 & This work \\
\hline $\begin{array}{l}\text { As electrodeposited } \\
\text { O'3 } \mathrm{NaMnO}_{2}\end{array}$ & 1.4 & $\begin{array}{c}1 \mathrm{M} \mathrm{NaClO}_{4} \\
\mathrm{PC}: \mathrm{FEC} \\
98: 2\end{array}$ & $0.1 \mathrm{C}$ & $2.0-3.8$ & 0.25 & 37 & This work \\
\hline
\end{tabular}


A

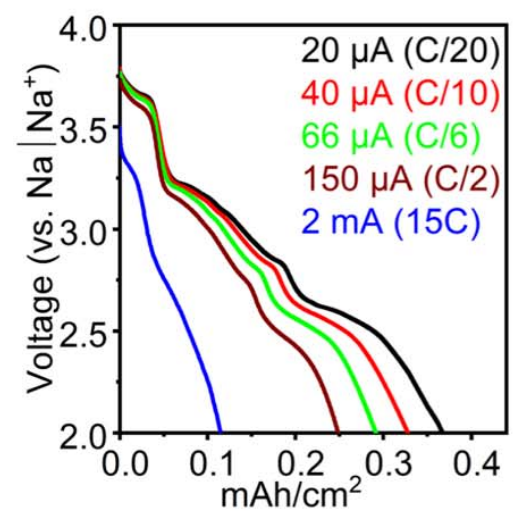

$\mathrm{Bi}$

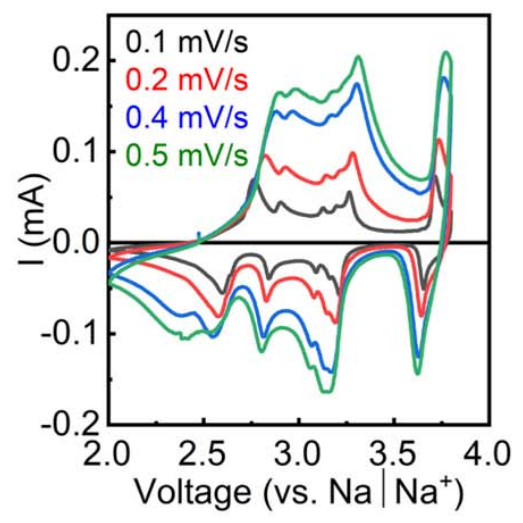

Bii

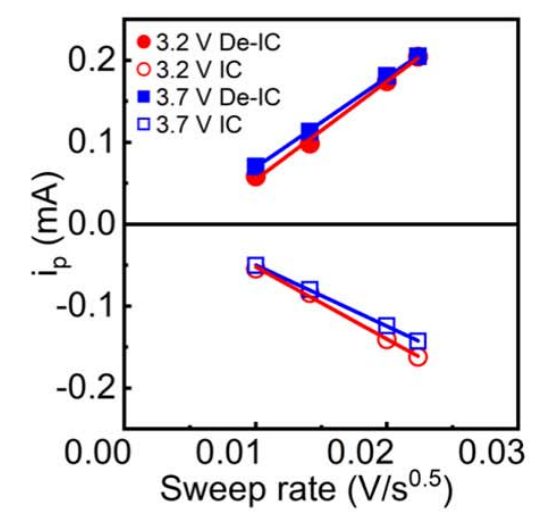

Fig. S9. Chemical diffusion coefficient and rate capability of as-electrodeposited SCO. Fig. S9A shows the discharge voltage profiles for as electrodeposited SCO at discharge currents of $20 \mu \mathrm{A}$ (C/20), $40 \mu \mathrm{A}(\mathrm{C} / 10), 66 \mu \mathrm{A}(\mathrm{C} / 6), 0.15 \mathrm{~mA}(\mathrm{C} / 2)$, and $2.0 \mathrm{~mA}(15 \mathrm{C})$ showing discharge capacity of $0.37,0.33,0.29,0.25$ and $0.11 \mathrm{mAh} / \mathrm{cm}^{2}$ for an area of $1.13 \mathrm{~cm}^{2}$ and loading of $3.94 \mathrm{mgcm}^{-2}$. Fig. S9Bi shows the CV plots for sodium half-cell at varying scan rates of $0.1,0.2,0.4$, and 0.5 $\mathrm{mV} / \mathrm{s}$. The deintercalation/intercalation peak currents for the couple at $3.2 \mathrm{~V}$ and $3.7 \mathrm{~V}$ are chosen for $D_{\mathrm{Na}+}$ analysis in Fig. S9Bii. $D_{\mathrm{Na}^{+}}$is found to be $1.03^{*} 10^{-12} \mathrm{~cm}^{2} \mathrm{~s}^{-1}$ for a loading of $7.11 \mathrm{mg} / \mathrm{cm}^{2}$ and thickness of $20 \mu \mathrm{m}$. Calculation is based on the reversible redox using the Randles-Sevcik equation : $i_{p}=2.69 \times 10^{5} n^{3 / 2} A^{1 / 2} \mathrm{Cv}^{1 / 2}$ where $i_{p}=$ current maximum in $A, n=$ number of electrons transferred in the redox event, $A=$ electrode area in $\mathrm{cm}^{2}, D=$ diffusion coefficient in $\mathrm{cm}^{2} / \mathrm{s}, \mathrm{C}=$ concentration in $\mathrm{mol} / \mathrm{cm}^{3}, \mathrm{v}=$ scan rate in $\mathrm{V} / \mathrm{s}$. 

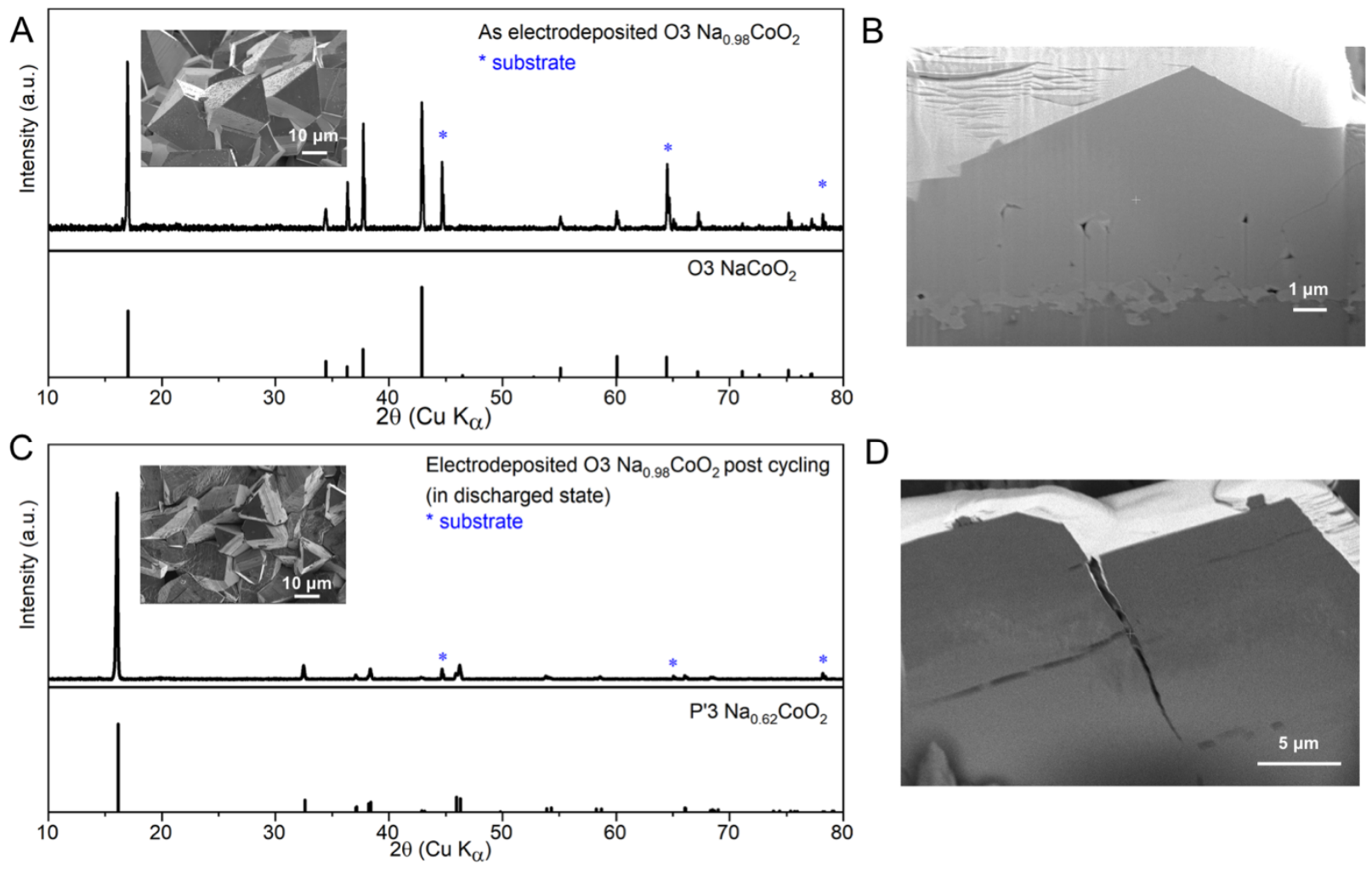

Fig. S10. Electrode degradation pathways of electrodeposited $\mathrm{O} 3 \mathrm{Na}_{0.98} \mathrm{CoO}_{2}$. Fig. S10A shows the $03 \mathrm{Na}_{0.98} \mathrm{NaCoO}_{2}$ in the as electrodeposited stage (with morphology in inset). Fig. S10B shows the FIB cross section of a crystallite in the as electrodeposited sample (Pt protecting layer on top in white and $\mathrm{NaCoO}_{2}$ crystallite in light grey) without any cracking. $\mathrm{X}$ Ray diffraction (Fig. S10C) of the same sample after 100 cycles in the fully discharged state proves that the 03 phase is fully converted to the P'3 phase after cycling. There is no delamination of the electrodeposited oxide as evident by the post-cycling top view microstructure (Fig.S10B inset), which is similar to the as-deposited microstructure. Cross section by focused ion beam and subsequent scanning electron microscopy imaging exhibits intraparticle cracking in the large crystals $(\sim 20 \mu \mathrm{m})$ of electrodeposited $\mathrm{NaCoO}_{2}$ cathodes due to prolonged cycling induced electrochemical fatigue. 

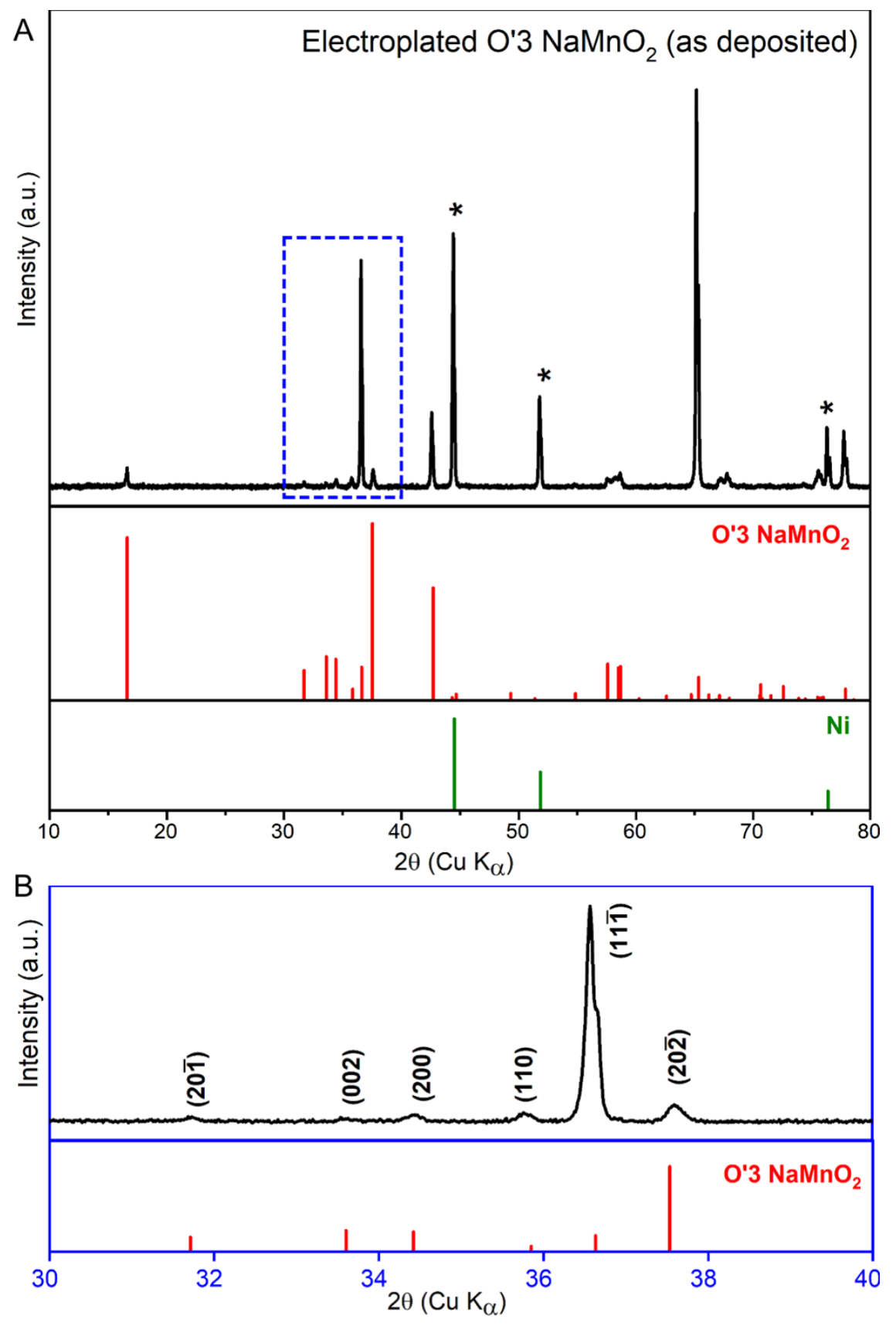

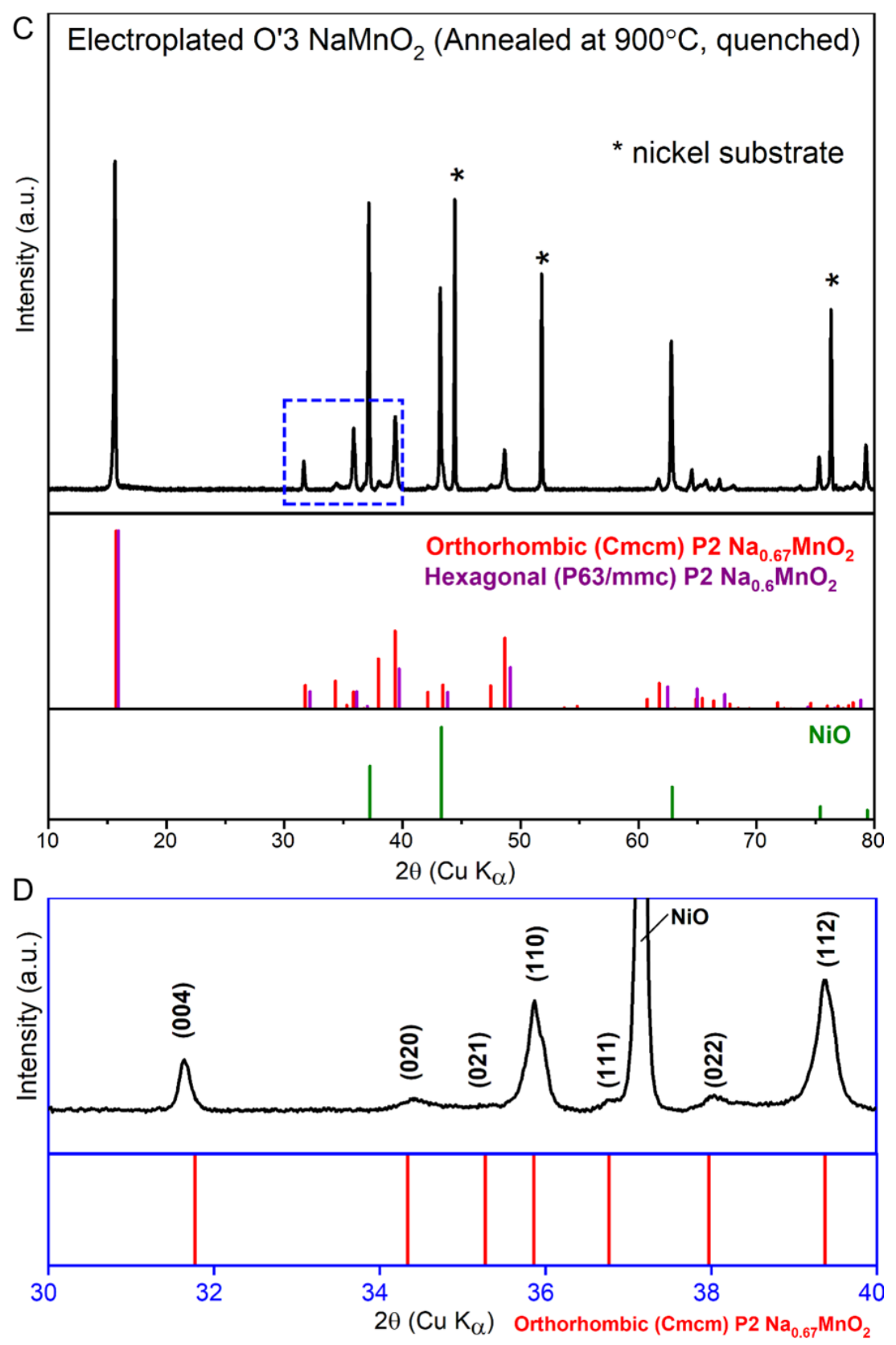

Fig. S11. Thermal conversion of as electrodeposited O'3 $\mathrm{NaMnO}_{2}$ to $\mathrm{P} 2 \mathrm{Na}_{0.67} \mathrm{MnO}_{2}$. $\mathrm{XRD}$ pattern of as electrodeposited $\mathrm{O}^{\prime} 3 \mathrm{NaMnO}_{2}$ [10-80 in (A) and 30-40 in (B), marked by segment in blue] and thermally converted $\mathrm{P} 2 \mathrm{Na}_{x} \mathrm{MnO}_{2}$ [10-80 in (C) and 30-40 in (D), marked by segment in blue]. The as electrodeposited O'3 $\mathrm{NaMnO}_{2}$ is indexed in a monoclinic system with space group $\mathrm{C} 2 / \mathrm{m}$ with unit cell parameters $\left(a=5.6777(6) \AA, b=2.8571(6) \AA, c=5.7597(9) \AA, \beta=113.06^{\circ}\right.$ (Fig. S11A,B). After annealing the electrodeposit at $900^{\circ} \mathrm{C}$ for $6 \mathrm{hr}$ and subsequent quenching, the sample shows full conversion of the monoclinic O'3 phase to the orthorhombic P2 phase with the nickel substrate getting oxidized to $\mathrm{NiO}$. The $\mathrm{P} 2$ polytype is indexed as an orthorhombic phase 
with the space group $\mathrm{Cmcm}$ (04-017-9078) with parameters $\mathrm{a}=5.220 \AA, b=11.257 \AA, c=2.851$ $\AA$. Past studies (43) have shown that depending on the annealing temperature, the P2 phase crystallizes as a mixture of an orthorhombic and hexagonal phase (till $700^{\circ} \mathrm{C}$ ) or a purely orthorhombic phase (at $1000^{\circ} \mathrm{C}$ ), with increase in the annealing temperature resulting in decrease of the hexagonal phase. The hexagonal phase with space group P63/mmc (00-069-0060) and parameters $a=2.869 \AA, b=2.869 \AA, c=11.120 \AA$ is also plotted along with the orthorhombic phase in Fig. S11C to track the presence of each of the phases. Under our experimental conditions, only the orthorhombic phase is isolated (Fig. S11D). 


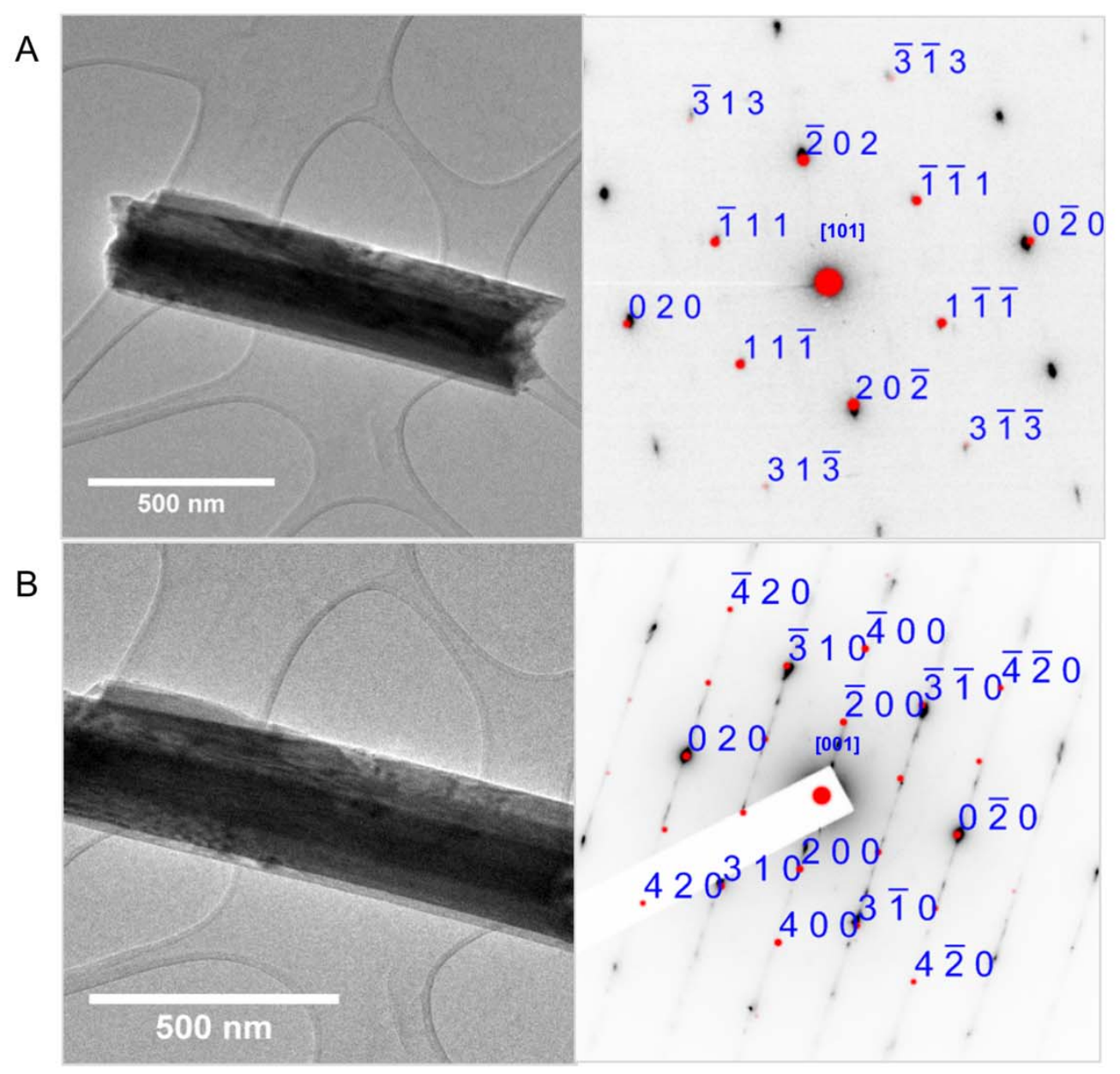

Fig. S12. TEM diffraction analysis of electrodeposited SMO rods. Fig. S12 indicates the indexed diffraction patterns of the rod like elongated structure. Acquired diffraction pattern is indexed (with red dots) in C2/m (ICSD 04-010-1809: $a=5.63 \AA, b=2.86 \AA, c=5.77 \AA, \alpha=90, \beta=112.15, y=$ 90) with a zone axis of [101] A and [001] B. 


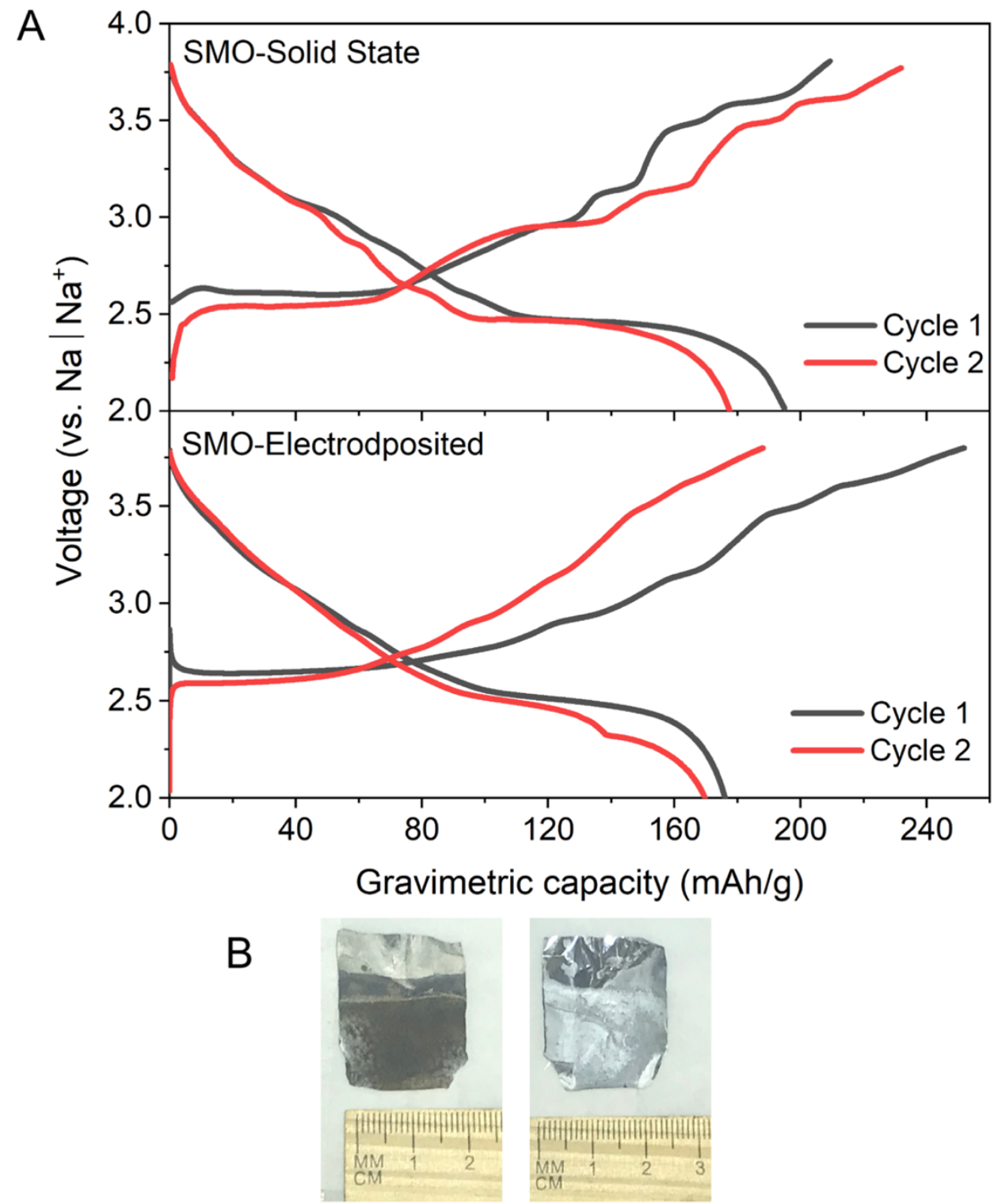

Fig. S13. Sodium intercalation and deintercalation profiles for $\mathrm{O}^{\prime} 3 \mathrm{Na}_{1.3} \mathrm{MnO}_{2+x}$ and solid state synthesized O'3 $\mathrm{NaMnO}_{2}$. Fig. S13A indicates the comparison of electrochemical performance in the first two cycles for as-electrodeposited O'3 $\mathrm{Na}_{1.3} \mathrm{MnO}_{2+x}$ (voltage range : 2.0-3.8 $\mathrm{V}$, loading : $1.41 \mathrm{mg} / \mathrm{cm}^{2}, 35 \mu \mathrm{A} / \mathrm{cm}^{2}$ at a rate of $\mathrm{C} / 10$ ) and solid state synthesized O'3 $\mathrm{NaMnO}_{2}$ (voltage range :2.0-3.8 V, at a rate of $\mathrm{C} / 30,8 \mathrm{~mA} / \mathrm{g}$ ) (Ref:(31)). Fig. S13B shows photographs of electrodeposited O'3 $\mathrm{Na}_{1.3} \mathrm{MnO}_{2+\times}$. 

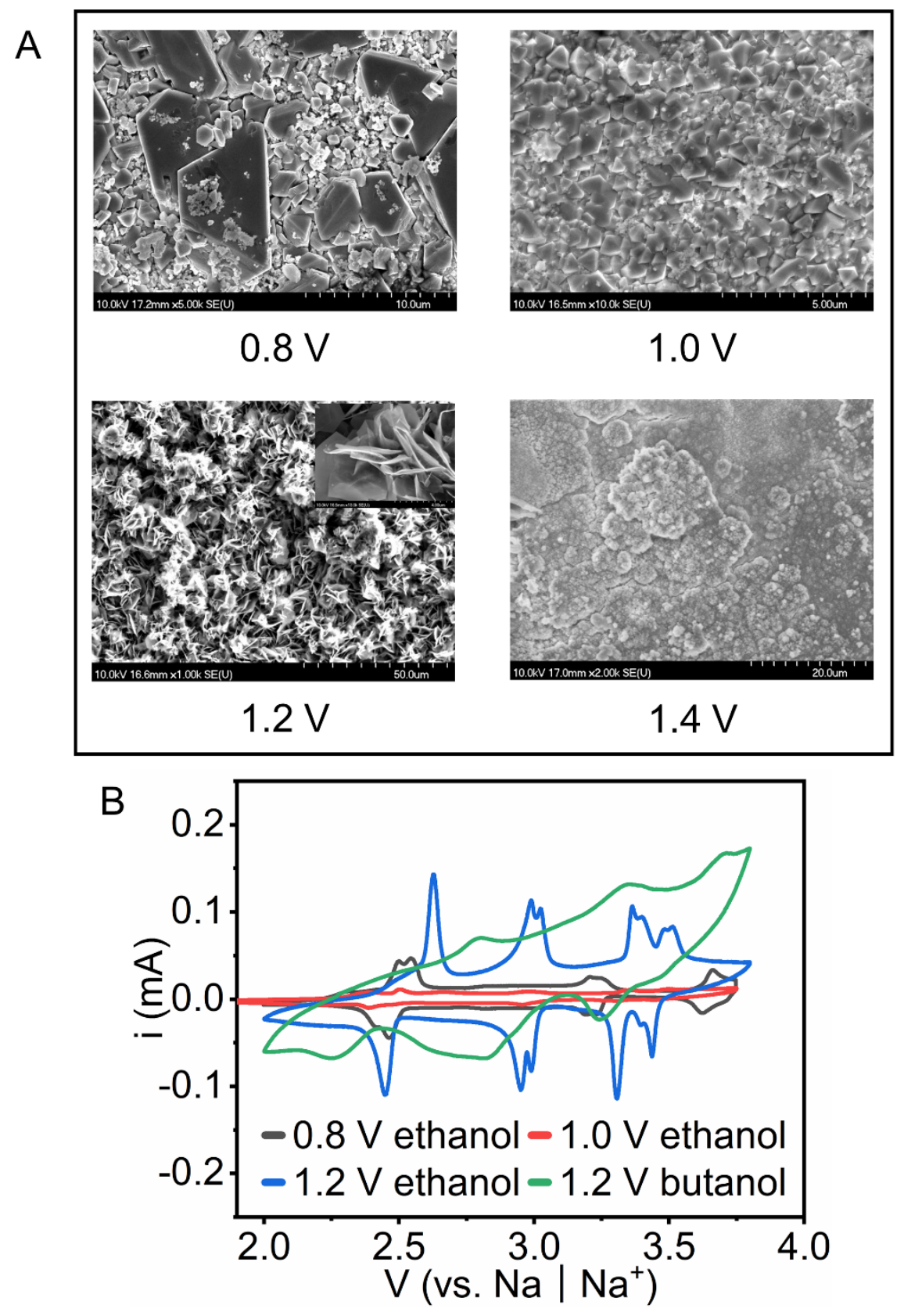

Fig. S14. SNO deposition morphology and role of washing solvent. Fig. S14A shows the top view SEM images for electrodeposits from a molten $\mathrm{NaOH}(160 \mathrm{~g})$ bath containing $\mathrm{Ni}(\mathrm{OH})_{2}(6.4 \mathrm{~g})$ at different applied potentials of $0.8 \mathrm{~V}, 1.0 \mathrm{~V}, 1.2 \mathrm{~V}$ and 1.4 respectively. Duty cycle for all the depositions was $0.25 \mathrm{~s} \mathrm{t}$-on and $8.0 \mathrm{~s}$ t-off. The electrodeposited samples for Fig. S14A are washed with dry ethanol. Fig. S14B shows the coupled effect of different washing solvents on samples electrodeposited at different peak applied voltages. Dry protic polar solvents such as ethanol and butanol fare better for washing in comparison to dry aprotic polar solvents. $\mathrm{NaNiO}_{2}$ is highly 
hygroscopic and undergoes hydrolysis in the presence of even trace amounts of water (44). Attempts at washing in other aprotic polar solvents, such as dry DMSO, dry acetone did not yield any significant dissolution of the $\mathrm{NaOH}$ over a day. We observe that washing in dry ethanol for an electrodeposit at applied voltage $1.2 \mathrm{~V}$ resulted in good adherent deposits which are electrochemically cyclable. 
A

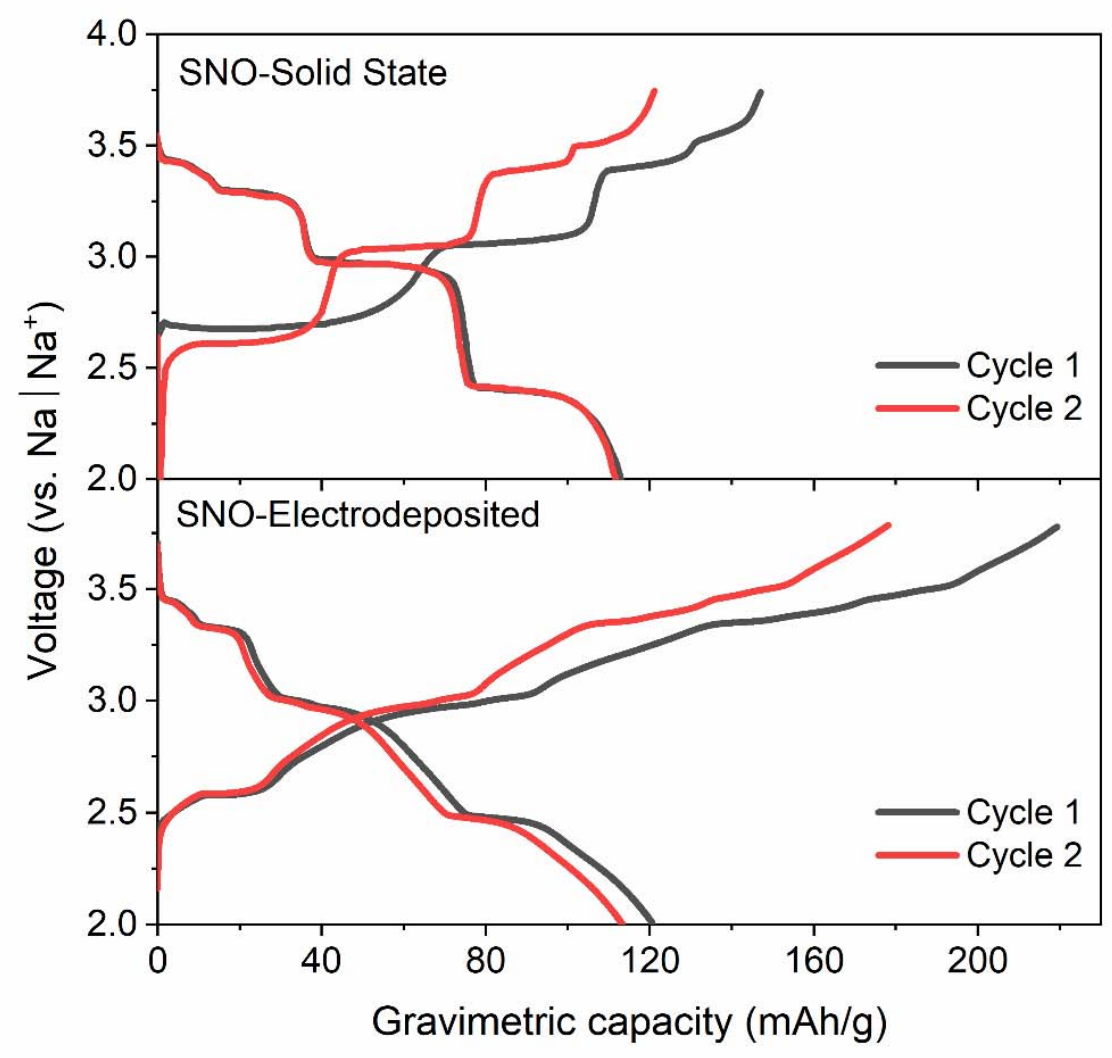

B

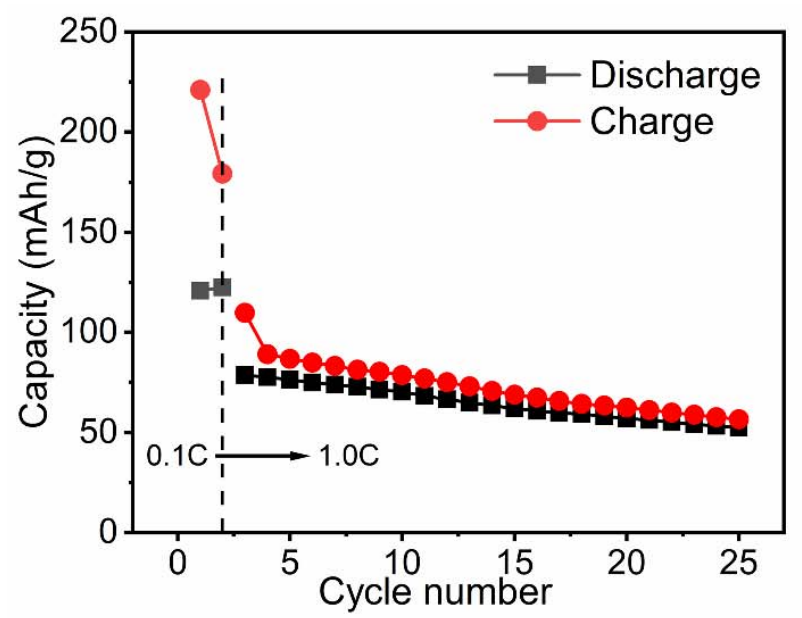

C

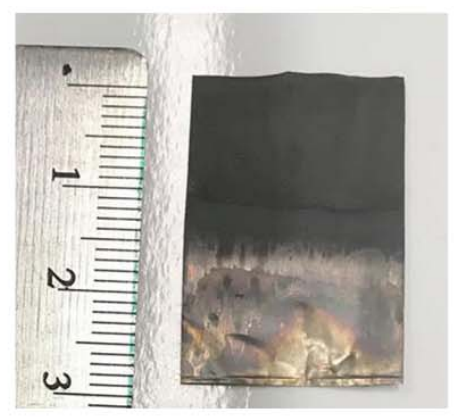

Fig. S15. Cycling of electrodeposited $\mathrm{NaNiO}_{2}$ and solid state synthesized $\mathrm{NaNiO}_{2}$. Fig. S15A indicates the comparison of electrochemical performance in the first two cycles for electrodeposited O'3 $\mathrm{NaNiO}_{2}$ (voltage range : $2.0-3.8 \mathrm{~V}$, loading : $1.1 \mathrm{mg} / \mathrm{cm}^{2}, 20 \mu \mathrm{A} / \mathrm{cm}^{2}$ at a rate of $\mathrm{C} / 10$ ) and solid-state synthesized $\mathrm{O}^{\prime} 3 \mathrm{NaNiO}_{2}$ (Ref: (29)), Fig. S15B shows electrochemical performance of electrodeposited $\mathrm{O}^{\prime} 3 \mathrm{NaNiO}_{2}$ in a half cell configuration vs $\mathrm{Na}$. The first two cycles are conducted at $\mathrm{C} / 10$ and the following cycles at a rate of $1 \mathrm{C}$, Fig. S15C shows photographs of electrodeposited O'3 $\mathrm{NaNiO}_{2}$. 
Supplementary information text. SI2. Attempts at growing thick sodium nickel oxide and associated challenges.

As described in the main text, it is not possible to electrochemically oxidize $\mathrm{Ni}^{2+}$ complex to higher valence without triggering the decomposition of the electrolyte. This results in electrodeposited sodium nickel oxide (SNO) with a low loading $\sim 1.5 \mathrm{mg} / \mathrm{cm}^{2}$. The process has an extremely poor coulombic efficiency e.g., with a $500 \mathrm{mAh}$ charge over an area of $1.5^{\star} 1.5 \mathrm{~cm}^{2}$ results in a $\sim 1.0 \mathrm{mg}$ deposit.

Some possible reasons for the low loading and experiments conducted to mitigate the challenges are described below:

a) Possible chemical instability of $\mathrm{NaNiO}_{2}$ in molten $\mathrm{NaOH}$ : Experiments were conducted in three separate basicity: 1) $\mathrm{NaOH}\left(350^{\circ} \mathrm{C}\right)$, 2) $\left.\mathrm{NaOH}-\mathrm{CsOH}(120 \mathrm{~g}-40 \mathrm{~g})\left(350^{\circ} \mathrm{C}\right), 3\right) \mathrm{NaOH}-\mathrm{KOH}(80 \mathrm{~g}-$ $80 \mathrm{~g})\left(350^{\circ} \mathrm{C}\right)$. However, no significant difference was observed in loading.

b) Precursor (i.e. $\mathrm{Ni}(\mathrm{OH})_{2}$ ) concentration is low: There was no significant improvement in loading by changing $\mathrm{Ni}(\mathrm{OH})_{2}$ concentration from $3.2 \mathrm{~g}, 6.4 \mathrm{~g}$ to $10.0 \mathrm{~g}$.

c) Better precursors for stable complexation: Anion of the precursor play a major role in solubility of the $\mathrm{Ni}^{2+}$ complex. Attempts with $\mathrm{NiNO}_{3}$ as precursor resulted in instantaneous oxidation in the electrolyte.

d) Oxygen evolution is vigorous enough to delaminate the already deposited material: Depositions were carried out at $2.1 \mathrm{~V}(\mathrm{vs} . \mathrm{W})$ and $1.9 \mathrm{~V}$ (vs. $\mathrm{W})$ resulting in rapid $\mathrm{O}_{2}$ evolution yielding a poorly adherent deposit. However, deposits at $0.4 \mathrm{~V}$ overvoltage from the knee voltage i.e. from where the $\mathrm{O}_{2}$ evolution start (i.e. at $1.2 \mathrm{~V}$ ), always give adherent deposits with good loading. Current observed was in the range of $300-350 \mathrm{~mA} / \mathrm{cm}^{2}$. Key is to evolve oxygen slowly near the electrode electrolyte interface and have enough $\mathrm{Ni}^{2+}$ complexed near the interface to aid the deposition.

Key bottleneck for advancing the technology for $\mathrm{NaNiO}_{2}$ is the limitation imposed by the electrochemical stability window of the molten $\mathrm{NaOH}$. We are looking at ways to expand the electrochemical potential window of molten hydroxides to solve this. 
A

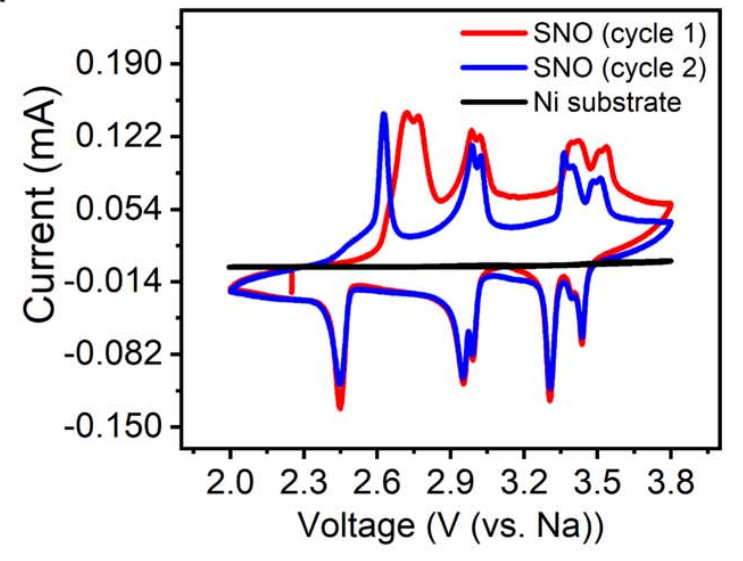

B

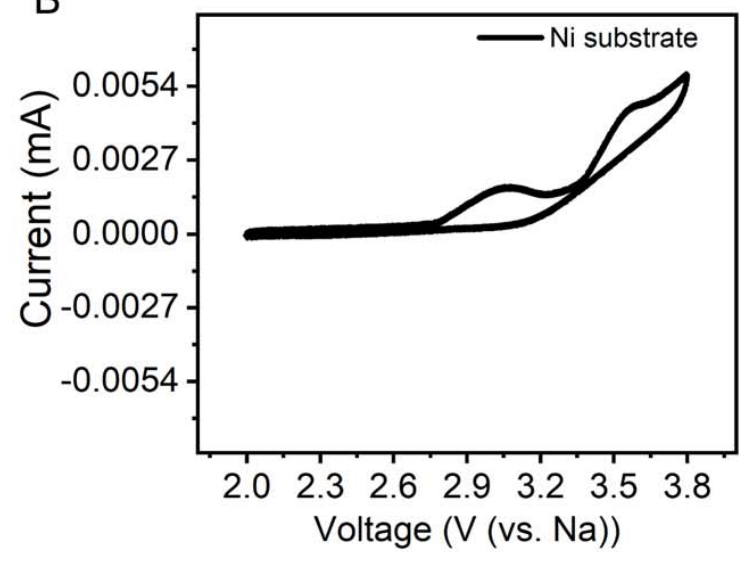

Fig. S16. Electrochemical stability of nickel substrate in Na half-cell. Fig. S16A. CV experiments with a bare nickel foil of the same geometric area as that of the electrodeposited SNO sample, cycled in a Na half-cell within the same potential range using the same electrolyte (1.0 $\mathrm{M} \mathrm{NaClO}_{4}$ in PC: FEC $98: 2$ by vol). The cyclic voltammetry of bare nickel has been overlayed on the cyclic voltammetry of electrodeposited $\mathrm{NaNiO}_{2}$ to show the near zero contribution of the bare nickel to the electrolyte decomposition/ nickel dissolution. Nickel is electrochemically stable in the voltage window (2.0-3.8 V vs. $\mathrm{Na}$ ref) for the electrolyte concerned. Fig. S16B. Magnified profile of bare nickel substrate during $\mathrm{CV}$ in the half cell.

Please note that our electrodeposited cathodes can be grown on battery grade aluminum foil, stainless steel foil and battery grade nickel foil and are compatible of the other $\mathrm{Na}$ ion battery electrolytes such as $0.6 \mathrm{M} \mathrm{NaPF}_{6}$ in EC:PC (1:1 by vol). 
Table S6. Attempts at growing thick sodium iron oxide and associated challenges.

Table S6A. Role of $\mathrm{KOH}$ to produce thicker deposits.

\begin{tabular}{c|c|c|c|c}
\hline \hline $\begin{array}{c}\mathrm{NaOH} \\
(\mathrm{g})\end{array}$ & $\begin{array}{c}\mathrm{KOH} \\
(\mathrm{g})\end{array}$ & $\begin{array}{c}\mathrm{CsOH} \\
(\mathrm{g})\end{array}$ & $\begin{array}{c}\mathrm{NaOH} / \mathrm{KOH} \\
\text { molar ratio }\end{array}$ & $\begin{array}{c}\text { Phase } \\
\text { assemblage }\end{array}$ \\
\hline \hline 160 & 0 & 0 & Inf & No plating \\
\hline 160 & 0 & 0 & $\mathrm{Inf}$ & No plating \\
\hline 120 & 40 & 0 & 3 & $\begin{array}{c}\mathrm{KFeO}_{2}+\alpha \\
\mathrm{NaFeO}_{2}\end{array}$ \\
\hline 80 & 80 & 0 & 1 & $\mathrm{KFeO}_{2}$ \\
\hline 20 & 140 & 0 & $1 / 7$ & $\mathrm{KFeO}_{2}$ \\
\hline 20 & 120 & 20 & $1 / 6$ & $\mathrm{KFeO}_{2}$ \\
\hline
\end{tabular}

Table S6B. Replacing $\mathrm{NaOH}$ with equivalent molar chloride and carbonate salts in optimized $\mathrm{NaOH}-\mathrm{CsOH}$ electrolyte.

\begin{tabular}{c|c|c|c|c}
\hline $\mathrm{NaCl}(\mathrm{g})$ & $\mathrm{NaOH}(\mathrm{g})$ & $\mathrm{Na}_{2} \mathrm{CO}_{3}(\mathrm{~g})$ & $\mathrm{CsOH}(\mathrm{g})$ & Observation \\
\hline \hline 0 & 120 & 0 & 40 & Usual (low loading SIO) \\
\hline $28($ eq 160) & 160 & 0 & 0 & Isolating $\mathrm{NaCl}(1: 9 \mathrm{~mol})$ \\
\hline 0 & 120 & 35.3 & 0 & Isolating $\mathrm{Na}_{2} \mathrm{CO}_{3}(1: 9 \mathrm{~mol})$ \\
\hline 0 & 93 & 27 & 40 & Partitioning $\mathrm{Na}$ to $\mathrm{NaOH}$ and \\
$\mathrm{Na}_{2} \mathrm{CO}_{3}$
\end{tabular}



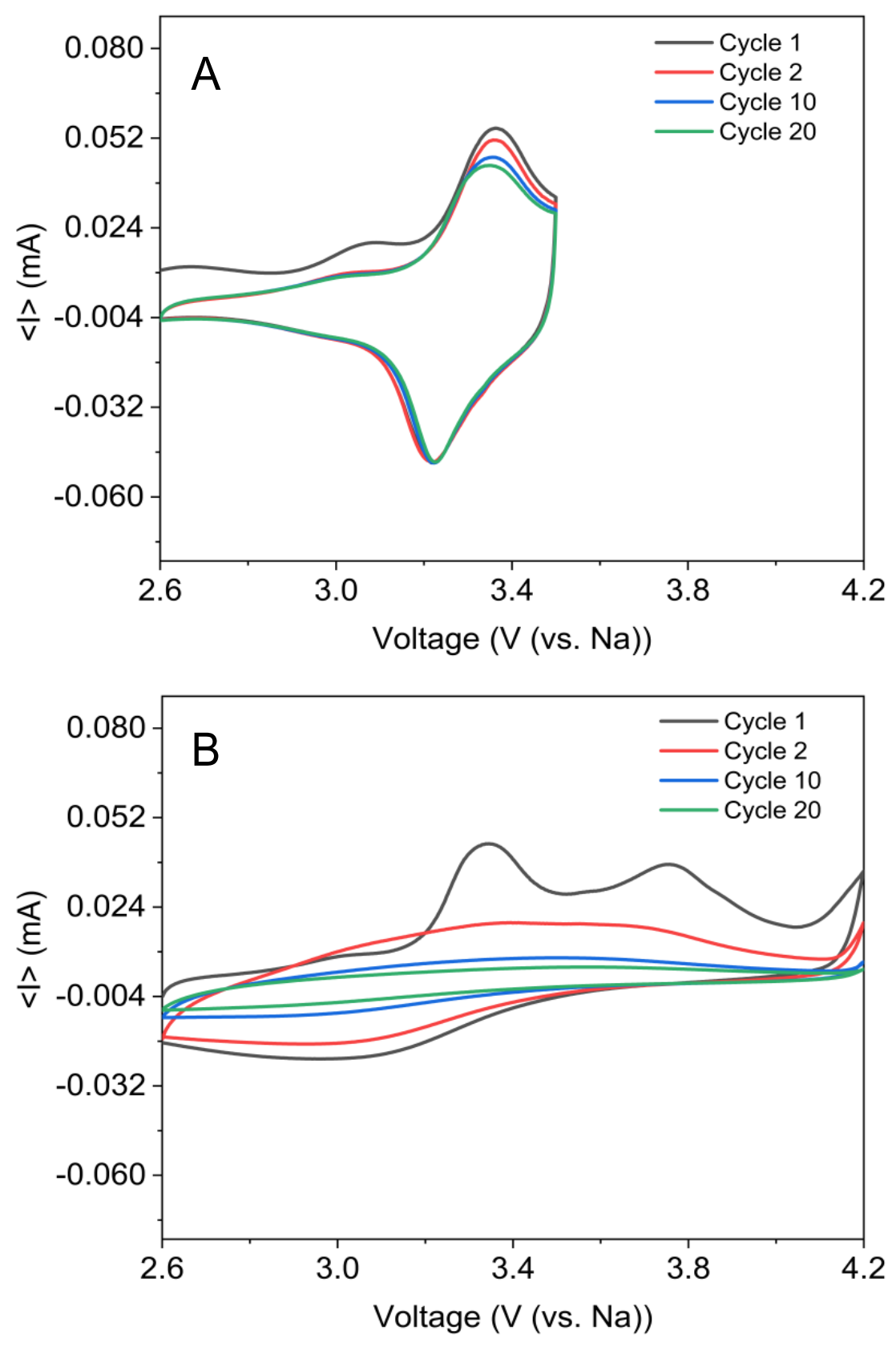

Fig. S17. Role of voltage range on electrochemical reversibility of electrodeposited $\mathrm{Na}_{x} \mathrm{FeO}_{2}$ in a sodium half-cell using $1 \mathrm{M} \mathrm{NaClO}_{4}$ in PC: FEC (98:2 vol:vol) as the electrolyte. Fig. S11A and Fig. S11B indicate $\mathrm{CV}$ of electrodeposited $\mathrm{Na}_{x} \mathrm{FeO}_{2}$ between voltage ranges of 2.6-3.5 $\mathrm{V}$ and 2.6-4.2 $\mathrm{V}$ respectively, at a scan rate of $0.1 \mathrm{mV} / \mathrm{s}$. Electrodeposited $\mathrm{Na}_{x} \mathrm{FeO}_{2}$ can be reversibly cycled between 2.6-3.5 $\mathrm{V}$ but extending the voltage to a higher cut off $4.2 \mathrm{~V}$ leads to poor reversibility. Such irreversible phase transitions leading to capacity fade has also been observed in solid state synthesized $\mathrm{O} 3 \mathrm{NaFeO}_{2}(45)$. 


\section{SI References}

1. H. Zhang, et al., Electroplating lithium transition metal oxides. Sci. Adv. 3, 1-9 (2017).

2. H. Hayashi, S. Yoshizawa, Y. Ito, Studies on oxygen reduction in molten $\mathrm{NaOH}$. Electrochim. Acta 28, 149-153 (1983).

3. W. Ding, J. Gomez-Vidal, A. Bonk, T. Bauer, Molten chloride salts for next generation CSP plants: Electrolytical salt purification for reducing corrosive impurity level. Sol. Energy Mater. Sol. Cells 199, 8-15 (2019).

4. N. J. Gese, "The Electrochemistry of Li-LiCl-Li2O Molten Salt Systems and the Role of Moisture," University of Idaho. (2006).

5. I. Barin, Thermochemical data of pure substances (1997).

6. T. Tsukada, S. Venigalla, J. H. Adair, Low-temperature electrochemical synthesis of ZrO2 films on zirconium substrates: Deposition of thick amorphous films and in situ crystallization on zirconium anode. J. Am. Ceram. Soc. 80, 3187-3192 (1997).

7. E. Andrukaitis, P. W. M. Jacobs, J. W. Lorimer, Vanadium pentoxide electrodes. I. Formation of vanadium pentoxide from anodic electrodeposits. Solid State Ionics 27, 1930 (1988).

8. R. V. Gudavarthy, et al., Epitaxial electrodeposition of chiral CuO films from copper(ii) complexes of malic acid on $\mathrm{Cu}(111)$ and $\mathrm{Cu}(110)$ single crystals. J. Mater. Chem. 21, 6209-6216 (2011).

9. J. A. Koza, J. C. Hill, A. C. Demster, J. A. Switzer, Epitaxial Electrodeposition of Methylammonium Lead lodide Perovskites. Chem. Mater. 28, 399-405 (2016).

10. A. A. Vertegel, E. W. Bohannan, M. G. Shumsky, J. A. Switzer, Epitaxial Electrodeposition of Orthorhombic a-PbO[sub 2] on (100)-Oriented Single Crystal Au. J. Electrochem. Soc. 148, C253 (2001).

11. J. A. Switzer, Electrodeposited ceramic single crystals. Science (80-. ). 284, 293-296 (1999).

12. J. A. Switzer, The n-Silicon/Thallium(III) Oxide Heterojunction Photoelectrochemical Solar Cell. J. Electrochem. Soc. 133, 722-728 (1986).

13. H. M. Kothari, et al., Electrochemical deposition and characterization of $\mathrm{Fe} 3 \mathrm{O} 4$ films produced by the reduction of Fe(III)-triethanolamine. J. Mater. Res. 21, 293-301 (2006).

14. J. A. Koza, Z. He, A. S. Miller, J. A. Switzer, Electrodeposition of crystalline Co 30 4-A catalyst for the oxygen evolution reaction. Chem. Mater. 24, 3567-3573 (2012).

15. T. D. Golden, A. Q. Wang, Anodic Electrodeposition of Cerium Oxide Thin Films. J. Electrochem. Soc. 150, C621 (2003).

16. J. A. Switzer, R. J. Phillips, R. P. Raffaelle, Electrodeposition of Nanoscale Artificially Layered Ceramics. 244-253 (1992).

17. M. Alsabet, M. Grdeń, G. Jerkiewicz, Electrochemical Growth of Surface Oxides on Nickel. Part 3: Formation of $\beta-\mathrm{NiOOH}$ in Relation to the Polarization Potential, Polarization Time, and Temperature. Electrocatalysis 6, 60-71 (2014).

18. G. H. A. Therese, P. V. Kamath, Electrochemical synthesis of metal oxides and hydroxides. Chem. Mater. 12, 1195-1204 (2000).

19. D. Tench, L. F. Warren, Electrodeposition of Conducting Transition Metal Oxide/Hydroxide Films from Aqueous Solution. J. Electrochem. Soc. 130, 869-872 (1983).

20. W. S. Cho, et al., Active electrochemical dissolution of molybdenum and application for room-temperature synthesis of crystallized luminescent calcium molybdate film. J. Am. Ceram. Soc. 80, 765-769 (1997).

21. W. S. Cho, M. Yoshimura, Structure evolution of highly crystallized BaWO4 film prepared by an electrochemical method at room temperature. J. Am. Ceram. Soc. 80, 2199-2204 (1997). 
22. K. S. Han, S. W. Song, M. Yoshimura, Room-temperature fabrication of lithium cobalt oxide thin-film electrodes by lithium hydroxide solution treatment. J. Am. Ceram. Soc. 81, 2465-2468 (1998).

23. D. Gao, Y. Li, X. Lai, J. Bi, D. Lin, Room-temperature synthesis of crystallized LiCoO2 thin films by electrochemical technique. J. Alloys Compd. 509, 697-703 (2011).

24. T. L. Friedman, A. M. Stacy, Electrochemistry in Molten Hydroxides: Synthesis of NaCuO2. J. Solid State Chem. 109, 203-204 (1994).

25. T. N. Nguyen, H. C. Zur Loye, Electrosynthesis in hydroxide melts. J. Cryst. Growth 172, 183-189 (1997).

26. N. S. Chong, N. T. Suen, T. L. Chou, H. Y. Tang, Electrocrystallization and characterization of polymorphic forms of barium metaplumbate. Cryst. Growth Des. 8, 1779-1782 (2008).

27. X. Ma, H. Chen, G. Ceder, Electrochemical Properties of Monoclinic NaMnO2. J. Electrochem. Soc. 158, A1307 (2011).

28. Y. Lei, X. Li, L. Liu, G. Ceder, Synthesis and stoichiometry of different layered sodium cobalt oxides. Chem. Mater. 26, 5288-5296 (2014).

29. P. Vassilaras, X. Ma, X. Li, G. Ceder, Electrochemical Properties of Monoclinic NaNiO2. J. Electrochem. Soc. 160, A207-A211 (2012).

30. E. Lee, et al., New Insights into the Performance Degradation of Fe-Based Layered Oxides in Sodium-Ion Batteries: Instability of Fe3+/Fe4+ Redox in a-NaFeO2. Chem. Mater. 27, 6755-6764 (2015).

31. X. Ma, H. Chen, G. Ceder, Electrochemical properties of monoclinic NaMnO2. J. Electrochem. Soc. 158, 1307-1312 (2011).

32. Y. Lei, X. Li, L. Liu, G. Ceder, Synthesis and Stoichiometry of Di ff erent Layered Sodium Cobalt Oxides. Chem. Mater. 26, 5288-5296 (2014).

33. C.-Y. Yu, et al., NaCrO2 cathode for high-rate sodium-ion batteries. Energy Environ. Sci. 8, 2019-2026 (2015).

34. D. Lu, et al., Polypyrrole-Coated Sodium Manganate Hollow Microspheres as a Superior Cathode for Sodium Ion Batteries. ACS Appl. Mater. Interfaces 11, 15630-15637 (2019).

35. X. J. Pang, et al., Performance enhancement of Sn???Sb???Co alloy film anode for lithium-ion batteries via post electrodissolution treatment. J. Appl. Electrochem. 45, 115$122(2014)$.

36. T.-Y. Yu, J.-Y. Hwang, D. Aurbach, Y.-K. Sun, Microsphere

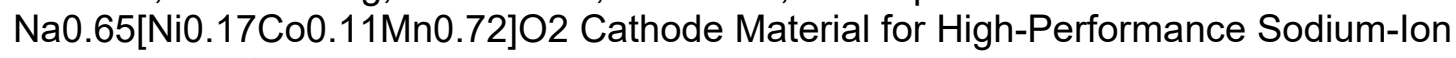
Batteries. ACS Appl. Mater. Interfaces 9, 44534-44541 (2017).

37. C. Chen, et al., Core-Shell Layered Oxide Cathode for High-Performance Sodium-Ion Batteries. ACS Appl. Mater. Interfaces 12, 7144-7152 (2020).

38. P. Barpanda, et al., Na2FeP2O7: A Safe Cathode for Rechargeable Sodium-ion Batteries. Chem. Mater. 25, 3480-3487 (2013).

39. J. Song, B. Xiao, Y. Lin, K. Xu, X. Li, Interphases in Sodium-lon Batteries. 1703082, 1-24 (2018).

40. P. Kehne, et al., Electrochemical Performance of All-Solid-State Sodium-Ion Model Cells with Crystalline $\mathrm{Na} \times \mathrm{CoO} 2$ Thin-Film Cathodes . J. Electrochem. Soc. 166, A5328A5332 (2019).

41. P. Kehne, C. Guhl, L. Alff, R. Hausbrand, P. Komissinskiy, The effect of calcium impurities of $\beta$ "-alumina on the degradation of $\mathrm{NaxCoO} 2$ cathodes in all solid state sodium-ion batteries. Solid State Ionics 341 (2019).

42. L. Baggetto, et al., Sodium manganese oxide thin films as cathodes for Na-ion batteries. ECS Trans. 58, 47-57 (2013).

43. R. Stoyanova, et al., Stabilization of over-stoichiometric Mn4+ in layered Na2/3MnO2. J. Solid State Chem. 183, 1372-1379 (2010). 
44. C. Delmas, Y. Borthomieu, C. Faure, A. Delahaye, M. Figlarz, Nickel hydroxide and derived phases obtained by chimie douce from NaNiO2. Solid State Ionics 32-33, 104111 (1989).

45. N. Yabuuchi, H. Yoshida, S. Komaba, Crystal structures and electrode performance of alpha-NaFeO2 for rechargeable sodium batteries. Electrochemistry 80, 716-719 (2012). 